\title{
Eski Anadolu Türkçesi Dönemine Ait Bir Eser: Aksaraylı Îsâ, Destân-1 İsmâîl [06 Mil Yz A 6823/5]
}

\section{A Literary Work of Old Anatolian Turkish Period: Aksaraylı Îsâ, Destân-I İsmâîl [06 Mil Yz A 6823/5]}

\author{
Türkan KorKMAZ BULUT \\ İstanbul Rumeli University (İstanbul/Turkey) \\ E-mail: turkankorkmaz88@gmail.com
}

\begin{abstract}
Aksaraylı Îsâ lived in the XIVth century around Konya and Aksaray. It is understood from his works that he received a good education and was familiar with religious sciences. Only four of his works have survived today. If the literature is reviewed, new works may be revealed. The subjects he dealt with are about religion and morality. He aimed to popularize Islam and to explain some simple religious information to the public through his works. This study will focus on the story titled Destân-ı İsmâ'il and it is based on the manuscript (06 Mil Yz A 6823/5) in the Ankara National Library. The work has the characteristics of old Anatolian Turkish language. In this study, after literary and language studies, transcription of the text, in-language translation and index of the work will be given and fac-simile of the work will be added at the end of the study.
\end{abstract}

Key Words: Old Anatolian Turkish, Aksaraylı Isa, Destân-1 İsmâ'îl. 


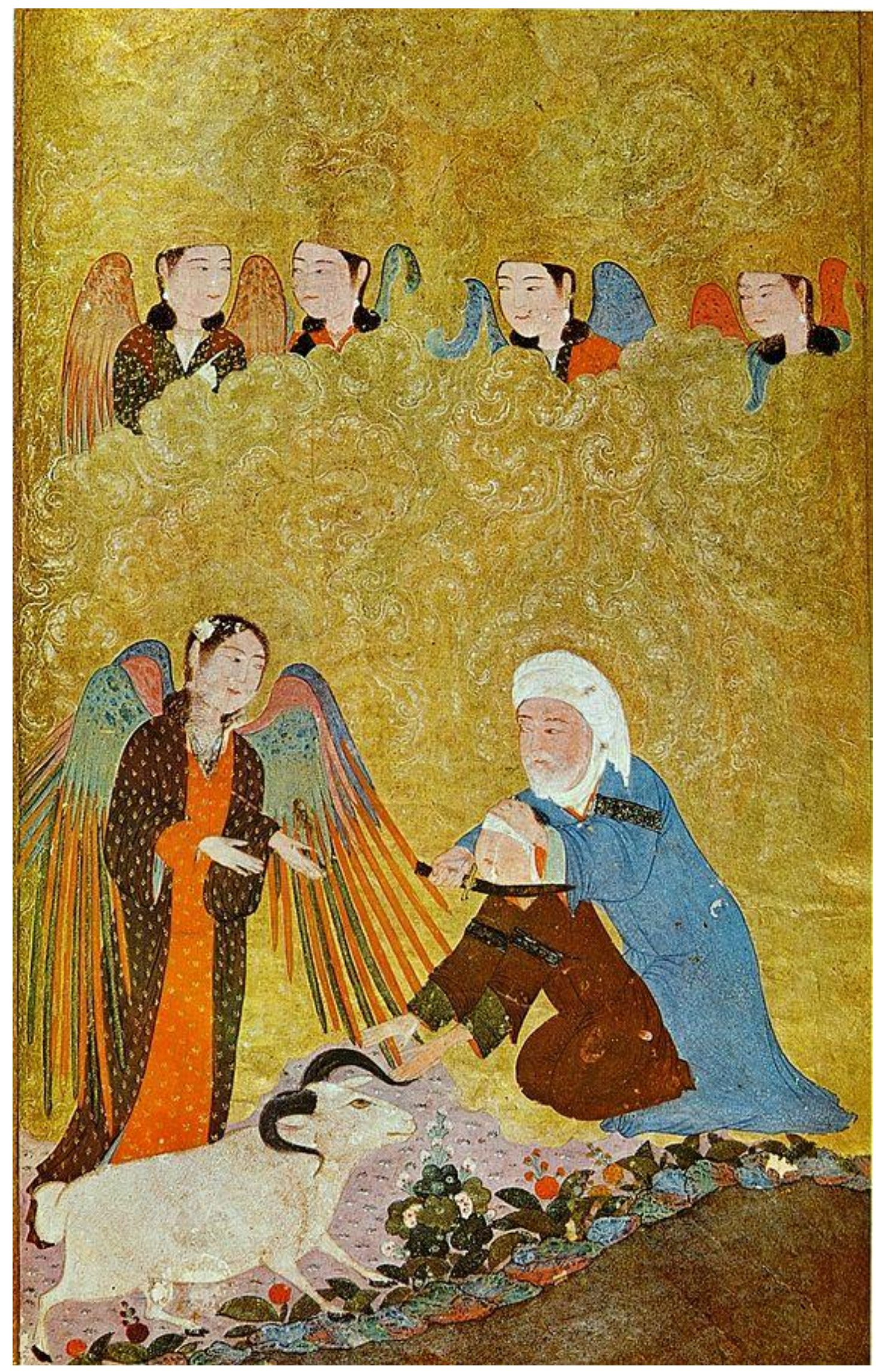

Şiraz'dan bir minyatür [1410-1411] (Gülbenkyan Koleksiyonu, Lizbon) 


\section{Giriş}

İsmail peygamber, Hz. İbrahim'in oğlu ve Kur'an'da adı geçen bir peygamberdir. İsmail kelimesiyle ilgili farklı görüşler olmakla birlikte kelimenin aslı İbranice Yişmâ'êl'dir. Kelime, 'Tanrı işitir' anlamındadır. Tevrat'ta Yişmael kelimesi meleğin: "İşte sen gebesin ve bir oğul doğuracaksın ve onun adını İsmâil koyacaksın çünkü Rab sana olan cefayı işitti." (Tekvin, 16/11) sözünden hareketle İbranicede 'işitmek, bir dilek veya isteği kabul etmek' anlamına gelen şâma fiiline bağlanmaktadır. Tevrat'a göre İsmail, Hz. İbrahim'in Hacer'den ilk ve tek çocuğudur. Çocuğu olmayan Sare, cariyesi Hacer'i eşine vermiş ve İbrahim 86 yaşındayken ilk çocuğu İsmail doğmuştur. Tevrat'a göre İsmail 14 yaşındayken Sare İshak'ı doğurmuştur.

İsmail peygamberin adı, Kur'an'da 12 yerde geçmektedir. Annesi Hacer hakkında Kur'an'da bilgi bulunmamaktadır. Kur'an'a göre İsmail, babası İbrahim'in yaşlılık döneminde ve bir duası sonucunda dünyaya gelmiştir. İsmail, çok küçükken babası tarafından Kâbe'nin bulunduğu yere götürülmüştür. Kur'an'da kurban edilmek istenen çocuğun adı açıkça zikredilmese de İslami literatürde daha çok bu kişinin İsmail olduğuna inanılır. Daha sonra babası ile birlikte Kâbe'nin yapımında çalışmış ve babası tarafından bu kutsal mekânın temiz tutulmasında görevlendirilmiştir. Kur'an'a göre İsmail peygamber de seçilmiş bir peygamberdir ve ona da vahiy gelmiştir (Harman 2001: 76-77).

İsmail peygamber, Türk edebiyatında doğumu, çocukluğu, gençliği ve peygamberliği gibi yönleriyle ele alınmıştır. Özellikle annesi Hacer ile birlikte Mekke'de bırakılması, burada zemzem suyunun fışkırması, babası İbrahim tarafından Allah'a kurban edilmek istenmesi, buna razı olup sabır ve teslimiyet göstermesi ve Kâbe'nin inşaatında babası ile birlikte çalışmasından bahsedilmiştir. Türk edebiyatında Hz. İbrahim'i konu edinen eserlerin çoğunda Hz. İsmail'den de bahsedilmiştir. Hz. İsmail hakkındaki müstakil eserlerin bir bölümünü halk için yazılan manzum ve mensur dinî hikâyeler oluşturmaktadır. Bu eserlerde daha çok İsmail'in kurban edilmek istenmesi olayı ve onun teslimiyeti anlatılmaktadır (Uzun 2001: 80-81).

Aksaraylı Îsâ'nın Destân-ı İsmâ’̂l adlı mesnevisi de Hz. İbrahim'in Hz. İsmail'i kurban etmek istemesi olayını anlatmaktadır. Aksaraylı Îsâ hakkında elimizde yazılı kaynaklara dayalı somut bilgiler yoktur. Konya, Aksaray çevresinde yaşaması; Mevlâna ve oğlu Sultan Veled'i bazı eserlerinde övmesi (06 Mil Yz A 3881/5); eserlerini Eski Anadolu Türkçesiyle yazması, XIV. yüzyıl veya buna yakın bir dönemde yaşamış olduğunu ortaya koymaktadır. Aksaraylı Îsâ'nın Destân-ı İsmâ’̂̂l mesnevisinin Hz. İsmail konusunda Türk edebiyatında yazılmış ilk edebî eser olması büyük olasılıktır. 


\section{Eser Üzerine İncelemeler}

\subsection{Eser ve Eserin Adl}

Eser, Arap harfli Türkçe ile yazılmış İslami dönem Türk edebiyatına ait kısa bir manzum halk hikâyesidir. Eser mesnevî nazım şekliyle ve aruz ölçüsünün Fẩilâtün Fâ'ilâtün Fâ'ilât kalıbıyla yazılmıştır. Eser halk için yazıldığı için son derece sade, akıcı bir Türkçe kullanılmıştır. Bu tür eserler genelde Beylikler ve Osmanlı Devleti'nin kuruluş devirlerinde yazılmıştır. Henüz tam anlamıyla ölçünlü (standart) bir dil oluşmamış ve eserler halkın kullandığı dil ile yazılmışlardır. Türk dil tarihinde bu devreye Eski Anadolu Türkçesi denir. Aynı dönemi ifade etmek için Eski Osmanlı Türkçesi, Tarihî Türkiye Türkçesi, Eski Türkiye Türkçesi vb. ifadeler de kullanılmaktadır. Eser, halk için yazılmış kısa bir dinî hikâyedir. Bu dönemde yazılan eserlerin büyük çoğunluğu ümmet çağı edebiyatına uygun olarak İslami bir çizgidedir. Amaç halka bazı basit dinî bilgi ve hadiseleri edebiyat yoluyla aktarmak ve onlarda bir coşku ve dinamizm oluşturmaktır. Bu hikâyeler genelde meddah şairler tarafından köy, kasaba ve şehirlerde halk meclislerinde okunmak için yazılmışlardır. Bu meddah şairlerin o dönem edebiyatı bir araç olarak kullanarak dinî bir görev icra ettiklerini düşünmek de hiç yanlış olmayacaktır. Fakat o dönem yazılan bu eserler Anadolu'da Türkçe ile yazılmış ilk ürünleri meydana getirmiştir. Eserin ne zaman yazıldığı metinde belirtilmemiştir. Fakat hikâyenin diğer bir nüshasında yazarı açıkça belirtilmiştir: Aksaraylı Îsâ (Millî Kütüphane: 06 Mil Yz A 3881/5). Aksaraylı Îsâ'nın eserlerindeki dil özellikleri onun XIV. yüzyılda veya buna yakın bir dönemde eserler veren bir yazar olduğunu göstermektedir.

Eserin adı Ankara Millî Kütüphane 06 Mil Yz A 6823/5 numaralı yazmada DestânI İsmâ'îl olarak belirtilmiştir. Eser mesnevi nazım şekliyle yazılmış dinî bir hikâyedir ve 128 beyitten oluşmaktadır. Eserin ikinci bir nüshası da Ankara Millî Kütüphane $06 \mathrm{Mil}$ Yz A 3881/5 numarada kayıtlıdır ve 90 beyitten oluşmaktadır. Hikâyenin adı ikinci nüshada da Dâstân-ı İsmâ̂îl olarak kaydedilmiştir. Ancak hemen belirtelim ki buradaki destan terimi eski edebiyatımızda genelde hikâye ya da öykülemeye dayalı eserleri belirtmek için kullanılırdı. Mensur hikâyelerde bile destan adı görmek mümkündür. Eski edebiyatımızda bu türden pek çok kelime hikâye ya da tahkiyeye dayalı eserleri anlatmak için kullanılırdı (Korkmaz 2012: 160-164).

Eserin nüshaları ile ilgili daha geniş bilgiler ilgili bölümde verilecektir. Eserin nüshalarından hareketle hikâyeyi günümüz Türkçesine İsmail'in Hikâyesi olarak çevirmek mümkündür. 


\subsection{Eserin Konusu ve İçeriği}

Destân-ı İsmẩ̂l, İslami dönem Türk edebiyatına ait mesnevi tarzında yazılmış kısa bir halk hikâyesidir. Eser 128 beyitten oluşmaktadır. Eserde dinî ve ahlaki bir konu ele alınmıştır. Eserde İbrahim peygamber ile oğlu İsmail peygamberin yaşadığı "Allah yolunda oğlunu kurban etme" olayı işlenmiştir. İbrahim peygamber, gece gündüz Allah'a dua edip kendisine bir oğul vermesini isterdi. Eğer bu dileği gerçekleşirse Allah için en sevdiği şeyi kurban edeceğini söylemişti. Allah, İbrahim peygamberin duasını kabul edip ona İsmail'i bağışladı. Zamanla İsmail büyüdükten sonra İbrahim peygamber düşünde Allah'ın ona: “Neden bizim için en sevdiğini kurban etmedin?” dediğini gördü. Hikâyede bu konu tahkiye edilmiş ve sonrasında gelişen olaylar anlatılmıştır.

İbrahim peygamber, İslam dini inançlarına göre "Hâlilullâh: Allah dostu" unvanını taşımaktadır. Hikâyede ondan bahsedilirken genelde Hâlil adı kullanılmıştır. Eserde özellikle 'Allah dostu' unvanı ile öne çıarılmış ve bu şekilde anılmıştır. Kur'an'da kendisinden en çok bahsedilen peygamberlerden biridir. İslami kaynaklarda şeceresinde Terah'ın oğlu olduğu ve soyunun Nuh peygambere kadar dayandığı belirtilmektedir (Harman 2000: 269).

İsmail peygamber, Hz. İbrahim'in oğludur. Kur'an'da adı geçen ve çeşitli vesilelerle anılan bir peygamberdir. Eserde anne ve babasına bağlı bir insan olarak vasfedilmiştir. Şeytan onu kandırmaya geldiğinde babasının Allah dostu olduğunu, yanlış iş yapmayacağını söylemişti. Eserde babasının onu Allah için kurban edeceğini öğrendiğinde tam bir teslimiyet gösteriyor ve Allah yolunda canını vermekten çekinmiyor. Kur'an'da on iki yerde adı geçmektedir. İbrahim peygamberin yaşlılık döneminde cariyesi Hacer ile evliliğinden doğmuştur ve ilk çocuğudur. Tevrat ve Hristiyan kaynaklarında İbrahim peygamberin kurban etmek istediği kişi İshak olarak açıklanır. İslami kaynaklarda da bu konuda ihtilaf olmakla birlikte Türk edebiyatında İbrahim'in Allah yolunda kurban etmek istediği kişi olarak İsmail peygamber ele alınır ve bu yönüyle işlenir. İsmail peygamber küçükken babası onu annesi ile birlikte Mekke'ye bugünkü Kâbe'nin bulunduğu bölgeye bırakmıştı. Daha sonra burada babası ile birlikte Kâbe'nin inşasında çalışmıştı. Ayrıca babası tarafından bu kutsal mekânı temiz tutmakla da görevlendirilmişti. Kendisi Allah tarafından peygamber olarak seçilmiş ve diğer peygamberler gibi kendisine de vahiy gelmiştir. İsmail peygamberin hayatı ile ilgili hadislerde çok az bilgi vardır; tarih, tefsir ve kısas-1 enbiya türü kitaplarda ise daha ayrıntılı bil- 
giler bulunmaktadır. Hz. Muhammed'in "Ben iki kurbanlığın oğluyum." hadisinde geçen iki kurbanlıktan biri İsmail peygamber diğeri ise babası Abdullah’tır (Harman 2001: 76-80).

Vasfi Mahir KocATÜRK, Büyük Türk Edebiyatı Tarihi adlı eserinde "Manzum Dinî Destanlar" bölümünde bu türden hikâyelere değinerek hususi kitaplığında bulunan bir yazma üzerinden İsmail Destanı hakkında şu bilgileri vermiştir:

"Bu eserde kaynağı Tevrat olan meşhur konu işlenmiştir:

İbrahim Peygamber Allah'a yalvararak kendisine bir oğul vermesini istemiş ve buna karşllık en sevgili şeyini ona kurban edeceğini vadetmiştir. Çok geçmeden oğlu İsmail dünyaya gelir. Onu pek severek vaadini unutur. Rüyasında Allah'ın hatırlatmasıyla yüz koç kurban ettiği hâlde vaadini yerine getirmemiş sayılır. Tanrı tarafından kulağına gelen bir ses sevdiğinin kurban edilmesini ve sözünden dönmemesini ister. En sevgili atlarını, develerini de kurban eder. Fakat vaadini yerine getirmemiş sayılır. Nihayet Tanrı kendisine İsmail'i boğazlaması gerektiğini bildirir.

İbrahim en derin babalık duygularına rağmen oğlunu Allah yolunda kurban etmeye karar verir. Kesmek üzere kıra götürür. Fakat boğazına sürdüğü bıçak kesmez. Bu sırada gökten bir koç iner, o kurban edilir, İsmail kurtulur.

Allah için her şeyin, en sevgili evladın bile feda edilmesi fikrini telkin eden hikâyeye hafif tasavvufi bir ruh eklenmiştir. Allah sevgisiyle birlikte gönle başka bir sevgi sığmaz, bütün başka sevgileri terk etmek gerektir.

İbrahim'in kurban etmeye karar verdiği oğluna karşı zaafları fakat bütün bunlara yine Allah sevgisinin galip gelişi, İsmail'in itaat ve masumiyetle boyun eğmesi, karardan haberi olmayan annesi Hacer'in oğluna sevgisiyle birlikte güveni ve Allah'a imanı sade, basit fakat patetik bir dille anlatılmıştır." (Kocatürk 2016: 121).

Eserde kıssada hisse olarak verilmek istenen mesaj Allah yolunda en sevdiğin şeylerden bile gerekirse vazgeçmek olarak belirtilebilir. İbrahim Peygamber, bu konuda Allah tarafından sınanmış ve bu sınavı başarıyla yerine getirmiştir. İsmail Peygamber de Allah emrine teslim olmuş, içindeki imanı ve Allah aşkını kanıtlamıştır.

\subsection{Hikâyenin Olay Özeti}

Cömertlik sultanı olan ve Allah tarafından kendisine Halil ismi verilen İbrahim peygamberin bir evladı yoktu. Geceleri uyuyamaz, ağlayarak Allah'a dualar eder ve kendisine bir evlat bahşetmesini gönülden dilerdi. Allah'a şöyle seslenirdi: “Allah'ım bana bir evlat ver, sana en sevdiğimi kurban edeyim". Bu dileği kabul oldu. Allah ona İsmail'i bağışladı. İbrahim peygamberin isteği yerine gelince Allah için beş yüz deve kurban etti. İsmail'i besleyip büyüttü. 
Bir gün İbrahim peygamber uykuya daldığında bir rüya gördü. Yüce Allah ona rüyasında "Niçin sevdiğini benim için kurban etmedin?" diye seslendi. İbrahim peygamberin bütün develerinden daha çok sevdiği yüz devesi vardı ve sabah olur olmaz hepsini Allah yoluna kurban etti. Fakat o gece rüyasında Allah ona yine seslenerek: "Ey Halil, sevdiğini bize kurban etmedin, verdiğin sözde durmadın" dedi. İbrahim peygamberin sevdiği yüz seçkin atı vardı, onların da hepsini sıra sıra kesti ve bütün sevdiklerimi Allah için bağışladım, verdiğim sözde durdum diye düşündü. Ancak o gece rüyasında Allah yine kendisine seslendi: "Ey Halil, verdiğin sözde durmadın, sevdiğini bize bağışlamadın. Senin sevdiğin İsmail'dir. Onu sana biz verdik, şimdi sen de onu bize geri ver. At, deve kesmeyi bırak ve İsmail'i bizim için kurban et." Halil uykudan uyandığında korkudan onu titreme tuttu. $O$ gece tam yetmiş kez bu rüyayı gördü. İsmail için çok ağladı ve bu işin yapılması gerektiğini, Allah'ın emrinin yerine getirilmesi gerektiğini anladı.

İbrahim peygamber, eğer bunu İsmail'in annesine söylerse içine ateş düşeceğini bildiği için gerçeği ona söylemeyip bir dostun düğününe gideceğini ve İsmail’i de yanında götüreceğini söyledi. Hacer'den İsmail'in başını yıkamasını, saçlarını taramasını ve temiz elbiseler giydirmesini istedi. Annesi Hacer; İsmail'in ellerini kınaladı, saçlarını taradı ve temiz elbiselerini giydirdi. İsmail'i babasıyla gönderirken ona sarıldı, gözlerinden öptü ve yüzünü yüzüne sürerek: "Sakın babandan ayrılma, benim bu dünyadaki ümidim sensin. Çabucak gidip gel, gözümü yollarda bırakma” dedi.

İbrahim, İsmail'i alıp gidince lanetlenmiş şeytan yaşlı bir ihtiyar kılığına girerek Hacer'in yanına gelir ve ona: “Sen ne yaptın? Kendi elinle oğlunu gurbete gönderdin. Gidip bir daha dönmeyecek. Onun tatlı sözlerini bir daha duymayacaksın ve güzel gözlerini bir daha görmeyeceksin. Babası onu kesmeye götürdü" dedi. Hacer: "Sen ne söylüyorsun, babası onu neden kessin?" der. Şeytan cevap verir: “Allah ona oğlunu kesmesini emretti. Onun bu sözü yerine getirmesi ve Allah'ın buyruğuna uyması gerek. Bu sebeple oğlunu kesecek." Bunu duyan Hacer: "O, Halil'dir. Allah dostudur. Kötü işi asla yapmaz. Allah buyruğu ne ise onu yerine getirir. Arada yol kesen ve kötü iş yapan sensin" der. Aradığını burada bulamayan şeytan bu sefer de İsmail'in yanına gider ve ona şöyle söyler: "Ey İsmail, baban seni kesmek için bıçağını biledi. Zavallı annen bunu duyunca gözyaşları içinde kaldı ve seni geri çağırmam için beni yolladı. Babanla gitme, geri dön." Bunu duyan İsmail: "Ey ihtiyar, bu senin söylediklerin nasıl sözlerdir? Allah, babamı Halil diyerek övmüştür. Hangi peygamber oğlunun kanını döker? Benim babam beni çok sever ve dünyayı benim gözümle görür. Yürü git buradan, beni oyalama." der. Şeytan, babasının onu keseceğini söyleyince İsmail öfkelenir ve bir taş alıp 
fırlatarak onun gözünü çıkarır. İsmail, babasının yanına giderek: "Baba, kocaman sakalı olan bir ihtiyar gördüm. Baban seni kesmeye götürecek, geri dön, dedi. Ben de öfkelenip taşı fırlattım ve onun sağ gözünü çıkardım. Bu davranışım doğru mudur, bilmiyorum." dedi. Babası İbrahim: "O, şeytandı. Onun fitnesi ve hilesi çoktur. Sen onu dinleyerek geri dönmedin ve doğru yoldan ayrılmadın, akıllı kişi asla şeytana uymaz." dedi.

İbrahim ve İsmail bu konuşmalardan sonra çöl yoluna düşüp tenha bir yere geldiler. İbrahim ağlayarak içinden şunları geçirdi: “Allah'ım, İsmail benim ciğerparemdir. Onu kesmeye nasıl dayanayım, onun güzel yüzünü nasıl kana boyayayım?”. Allah'ın emrini yerine getirmekten başka çaresi olmayan İbrahim bıçağını yetmiş kez oğluna sürdü fakat elleri titredi bir kılını bile kesemedi. Bunu gören İsmail: "Ey baba, merhamet gözdedir, sana bakarsam bana kıyamazsın ve beni kesmeye dayanamazsın. O yüzden gözlerimi bağla ve yüzümü yere doğru kapat. Bıçağını biledikten sonra ellerimi de bağla, yanlışlıkla sana dokunursam yarın kıyamet gününde cehennem ateşinde yanarım. Senden bir isteğim de şudur ki: Kanlı gömleğimi anneme gösterme.” dedi.

İsmail, vasiyetini bitirdikten sonra dizlerinin üstüne çöktü. Babası nergis gözlerini bağladı. Elleri ve ayakları da bağlanan İsmail, bunu görünce hâline çok üzüldü ve ağlayarak babasına şöyle dedi: "Ey baba, ben asi değilim, neden ellerim bağlı olsun. Ellerimi ve ayaklarımı çöz. Oğlun İsmail sana karşı gelmez." Bunun üzerine babası ellerini çözdü. İsmail boynunu uzattı ve babası bıçağı yetmiş kez onun boğazına sürdü fakat bıçak bir türlü kesmedi. Halil öfkelenerek bıçağı taşa vurdu ve taş baştan başa kesildi. Bunu görünce: "Ey asi bıçak, neden taşı kestin de bu işi tamamlamadın?” diye sordu. Bıçak dile gelip: "Ey Halil, Allah İsmail’in bir kılını bile kesmememi emretti. Herkes onun buyruğunu tutmak zorundadır, nasıl keseyim?" dedi.

Halil, bıçaktan bu cevabı işittiği sırada Yüce Allah Cebrail'e seslendi: “Çabucak İsmail'e kurbanı yetiştir ve kendini bizim için feda etmek isteyen bu canı kurtar." Bunu duyan Cebrail kurban etmek için bir koç getirdi. Allah İbrahim'e seslendi ve: "Ey Halil, düşün yerine geldi." dedi. İbrahim de: "Ben oğlumu kurban etmedim ve sözümde duramadım. Düşüm nasıl yerine gelebilir ki?" diye karşılık verdi. Allah tekrar seslenerek: "Ey İbrahim, bizim için oğluna bıçak sürdün. Senin dostluğun bizim katımızda gerçek oldu ve Allah'in emri yerine geldi. İsmail'in derdine derman bulundu. Sen de Allah'tan lütufta bulunarak bıçağı kendi nefsine çalma." dedi.

Hikâyenin en sonunda yazar, sözün burada bittiğini söyler ve Allah peygamberi Mustafa'nın ruhu için salavat getirilmesini ister. 


\subsection{Kahramanlar-Karakterler-Üçüncü Kişiler}

Hikâyedeki kişiler ve diğer varlıklar hikâyedeki önem sırasına göre belirtilecektir.

\section{1. İbrahim}

İbrahim peygamber, bu hikâyenin iki kahramanından biridir. Bir oğlu olması için gece gündüz Allah'a yalvarırdı. Eğer bir evladı olursa "En sevdiğimi kurban edeceğim." demişti. Çok geçmeden bir oğlu olur, oğlu zamanla büyür. İbrahim peygamber düşünde Allah'ın: Neden sözünde durmadın, neden en sevdiğini bize kurban etmedin" dediğini görür. Hikâye, İbrahim peygamberin Allah'a olan dostluğunun sınanması üzerine kuruludur. İbrahim peygamber Allah'a son derece bağlı ve sözlerine sadık bir insandır. Bu nedenle hikâyede ondan bahsedilirken genellikle Hâlilullâh veya Hâlil unvanı kullanılmıştır.

İbrahim peygambere düşünde en sevdiğini kurban etmesi bildirilince hiç tereddüt etmemiştir. Ne kadar koyunu, koçu, at1, devesi varsa hepsini Allah yolunda kurban etmiştir. Ancak düşünde her seferinde en sevdiğinin bunlar olmadığı söylenmiş ve bunları bırakarak oğlu İsmail'i kurban etmesi istenmiştir. İbrahim peygamber bu işin Allah'ın emri olduğunu anlayıp ne kadar üzülse de gereğini yerine getirmek istemiştir. Oğlunu en güzel kıyafetlerle giydirip çölde tenha bir yere götürüp durumu oğluna anlatmıştır. Oğlu Allah'ın emrine teslimiyet göstermiş fakat İbrahim peygamber bıçağı sürdüğünde bıçak onun bir kılını bile kesmemiştir. İbrahim peygamber Allah'ın emrini yerine getiremediği için çok öfkelenerek bıçağ 1 taşa vurmuştur. Daha sonra gökten Cebrail bir koç getirmiş ve onun kurban edilmesini istemiştir. Böylelikle İbrahim peygamber, Allah'a karşı olan dostluğuyla sınanmış ve bunu başarmıştır. Hikâyede oğlu İsmail ve eşi Hacer'e değinilmiş ailesinden olan başka kimseye değinilmemiştir.

\section{2. İsmail}

İsmail peygamber hikâyenin iki kahramanından biridir. Hikâyenin adı onunla anılmıştır. Fakat bazı nüshalarda Kıssa-i İsmail ve İbrahim denilir ki bu durum hikâyenin iki önemli kişisini göstermesi açısından önemlidir. İsmail peygamber, babası İbrahim peygamberin Allah'tan evlat dilemesi sonucu doğmuştur. Biraz büyüdükten sonra babasının düşünde en sevdiğinin İsmail olduğu ve onu kurban etmesi gerektiği söylenmiştir. Babası, annesinden onu yıkaması ve en temiz giysileri giydirmesini bir dostunun düğününe gideceğini söyler. Babası İsmail'le yolda giderken şeytan bir yaşlı kıllğında İsmail'i yoldan çıkarmaya çalışır ve babasının kendisini kesmeye götürdüğünü 
söyler. İsmail, babasının Allah dostu olduğunu ve kendisini çok sevdiğini söyler. Şeytan ısrar edince bir taş atarak onun sağ gözünü çıkarır. Günümüzde söylenen "Bir gözü kör şeytan" sözü bu dinî olaydan yadigâr kalmıştır. İsmail peygamber daha sonra bu durumu babasına anlatır, babası da o gördüğünün şeytan olduğunu onun işinin fitne ve fesat olduğunu söyler.

Babası, İsmail peygamberi tenha bir yere götürüp ona durumu anlatınca Allah'ın emrine teslimiyet gösterir. Önce ellerini ve ayaklarını bağlatır, sonra babasına ben asi değilim, oğlun İsmail sana karşı gelmez, der. Babası bıçağı sürdüğünde hiç kendini oynatmaz. Bu durum babasına olan güveninin ve onun doğru olan şeyi yaptığına inanmasından kaynaklanmaktadır. Hikâyede İsmail peygamberin babası ve annesine olan güveni tamdır. İyi ve sadık bir evlattır. Hikâyenin iki nüshası onun adıyla anılmışır. Bu hikâye aslında onun hikâyesidir.

\section{Hz. İsmail'in Annesi Hacer}

Hikâyede Hacer, İsmail'in annesidir. Babası onu götüreceği zaman oğlunu yıkayıp, tarayıp en güzel elbiselerini giydirir. Oğluna çabuk git gel, sen benim bu dünyadaki umudumsun; yollarına baktırma, der. Eşine karşı olan inancı ve güveni tamdır. oğlunu babasından ayrılmaması konusunda tembih eder. Babası ve oğlu yola koyulduktan sonra ilk olarak şeytan onun yanına gelir ve durumu anlatır. Hacer; o Allah'ın dostudur, yanlış iş yapmaz, arada yol kesen sensin, der. Şeytan ondan umduğunu bulamaz ve oradan uzaklaşır. Hikâyede Hacer'le ilgili bundan başka anlatım yoktur.

\section{4. İblis (Şeytan)}

Bu hikâyenin kötü kişisi İblis’tir. Hikâyede kişileştirilmiştir. İki yerde karşımıza çıkar. Önce Hacer'in yanına giderek İbrahim'in İsmail'i kesmeye götürdüğünü söyler. Hacer'in eşine karşı olan inancı sarsılmaz, ona haddini bildirerek oradan gönderir. Oradan istediğini bulamayan İblis bu defa yaşlı bir adam kıllı̆ına girerek İsmail'i kandırmaya çalışır. Fakat İsmail, babasına karşı olan sevgisinden taviz vermez. İblis'in ısrar etmesi sonucu bir taş alıp ona atar ve onun sağ gözünü kör eder. İblis, hikâyede insanlara karşı kötülük yapmak isteyen ve onların aralarını açmak isteyen bir karakterdir. Her türlü kötülüğün kaynağıdır. Hikâyeye göre kılık değiștirebilmesi olağanüstü özellikleri olduğunu göstermektedir. İblis, hikâyede insanlarla konuşan, kılık değiştirebilen bir karakterdir. 


\section{Bıçak}

Bıçak hikâyede kişileștirilmiş ve konuşturulmuştur. İbrahim peygamber bıçağı oğluna sürdüğünde İsmail'in bir kılını bile kesmez. İbrahim peygamber sinirlenip onu taşa attığında taşı baştan başa keser. İbrahim peygamber ona neden böyle yaptığını sorunca Allah emri böyledir, herkesin ona uyması gerek olduğunu söyler.

\section{Cebrail}

Cebrail, dinî hikâyelerde Allah'ın mesajlarını, emirlerini peygamberlere ve insanlara taşıyan büyük melektir. Bu hikâyenin sonunda Allah'in emri ile kurban edilmek üzere bir koç getirerek İbrahim peygambere Allah'ın İsmail'i bağışladığını, Allah'ın emrinin yerine geldiğini söyler.

Bundan başka hikâyede İslam dinine göre her şeyin yaratıcısı olan Allah konuşturulmuştur. Fakat Allah kavramını bir kişi ya da karakter olarak telakki etmemiz mümkün değildir. Her şeyin yaratıcısı, mutlak varlık olan, ebedî ve ezelî olan Allah'tır. Allah, hikâyeye göre 72 kez İbrahim peygamberin düşüne girmiş ve ona "En sevdiğini neden bizim için kurban etmedin?" demiştir. Son düşte yine bu en sevilen şeyin İsmail olduğunu, dostluk için onun kesilmesi gerektiğini söylemiştir. Hikâyedeki ana konu Allah'ın emrinin yerine getirilmesi üzerine kurgulanmıştır. Hikâyenin sonunda yüce Allah, kendini teslim eden İsmail'i bağışlamış ve onun yerine kesilmesi için Cebrail'le birlikte bir koç göndermiştir. Hikâyede dinî anlamdaki hisse Allah'a bağlı olmak ve onun emrine teslim olmaktır. Hikâyenin başlangıcı Allah'ın emrini tatbik etmek üzere başlamış, sonuç yine Allah'ın emri ile olmuştur.

\subsection{Eserdeki Mekân ve Zaman}

Eserde hikâyenin yer ve zamanı belirtilmemektedir. Bu durumda yazılı kaynaklardaki bilgileri taramak gerekmektedir. Tevrat'a göre Hz. İbrahim'in İshak'1 kurban etmeye götürdügü yer Moriya (Moriyya, Moriyâh, Moriah) diyarıdır. Moriah kelimesinin etimolojisi ve nereye delalet ettiği bilinmemektedir. Bir yoruma göre Moriah 'uzaktan görülebilen' yani 'yüksek yer' demektir. Yahudi geleneği Moriah diyarını, kurban yeri olan Moriah Dağı ve Kudüs'teki tapınak tepesi ile aynileştirmektedir. Ahd-i Atîk'te (Tevrat) geçen bir Moriya Dağı vardır. Bu dağ, Hz. Süleyman'ın mabedini yaptığı tepenin adıdır. Tarihçi Josephus'a göre bu tepe İshak'ın kurban edilmek istendiği Moriah diyarının dağıdır (Harman 2001: 80).

İslami kaynaklar, Hz. İbrahim'in İsmail'i 2 yaşındayken annesi Hacer ile birlikte henüz bir yerleşim yeri olmayan Mekke'ye getirdiğini belirtir. Hz. İbrahim, onları 
Mekke'ye bırakmış, onları koruması için Allah'a dua ederek oradan ayrılmıştır. Yaşadıkları yer bugünkü Kâbe'nin yakınlarıdır. İsmail'in kurban edilmek istenmesi olayı da buraya yakın bir tepe de gerçekleşmiştir (Harman 2001: 78). Fakat Yahudi kaynakları İsmail'in İshak doğduktan kısa bir süre sonra 14 yaşındayken evden ayrılıp annesi Hacer ile birlikte önce Beer-şeba, sonra Paran çölüne gittiklerini belirtmektedirler. Annesi İsmail'i burada Misır diyarından bir kadın ile evlendirir (Harman 2001: 76).

Hikâyenin zamanını tespit etmek ise çok daha güçtür. Kaynaklara göre İsmail peygamber doğduğunda Hz. İbrahim 86 yaşındaydı ve Kenan diyarında yaşamaktaydı. Kaynakların tahlil edilmesiyle ortaya çıkan yaygın görüşe göre MÖ 2200-2000 yılları arasında yaşamıştır (Harman 2000: 267). Bazı kaynaklar, Hz. İbrahim'in Babil kralı Hammurabi'nin çağdaşı olduğunu belirtirler (Hammurabi'nin doğum ve ölüm tarihleri MÖ 1810-1750 olarak belirtilmektedir). Hikâyede belirtilen İsmail'in kurban olarak kesilmek istenmesi olayı da bu dönem içinde ve Hz. İbrahim'in yaşlılık zamanında meydana gelmiştir.

\subsection{Eserin Nüshaları}

Eserin şu anki bilgilerimize göre bilinen iki yazma ve bir basma (taş baskı) nüshası vardır. Yazma nüshalar Ankara Millî Kütüphane Yazmalar Koleksiyonu'na kayıtlıdır. Basma nüsha ise Hikâye-i Mevlidü'n-Nebî (İstanbul, 1311) adlı eserin sonundaki manzum metinler içindedir.

\section{06 Mil Yz A 6823/5 Nüshası (Asıl Nüsha)}

Bu nüsha çalışmada kullandığımız esas nüshadır. Ankara Millî Kütüphane 06 Mil Yz A 6823/5 numarada kayıtlıdır. Eser 128 beyitten oluşmaktadır ve mesnevi nazım şekliyle yazılmıştır. Bu nüshada eserin yazarı açıkça belirtilmemiştir. Fakat aynı hikâyenin diğer bir nüshasında 89. beyitte yazar adı açıkça Aksaraylı Îsâ olarak kaydedilmiştir (bk. 06 Mil Yz A 3881/5). Bu nüsha eserin elimizdeki en iyi ve en ayrıntılı nüshasıdır. Diğer nüshadan 38 beyit daha fazladır. Son derece güzel ve okunaklı bir harekeli nesih yazısı ile yazılmıştır. Eserin adı yazmada Destân-ı İsmâ’̂l olarak geçmektedir.

Eser, yazmanın 17b-21b varakları arasında kayıtlıdır. Yazmada eserin telif veya istinsah tarihi ile ilgili hiçbir bilgi yoktur. Yazmanın iç ve dış ölçüleri 206x150 mm (160x93 mm) şeklindedir. Harekeli nesih yazısı ile her sayfa 14 satır yazı vardır. Kâğıt türü Abadî kâğıttır. Yazma şemseli, köşebendli, yıpranmış desenli, kâğıt kaplı mukavva bir cilt içindedir. Eser dinî ve ahlaki konulu manzum bir halk hikâyesidir. Yazmanın 
şirazesi dağınık, söz başları kırmızıdır. Yazma, 1992 yılında Abdülmecid Güldü'den satın alma yoluyla Millî Kütüphane Yazmalar Koleksiyonu'na girmiştir. Yazmada mesnevi nazım şekliyle yazılmış dokuz manzum halk hikâyesi vardır.

Yazmanın dil özellikleri onun XVII.-XVIII. yüzyıl veya daha sonraki bir dönemde istinsah edildiğini gösteriyor. Çünkü eser Eski Anadolu Türkçesi Dönemi'nde yazılmasına rağmen o dönemde sadece yuvarlak şekilli olan birçok ek yazmada hem düz, hem yuvarlak olarak iki şekilde de görülmektedir. Halk hikâyeleri ile ilgili yazmalar genelde halk arasında yaşamış ve muhafaza edilmiştir. Bu nedenle bu tür yazmalardaki en büyük dil özelliği birden fazla dönemin dilini yansıtmalarıdır. Eski Anadolu Türkçesi Dönemi'nde yazılan eserler sonraki dönemlerde istinsah edilirken istinsah edildiği dönemin dili ve dilin kullanım şekli de eserlere yansımıştır.

Yazmada bulunan hikâyeler sırasına göre şu şekildedir: 1. Dâstân-ı Serencâm 2. Dâstân-ı Şuhmâ (yazmada yanlış olarak Dâstân-ı Şehinşâh olarak verilmiştir.) 3. Dâstân-ı Geyik 4. Dâstân-ı Kesikbaş 5. Dâstân-ı İsmầîl 6. Dâstân-ı Cimcime Sultân 7. Dâstân-ı İbrâhim Edhem 8. Dâstân-ı Kız 9. Dâstân-ı Hibâl.

Eserin ilk ve son beyitleri şu şekildedir:

001 şöyle tefsīr içinde ḩalīle yalvarurdı dün ü gün dārü'l-celīle

090 bunlaruy 'sşḳna hatm olsun kelām vir șalavāt mușțafāya ve's-selām

Çalışma, eserin 06 Mil Yz A 6823/5 numaralı yazma nüshasına dayandığı için bu nüsha üzerine diğer başlıklar altında ayrıntılı incelemeler yapılacaktır.

\section{06 Mil Yz A 3881/5 Nüshası}

$\mathrm{Bu}$ nüsha eserin ikinci yazma nüshasıdır. Eserin $62 \mathrm{a}-65 \mathrm{~b}$ varakları arasındadır ve 90 beyittir. Her iki yazma nüsha aynı kaynaktan gelmektedir ve birbirine benzer nüshalardır. Ancak bu nüsha 90 beyittir ve diğer nüshaya göre beyit sayıları azalmıştır. Kalan beyitlerde çalıştığımız nüsha ile tam olarak paralel değildir. Her iki nüsha üzerinde yaptığımız incelemelerden çıan sonuç, bu iki nüshanın tenkitli metin için uygun olmadığı ve ayrı ayrı çalışılması yönündedir.

Eser adı bu yazmada Destân-ı Hazret-i İsmầ̂l şeklindedir. Bu nüshanın en önemli özelliği yazar adını içermesidir. Buna göre eserin yazarı Aksaraylı Îsâ'dır. Eserin dil özellikleri Aksaraylı Îsâ’nın XIV. yüzyıl veya buna yakın bir dönemde yaşadığını ortaya koymaktadır. Eser, Eski Anadolu Türkçesi dil özelliklerini taşımakla birlikte diğer 
nüsha gibi geç dönemde istinsah edildiğinden dolayı sonraki dönemlerin dil özellikleri de esere yansımıştır. Bu durum bu türden pek çok eserde görülen bir özelliktir.

Eser, yazmanın 62a-65b varakları arasında beşinci hikâye olarak kayıtlıdır. Her sayfada harekeli nesih yazısıyla yazılmış 13 satır bulunmaktadır. Eserin iç ve dış ölçüleri şu şekildedir: 225x158 mm (183x113 mm). Eserin kâğıt türü Suyolu filigranlı kâğıttır. Eser ciltsizdir, söz başları kırmızıdır ve yapraklarda yer yer rutubet lekeleri vardır. Yazmada telif veya istinsah tarihine ait herhangi bir kayit yoktur.

Bu yazmada bulunan hikâyeler sırasına göre şöyledir:

1. Dâstân-1 Kesikbaş

2. Dâstân-1 Güvercin

3. Dâstân-1 Geyik

4. Mevt-i Muhammed-nâme

5. Dâstân-1 Hazret-i İsmâ'îl

6. Dâstân-1 Hatûn 7. Dâstân-1 Ejderhâ

8. Dâstân-1 Cimcime Sultan

9. Dâstân-1 Muhammed (Yazmada yanlış olarak Dâstân-1 Muhammed Hanefî yazılmıştır.)

10. Dâstân-1 Hazret-i İbrâhim

11. Dâstân-1 Fatıma.

Eserin ilk ve son beyitleri şu şekildedir:

001 şöyle tefsīr içinde halīle

yalvarurdı dün ü gün dārü'l-celīle

090 bunlaruy '1şḳına ḩatm olsun kelām

vir șalavāt mușțafāya ve’s-selām

\section{Basma (Taşbaskı) Nüsha: Hikâye-i Mevlidü'n-Nebî, İstanbul: Matbaa-i Osma- niye 1311 [1895-96], 1323 [1907-08].}

Süleyman Çelebi'nin Mevlidü'n-Nebî (Vesiletü'n-Necât) adlı eserinin bazı basma nüshalarının sonunda halk meclislerinde okunan bazı dinî ve ahlaki hikâyeler de vardır. Bu hikâyelerden biri de Kıssa-i İsmâ'îl ve İbrâhîm Aleyhi's-selâm adlı hikâyedir. Bu hikâye yukarıda iki nüshasını verdiğimiz hikâye ile aynı konuyu anlatan hikâyedir. 
Yani, İbrahim peygamberin oğlu İsmail'i Allah'a verdiği söz doğrultusunda kesmeye çalışması ve hikâyenin sonunda Allah'ın emri ile Cebrail'in bir koç getirmesi olayı.

Eser, basma (taş bask1) nüshanın 34-38. sayfaları arasında ve toplam 81 beyitten oluşmaktadır. Yukarıdaki iki yazmanın 128 ve 90 beyitten oluştuğu düşünülürse bu nüshada anlatılanlar daha da kısaltılmış durumdadır. Eser harekeli bir nesih yazı ile her sayfada 21 satır olarak yazılmıştır. Eser Matbaa-yi Osmaniye'de 1311 [1895-96] ve 1323 [1907-08] yıllarında basılmıștır. Eser toplam 48 sayfadır.

Nüshada Mevlidü’n-Nebîden başka şu eserler vardır:

1. Vefât-1 Fâtıma

2. Hikâyet-i Geyik

3. Hikâyet-i Gügercin

4. Kıssa-i İsmâ'îl ve İbrâhîm Aleyhi's-selâm

5. Hikâyet-i Kesik Baş

6. Hikâyet (Dinî bir hikâye)

7. Hikâyet-i Deve ve sonda bir hatime duası.

Eserin ilk ve son beyitleri şu şekildedir:

01 evvel allāh adını yād idelim șoyra dönüp söze bünyād idelim

081 bunda ḩatm oldı bu kıșșa ey hümām mușțafānın rūḥ̂na bī-ḥad selām

Bu nüshalar dışında, Türk ve dünya kütüphanelerindeki yazmalar arasında Aksaraylı Îsâ'nın Destân-ı İsmail hikâyesinin değişik nüshaları ortaya çıkabilir. Fakat şunu da belirtmek gerekir ki gerek Hz. İbrahim gerekse Hz. İsmail ile ilgili eserler birbirinin içine geçmiş durumdadır. Bu konudaki yazmaların derlenmesi ve tasnif edilmesi bu çalışmayı aşan başlı başına ayrı bir çalışmanın konusudur.

\subsection{Eserin Kaynağı}

Aksaraylı Îsâ’nın Destân-ı İsmâ’̂̉l mesnevisi Arap-İslam kaynaklı bir eserdir. İslam dini ile ilgili bu türden pek çok eser Türk edebiyatında hikâyeleştirilmiştir. Kur'an'da Hz. İbrahim'in oğlunu kurban etmek istemesi olayı isim verilmeksizin Sâffât suresinde anlatılmıştır. Buna göre İbrahim, putperest kavmi tarafından atıldığı ateșten kurtulup 
onlardan ayrıldıktan sonra hiç çocuğu olmadığı için Allah'tan sâlih bir evlat ister ve kendisine akılll, iyi huylu bir erkek çocuk müjdelenir. Çocuk babası ile birlikte yürüyüp gezecek çağa gelince İbrahim'den oğlunu kurban etmesi istenir. Bunu oğluna bildirince oğlu emredileni yapmasını söyler, emre boyun eğip sabredenlerden olacağını söyler. İbrahim, oğlunu kurban etmeye teşebbüs eder fakat Allah tarafından tâbi tutulduğu bu sınavdan başarılı olur; oğlunun yerine kurban olarak gökten bir koç gönderilir, böylece oğlu da kurtulmuş olur (Harman 2001: 78).

Kurban edilecek çocuğun adının Kur'an'da bildirilmemesi, diğer taraftan Tevrat'ta, Yahudi ve Hristiyan geleneğinde bunun İshak olarak kabul edilmesi Müslümanlar arasında da görüş farklılıklarının ortaya çıkmasına sebep olmuştur. Bir kısmı İsmail'in, bir kısmı da İshak'ın kurban edilmek istendiğini ileri sürmüştür. Hz. Ömer, İbn Mes'ûd, Alkame b. Vakkâs, Kâ'b el-Ahbâr, İkrime el-Berberî, İbn Cerîr el-Taberî ve Suyûtî İshak'ın kurban edilmek istendiğini; Ebu't-Tufeyl, Saîd b. Müseyyeb ve daha başkaları da İsmail'in kurban edilmek istendiğini söylemişlerdir. Hz. Ali, İbn Abbas, Ebu Hureyre, Hasan-1 Basrî, İbn Ömer, Mücâhid b. Cebr, Saîd b. Cübeyr, Suddî ve Katâbe b. Diâme'den de her iki görüş yönünde rivayetler nakledilmiştir (Harman 2001: 78).

Tevrat'ta ise kurban edilmek istenenin İshak olduğu belirtilir. Olay aktarılırken Allah'ın İbrahim'i imtihan ettiği ve “Şimdi oğlunu, sevdiğin biricik oğlunu, İshak'ı al ve Moriya diyarına gir ve orada sana söyleyeceğim dağların biri üzerinde onu yakılan kurban olarak takdim et." dediği nakledilir (Tekvîn, 22/1-19), (Harman 2001: 79).

Türk edebiyatında İbrahim ve İsmail Peygamberler ile ilgili anlatılan kıssalarda kurban edilmek istenen kişi İsmail olarak geçmektedir. Türk edebiyatında işlenen konular Kur'an'a, hadislere ve bunlar dışındaki İslami literatüre uygundur. İslami kaynakların bazıları da kurban edilmek istenenin İshak olduğunu belirtse de Türk kültüründe bu konuda İsmail Peygamber ile ilgili rivayetler öne çıkmıştır.

Kur'an-1 Kerîm'de İbrahim Peygamber'in oğlunu Allah yolunda kurban etmek istemesi olayı isim verilmeksizin Sâffât suresinde 99-111. ayetlerde anlatılmıştır. Bu ayetlerin meali şu şekildedir:

(99) İbrahim bu felaketlerden kurtulduktan sonra "Ben durmayıp Rabbimin emrettiği yere gideceğim. O beni doğru yola götürür." dedi. (100) Sonra "Ya Rab! Bana hayırlı bir oğul bahşet." diye niyazda bulundu. (101) Biz de ona yavaş bir civan müjdeledik. (102) Vaktaki o civan babasıyla çalışabilecek bir yaşa bastı. İbrahim ona şöyle dedi: "Oğlum! Ben bir rüya gördüm: Seni boğazlıyorum. Bak sen buna ne diyeceksin?" oğlu dedi ki: "Baba! Emrolunduğunu yap, inşallah beni sabırlılar arasında göreceksin.” (103) Vaktaki her ikisi kazaya boyun eğdiler, babası oğlunu alnı yere gelmek üzere yatırdı. (104) Biz de ona nida ettik: İbrahim! (105) Rüyanın iktiza ettiği şeyi hakkıyla yaptın, biz iyi iş edenlere böyle mükâfat veririz. (106) Hakikaten en beliğ bir imtihan işte budur. 
(107) Ona oğluna bedel büyük bir koç verdik. (108) Sonra gelenler arasında İbrahim hakkında iyi bir nam bıraktık, (109) İbrahim'e selam olsun. (110) Biz iyi iş edenlere böyle mükâfat veririz. (111) Çünkü o, bizim mümin kullarımızdandır (İzmirli 1977: 450-451).

Türk edebiyatında yazarların bu olayı kendi hayal güçleri ile birleștirip kurgulamaları edebiyat sanatı açısından gayet doğaldır. Etkili, güzel ve sanatsal bir anlatım için bu gereklidir de. Eserde anlatılan olaylar İslami literatüre uygundur fakat incelenen nüshalar arasında bazı küçük ayrıntılar vardır. Bu da halk arasında yüzyıllarca okunup anlatılan bu eserler için normal bir durumdur. Bu tür ayrıntılar bazen artarak aynı eser için varyant noktasına kadar gelir. Bu tür hikâyeler belli bir noktadan sonra yazarın elinden çıar ve insanlar arasında yüzyıllarca halk hikâyeleri olarak okunup anlatilırlar.

\subsection{Eserin Yazarı Aksaraylı Îsâ}

Eserin yazarı çalıştığımız nüsha olan 06 Mil Yz A 6823/5 nüshasında geçmemektedir. Fakat bu eserin diğer bir nüshası olan 06 Mil Yz A 3881/5 nüshasının 89. beytinde açıç̧a belirtilmiştir:

089 işbu sözi süleymān bülbüli aḳsarāylı cisā yārün ḳulı

“Bu sözü söyleyen Süleyman'ın bülbülüdür, Aksaraylı Îsâ Allah'ın kuludur.”

Aksaraylı Îsâ'nın eserin dil özelliklerinden ve bu türlü hikâyelerin en yaygın olduğu dönemden hareketle XIV. yüzyılda veya buna yakın bir zamanda yaşadığı düşünülmektedir. Aksaraylı Îsâ'ya nispet edilen eserler şu şekildedir:

1. Hikâyet-i Şuhmâ

2. Miraçnâme: Miraçnâme nüshalarında Aksaraylı Îsâ'nın adı geçmemektedir. Metin Akar, tarafından başka bir eserden hareketle bu eserin Aksaraylı Îsâ'ya ait olduğu belirtilmiştir (Akar 1987: 155157).

3. Dâstân-1 İsmail

4. Kissa-i İbrahim

Aksaraylı Îsâ'nın eserleri ümmet çağı edebiyatına uygun olarak genellikle İslami bir çizgide, dinî ve ahlaki konular üzerinedir. Yazar İslam dini ile ilgili bu türden konuları işleyerek halk meclislerinde icra etmiş olmalıdır. Beylikler ve Osmanlı Devleti'nin kuruluş yıllarında bu tür hikâyeler anlatan çok sayıda meddahlar vardı. Aksaraylı Îsâ da bir meddah şair olmalıdır. Adında anlaşıldığı üzere Konya ve Aksaray çev- 
resinde yaşamıştır. Bazı eserlerinde Mevlâna ve Sultan Veled için övgülerde bulunduğuna bakılırsa o dönemin Mevlevî çevrelerine yakın bir şair olmalıdır (06 Mil Yz A 3881/5). Aksaraylı Îsâ'nın eserlerinden hareketle İslam dini ile ilgili konulara vâkıf olduğu ve ayrıca Arapça ve Farsça gibi dilleri bildiği anlaşılmaktadır. Eserlerinde yer yer Kur'an ve hadislere göndermeler vardır ancak bunlar büyük ölçüde değildir.

Aksaraylı Îsâ'nın eserlerindeki dil oldukça sade ve akıcı bir halk dilidir. Basit halk ruhuna uygun olarak dinî ve ahlaki hikâyeler oluşturup kasaba ve köylerde bunları halk meclislerinde okumuştur. İslam'ı halka sevdirip basit dinî kuralları halka anlatmak için bu tarz basit hikâyeler oluşturmuştur. Amaç halka dinî sevdirmenin yanında bu hikâyeler aracıllğı ile insanlara kıssadan hisse vermektir. Bu tür eserlerde genellikle bu dünyanın faniliği, asıl ve ebedî olanın öteki dünya olduğu ve bu nedenle ölmeden önce ölüme hazırlanma fikri yaygın olarak işlenmiştir (Korkmaz 2020: 107). Bu eserde ise Allah'a giden yolda en sevdiği şeyleri bile terk etmek fikri işlenmiştir. Hz. İbrahim, Allah için çok sevdiği oğlunu kurban etmek istemiş ve bu yolda sınanmıştır.

Aksaraylı Îsâ, XIV. yüzyılda veya buna yakın bir dönemde yaşamış önemli bir meddah şairdir. Günümüzde yayınlanan ve tespit edilebilen eserleri bir elin parmaklarını geçmemektedir. Bu tür manzum ve dinî halk hikâyeleri genellikler müstakil yazmalar hâlinde olmayıp bir yazmanın veya mecmuanın içerisinde bir parça durumundadırlar. Daha çok halk meclislerinde okunup anlatıldıkları için halkın elindeki yazmalarda da bu türden çok hikâye yer almaktadır. Önümüzdeki süreçte kaynaklar tarandıkça Aksaraylı Îsâ'ya ait daha başka eserlerin gün yüzüne çıkması muhtemeldir.

\subsection{Eser Üzerine Yapılan Çalışmalar}

1. Kocatürk (1970, 2016): Vasfi Mahir KoCATÜRK, Büyük Türk Edebiyatı Tarihi adlı eserinde "Manzum Dini Destanlar" bölümünde özel kütüphanesinde bulunan bir yazma üzerinden (06 Mil Yz A 3881) çeşitli halk hikâyeleri hakkında bilgi vermiştir. Bu destanlar arasında İsmail Destanı'ndan da bahsederek olayın küçük bir özerini vermiştir (s. 121-122). Bu bilgiler, eserin konusu ve içeriği kısmında belirtilmiştir.

2. Özalp 2014: N. Ahmet ÖzAlP, 2014 yılında yayımladı̆̆ı Hikâye-i Mevlidi'n-Nebi (Mevlid Hikâyeleri) adlı çalışmada Süleyman Çelebi'nin Vesiletü’n-Necât (Mevlid) adlı eserinin taş baskı nüshaları sonunda yer alan hikâyeleri yayınlamıştır. Bu hikâyeler içinde Hikâye-i İsmail ve İbrahim de vardır. Bu hikâyede yazar adı bulunmamaktadır. Eser, 81 beyitten oluşmaktadır ve bu metne göre 47 beyit daha azdır. Bu eser, Mevlid metinlerinin arkasında halk arasında Mevlid Hikâyeleri olarak anonim bir şekilde yaşamıştır. Yaptığımız tetkikler bu hikâyenin Aksaraylı Îsâ’ya ait olan hikâyeyle aynı 
hikâye olduğunu göstermiştir. Yazar çalışmada 81 beyitlik hikâyeyi Latin harflerine aktarmış ve günümüz Türkçesine çevirmiştir (s. 99-115). Eserden iki beyit şu şekildedir:

Şöyle gördüm kitab içre Halil

Tanrı’ya yalvarır “Ey Rabbi'l-celil

“Bir kitapta şöyle gördüm: Allah'ın dostu İbrahim Tann’ya yalvarır: “Ey ulu Rabb’im,”

"Bir oğul bağışla lütfunla bana

Sevdiğimi kurban eyleyem sana"

"Lütfunla bir oğul bağışla bana, bu bağışına karşıllk sevdiğimi kurban eyleyeyim sana."

Eser üzerine bilgi veren ve yapilan başlıca çalışmalar bunlardır. Bunun dışında Hz. İbrahim ve oğlu İsmail'i anlatan başka yazarlara ait çalışmalar da vardır. Bu çalışmalardan tespit edebildiklerimizi Kaynakça kısmına ekledik.

\section{ESERIIN DİLİ ÜZERİNE NOTLAR}

\subsection{Ses Bilgisi İncelemesi}

\section{1. Ünlü Değişmeleri}

/ i/ > /e/ Değişmesi: Bugün /e/ sesi ile yazılan bazı şekiller metinde /i/ şeklinde geçmektedir: gice (010), girü (025), vir- (110), yigrek (036), ir- (084).

Metindeki bir örnekte /e/ ünlüsü Eski Türkçede olduğu gibi devam etmektedir, bugün olduğu gibi /i/ şekline dönüşmemiştir: eyü (040).

Bazı kelimelerde Eski Türkçe döneminde /e/ olan ses metinde /i/ şeklinde geçmektedir: imdi (069), işit- (069), nice (057), nite (068).

Metinde hem /e/'li hem de /i/'li şekli bulunan bir örnek mevcuttur: di- (031) de-(024).

/u/ > /1/ Değişmesi: Bugün /1/ olarak telaffuz edilen bazı kelimeler metinde /u/'lu şekilde geçmektedir: ayruk (081), azdur- (090), baġlu (108), bakdur- (048), kanlu (105), șapșaru (033).

Bugün /u/ sesi ile kullandığımız bazı örnekler metinde < $<>$ ile yazılmıştır: bunı (086), buyurıcı (066), dostliginda (124), korkıdan (033), kurtıl- (083), urucl (066).

Bazı kelimelerin hem $<\mathrm{u}>$ ile hem de $<1>$ ile yazılmış şekilleri çalışmada mevcuttur: oku- (073) oḳ- (040), yavuz (064) yaviz (090). 
/ü/ > /i/ Değişmesi: Bugün /i/'li olan bazı kelimeler metinde /ü/'lüdür: bildür(074), bellü (061), degül (108), getür- (100), giydür- (045), kendü (053), niçün (060).

Günümüzde /ü/'lü olan bazı şekiller metinde /i/'lidir: büyi- (014), ötri (071), yüri(081).

Metinde hem /ü/'lü hem de /i/'li şekilde geçen bazı örnekler de bulunmaktadır: dügüne (036) dügine (040), sevgüli (016) sevgili (122).

\section{2. Ünlü Uyumu}

Kalınlık - İncelik Uyumu: Bu uyum oldukça kuvvetlidir.

Kalınlık-incelik uyumuna uyan bazı örnekler şu şekilde geçmektedir: buyrugina (115), giydürür (039), kulaġı (056), öldürmege (074), saġışladı (010), belinledi (034).

Uyum dışı kalan \{-iken\} zarf fiil eki yalnızca bir örnekte görülmektedir: çalarken (104).

Düzlük - Yuvarlaklık Uyumu: Düzlük-yuvarlaklık uyumu büyük ölçüde sağlanmıştır. Düzlük-yuvarlaklık uyumuna giren yaklaşık 490 civarı kelime bulunurken, bu uyuma uymayan yaklaşık 180 civarında kelime bulunmaktadır.

Düzlük-yuvarlaklık uyumuna girmiş bazı örnekler şunlardır: aǵladı (034), almayasin (126), bağışlamadıy (023), dilegim (105), gölmegim (105), işlemedin (113), og̉luya (124), öldürmege (074), sevgili (122), țonların (045), uykudan (029), yavız (090).

Düzlük-yuvarlaklık uyumuna girmeyen bazı örnekler şunlardır: atasıdur (064), ayruk (081), bag̀lu (108), besledüg (057), kendüye (107), korkııan (033), sapsaru (033), urucı (066).

\section{3. Ünlü Düşmesi}

Ekleşme sırasında meydana gelen ünlü düşmesine örnekler mevcuttur ve bu örnekler şu şekildedir: oǵlinı < og̉ul+1+nı (041), beyzi < beniz+i (033), emrine < emir $+\mathrm{i}+n+e$ (125).

\section{Birleşme}

Türkçede ünlü ile biten bir kelimeye yine ünlü ile başlayan bir ek veya kelime eklendiğinde iki ünlü yan yana gelemeyeceği için ünlü harflerden biri düşer ve bir birleşme meydana gelir. Metinde bulunan birleşme örnekleri şunlardır: böyle $(063)<$ bu + eyle, kendüzinüy (052) < kendü + öz, nesne (123) < ne + ise + ne, niçün (077) < ne + içün, n'eyledi $(021)<$ ne + eyle-, n'ideyim (095) < ne + it-, şöyle (016) < şu + eyle. 


\section{5. Ünsüz Değişmeleri}

/b/ > /p/ Değişimi: Bir kelime çoğu yerde Eski Türkçede olduğu gibi /b/'li şekilde geçmektedir fakat üç örnekte /p/'ye dönmüşşekli de mevcuttur: bıçaḳ (110) $\rightarrow$ plçak (124).

/b/ > /v/ Değişimi: Eski Türkçede bulunan bazı kelimelerin ön ses, iç ses ve son ses durumundaki /b/'leri /v/'ye dönüşmüştür. Metinde /v/'ye dönüşmüş şekillere örnekler bulunmaktadır: bar- > varmaǵll (075), bir- > virdim (025), yabız > yavız (090) / yavuz (064).

/t/ > /d/ Değişimi: Bu değişim karışık bir şekilde kendini göstermektedir. Metindeki /d/'li örnekler şunlardır: dahı (079), ditremek (029), dutdı (029). /t/'yi muhafaza eden örnekler kalın sıradan kelimeler olup <tı harfi ile yazılmışlardır: țokına (104), țolup (051), țonlarl (039), țurmag்ll (028), țuydı (072).

/k/ > /g/ Değişimi: Eski Türkçede /k/ ile gösterilen bazı şekillerin Batı Türkçesinde /g/ ile yazıldığı görülmektedir. Metinde geçen örneklerden bazıları şunlardır: geldi (038), gerek (032), getürdi (119), gidem (036), gölmegim (105), göyülden (009), gün (011). /k/ sesini devam ettirip /g/'ye dönüşmeyen örneklerden bazıları şöyledir: kendü (053), kendüzị (053), kişi (091).

/ḳ/ > /h / Değişimi: Türkçe kelimelerde ön ses durumunda /h/ sesi olmadığından ön ses durumundaki /ḳ/'lar kendini korumaktadır (Özkan 2000: 107): kaçan (091), kanǵr (078), kanı (057). İç ve son ses durumundaki /k / > /h/ değişikliğinin Metinde iki örneği bulunmaktadır: dahı (055), uyhudan (033).

\section{6. Ünsüz Benzeşmesi}

İki ünlü arasında bulunan sedasız ünlülerin sedalılaşmasına verilecek örneklerden bazıları şunlardır: gidelüm < git-elüm (002), ideyim < it-eyim (037), kulaġı < kulaḳ+1y (056), ayag்ım < ayak+1m (109).

\section{Göçüşme}

Özellikle Anadolu ağızlarında görülen bu ses olayının sadece bir tane örneği bulunmaktadır: gölmegim < gömlek+im (105).

\section{Hece Düşmesi}

tur- fiilinden gelen, üçüncü teklik şahıs bildirme eki olan durur'un metinde üç örneği bulunmaktadır: muțī‘ durur (109), kul durur (115), ol durur (115). \{-dUr\} şeklinin 
daha fazla sayıda örneği bulunmaktadır: kanıdur (073), atasıdur (064), buyrugiıdur (032), cigerümdür (095), halilldür (064), nedür (079).

\section{2. Şekil Bilgisi İncelemesi}

\section{1. Çokluk Eki}

Çokluk eki, \{+lAr\} olarak geçmektedir: șaçlarını (044), țonları (039), elleri (098), gözlerim (048).

\section{2. İyelik Ekleri}

1. Teklik Şahıs İyelik Eki: Bu ek, $\{+(\mathrm{X}) \mathrm{m}\}$ şeklinde geçmektedir: atam (077), anama (105); ayaġım (109), cānım (047), kanım (079); gölmegim (105), dilegim (105), ümiżim (047), cigerimdür (095); șuçum (079); elümi (103), yüzümi (100), ismāciliüm (034).

2. Teklik Şahıs İyelik Eki: Bu ek, $\{+(\mathrm{X}) \mathrm{y}\}$ şekillerinde geçmektedir: anay (072), ataydan (047); kulag்ı (056), kanııı (071), og̉lıı (026); kavline (019), nefsige (126), sözine (019); oǵluy (109), oǵlunı (030); düşüg (120).

3. Teklik Şahıs İyelik Eki: Bu ek, \{+(s)I\} şekillerinde geçmektedir: atı (021), dostı (066), kulı (067), buyrugidur (032); beyzi (033), hāaceti (012), mekri (088); anası (041), atastdur (064); fitnesi (088).

1. Çokluk Şahıs İyelik Eki: Bu ek, $\{+(\mathrm{X}) \mathrm{mXz}\}$ şeklinde iki örnekte geçmektedir: 'aşkııııza (026), hażretümüze (124).

2. Çokluk Şahıs İyelik Eki: Bu ekin, örneği yoktur.

3. Çokluk Şahıs İyelik Eki: Bu ek, \{+lArI\} şeklinde geçmektedir: țonları (039), șaçlarını (044), elleri (098), gözlerin (055).

\section{3. İsim Çekimi}

Yalın (Nominatif) Hâl: Bir ismin herhangi bir hâl eki almadan kullanılmasıdır. Metinde çok sayıda örneği bulunmaktadır: deve (028), baba (084), cān (001), gün (011), tanrl (092).

İlgi (Genitif) Hâli Eki: Bu ek, $\{+\mathrm{Xy}\}$ ve $\{+\mathrm{nXy}\}$ şekillerinde geçmektedir: halikin

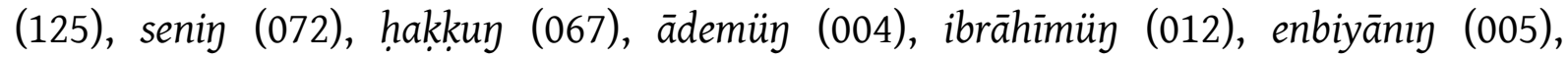

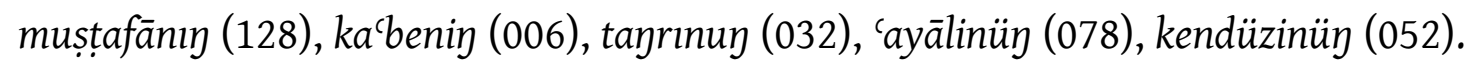

Yönelme (Datif) Hâli Eki: Metinde \{+A\} şeklinde geçmektedir: ḳana (028), oda (104), țaşa (112), yola (048), ādeme (003), cebrā̄ìle (117), düğüne (036), göyüle (123), ḥācere (038). 
Yükleme (Akkuzatif) Hâli Eki: $\{+I\}$ akuzatif eki daima düz ünlülü şekilde görülmektedir: bıçag̀ı (098), cihānı (050), cānı (118), hāceti (012), ismā̄ili (010), sözi (024). Üçüncü şahıs iyelik eklerinden sonra gelen $\{+n\}$ akuzatif ekinin örnekleri de metinde görülmektedir: kulaġın (001), ḳlın (114), șaçın (038), dizin (106), gözin (046), sözin (056). Üçüncü şahıs iyelik eklerinden sonra gelen $\{+n\}$ akuzatif ekinin metinde $\{+n\}$ şeklinde yazımı da görülmektedir. Bu bir imla hatasıdır. Bu tarz halk metinlerinde böyle imla

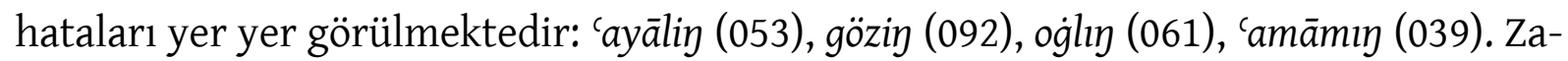
mirlerden sonra gelen $\{+n I\}$ akuzatif eki arkaik olarak bir iki örnekte görülmektedir: ani (027), buni (074).

Bulunma (Lokatif) Hâli Eki: Bu ek, $\{+\mathrm{dA}\}$ şeklinde geçmektedir: cihānda (004), dünyāda (047), kitābda (006), düşde (015), halvetde (037), yerdedür (099).

Uzaklaşma (Ablatif) Hâli Eki: Bu ek, \{+dAn\} şeklinde geçmektedir: kororkıdan (029), şeyțāndan (083), uyhudan (033), göyülden (009), ismā̄îlden (122), deveden (016).

Yön (Direktif) Ekleri: \{+rü\} yön eki kalıplaşmış olarak sadece bir kelimede görülmektedir: girü (025).

Vasıta (Enstrumental) Hâli Eki: Metinde $\{+1 \mathrm{~A}\},\{+1 \mathrm{~A}\}$ ve $\{+(\mathrm{X}) \mathrm{n}\}$ vasıta ekleri geçmektedir: atasiylla (045), gözüm-ile (080), senüyle (048), zahmetle (057). Metindeki bir kelimede $\{+(\mathrm{X}) n\}$ vasıta eki kalıplaşmış olarak görülmektedir: içün (027).

\section{Zamirler}

\section{1. Şahıs Zamirleri ve Çekimleri}

1. Teklik Şahıs Zamiri (Ben): ben (025), beni (040), benim (077), baja (008).

2. Teklik Şahıs Zamiri (Sen): sen (020), senden (071), seni (072), seniך (076), sen misin (047), sensin (066), senüyle (048), saya (104).

3. Teklik Şahıs Zamiri (0l): ol (090), aya (003), anı (027), anı̣ (060).

1. Çokluk Şahıs Zamiri (Biz): bize (118), bizi (123), bizim (027).

2. Çokluk Şahıs Zamiri (Siz): Metinde örneği yoktur.

3. Çokluk Şahıs Zamiri (Anlar): Metinde örneği yoktur.

4.2. İşaret Zamirleri: bu (053), buna (079), bunda (127), bunı (074), anca (011), anda (057), andan (002).

4.3. Dönüşlülük Zamirleri: kendü (053), kendüye (107), kendüzinün (052), kendüzin (053). 
4.4. Belirsizlik Zamirleri: kamusin (021), kang்ı (078), cümle (016), ayruk (081), biri (005).

4.5. Soru Zamirleri: ne (032), nedür (079).

\section{Fiil Çekimi}

\subsection{Bildirme Kipleri}

Geniş Zaman: Metinde geniş zaman eki olarak $\{-(\mathrm{A}) \mathrm{r}\},\{-(\mathrm{I}) \mathrm{r}\}$ ve $\{-(\mathrm{U}) \mathrm{r}\}$ ekleri görülmektedir: öger (077), n’ider (017), sever (080), örerin (006), gönderir (045), boġazlar (058), ünder (073), diler (009), kılur (064), țurur (017), geydürür (045), öldürür (080). Geniş zamanın olumsuzu \{-mAz\} ekiyle yapılmaktadır. Örneklerden bazıları şunlardır: țurmaz misin (020), bilmezem (087), eylemezsin (015), kesmez (098).

Görülen Geçmiş Zaman: Görülen geçmiş zaman eki $\{-d X\}$ olarak geçmektedir. Ünsüz benzeşmesine girmemiştir. boġazladı (021), kaḳıdım (087), țaşladın (053), ḳıldılar (003), baġışlamadıy (023), uyumadı (010), belinledi (034), gördim (084), kesdip (113), irdiler (094), kesmedim (121), gitmedip (089), okudum (006), urdum (087), țurmaduy (019), geldüm (086), didüm (075), besledüy (057), işledüy (053), virmedüy (019).

Öğrenilen Geçmiş Zaman: Öğrenilen geçmiş zaman eki \{-mIş\}'’n tek bir örneği vardır, bu örnek de öğrenilen geçmiş zamanın hikâyesi üçüncü teklik şahıs şeklinde geçmektedir: olmışdı (033).

Gelecek Zaman: Eski Anadolu Türkçesinde umumi gelecek zaman eki olan (Özkan 2000: 137) \{-IsAr\} metinde dört yerde geçmektedir: dökiser (071), gelmeyiser (055), görmeyiser (056). \{-AsI\} şekli de bir örnekte geçmektedir: oġlını boġazlamag் iltesi (041).

\subsection{Dilek Kipleri}

İstek Kipi: İstek eki $\{-A\}$ 'dir. Eski Türkçedeki $\{-g A\}$ ve $\{-g A y\}$ 'dan gelmiştir. Eski Türkçedeki gelecek zaman ekinin /g/'si Batı Türkçesine geçerken düşmüş, böylece \{A\} istek eki ortaya çıkmıştır. (Ergin, 1993: 294). Bu ekin metindeki örneklerinden bazıları şöyledir: yanam (104), alam (037), gidem (037), iletem (040), kurtılasın (083), çalmayasin (126), döymeyesin (102), uya (091), țokına (104), șiǵmaya (123), n’ide (062), gide (094), işitmeye (056).

Emir Kipi: Emir kipinde ek şahıslara göre değişmektedir:

1. Teklik Şahıs Emir Eki: Birinci teklik şahıs emir eki olarak \{-(A)yIm\} şekilleri geçmektedir: aldayım (037), kana boyayım (096), yol gözleyim (036), n’ideyim (095), kurbān ideyim (037), döyeyim (096). 
2. Teklik Şahıs Emir Eki: İkinci teklik şahıs bazen eksiz bazen de \{-gll\} eki kullanılarak gösterilmiştir: diple (001), kurtar (118), uyan (024), boġazlaǵl (109), yugill (028), bilgil (063), döngil (075), irgürgil (118), eylegil (027), söylemegil (081).

3. Teklik Şahıs Emir Eki: Az sayıda örneği vardır ve $\{-s X n\}$ şekillerinde geçmektedir: klymasin (102), söylesin (067), olmasun (104), eylesün (067), kessün (111).

1. Çokluk Şahıs Emir Eki: Birinci çokluk şahıs \{-AlUm\} olarak geçmektedir ve iki örneği vardır: gidelüm (002), virelüm (002).

2. Çokluk Şahıs Emir Eki: İkinci çokluk şahıs \{-In\} olarak geçmektedir ve iki örneği vardır: bakmayın (101), yakmayın (101).

3. Çokluk Şahıs Emir Eki: Üçüncü çokluk şahıs emir ekinin örneği yoktur.

Şart Kipi: Sadece bir örnekte $\{-\mathrm{sA}\}$ şart eki geçmektedir: ol ne dise ol sā'at itmek gerek (032).

Gereklilik Kipi: Gereklilik kipi istek kipi + gerek şeklinde iki örnekte geçmektedir: tayrınuy buyruġını gerek țuta (094), ismācīli ol gerek ḳurbān ide (062).

\section{Cevher Fiili ve Bildirme Ekleri}

$i$ - fiili Eski Türkçede er- şeklindeydi. Normal bir yardımcı fiil olan ve bütün kipleri bulunan er- fiilinin Batı Türkçesine geçerken /r/'si düşmüş /e/ > /i/ değişmesi ile ünlüsü de değişerek $i$ - şekli ortaya çıkmıştır (Ergin, 1993: 299). $i$ - fiilinin dört kipi vardır: Geniş zaman, görülen geçmiş zaman, öğrenilen geçmiş zaman, şart kipi. Metinde cevher fiilinin geniş zaman, görülen geçmiş zaman bir de şart kipinin örnekleri bulunmaktadır. Görülen geçmiş zaman örnekleri şunlardır: iblīs idi (088), telbis idi (088), ağlar idi (007), diler idi (091). Şart kipinin örnekleri şu şekildedir: eger dir isem anasına (035), tanrı buyurdı ise (065). Cevher fiilinin geniş zaman eklerine bildirme ekleri denir. Bildirme eklerinden 1. ve 2. şahıs için kullanılanlar şahıs zamirlerinden, 3. şahıs için kullanılanlar tur- fiilinden gelişmiştir (Özkan 2000: 144). Metinde sadece 1. teklik şahıs bildirme eki, 2. teklik şahıs bildirme eki ve 3. teklik şahıs bildirme eki görülmektedir:

1. Teklik Şahıs Bildirme Eki: Bir örnekte bildirme ekinin olumsuzunda birinci teklik şahıs eki olan \{-Um\} görülmektedir: ‘āṣī degülüm (108).

2. Teklik Şahıs Bildirme Eki: Bir örnekte \{-sIn\} eki görülmektedir: sensin arada iblīs yol urucı (066).

3. Teklik Şahıs Bildirme Eki: $\{$-dUrUr\} ve $\{$-dXr\} şekillerinin örnekleri bulunmaktadır: saya muțī durur oğluy ismācil (109), buyruk anıydur buyuran ol durur (115), 
hakdır āhir bu sözi saya deyen (024), ol ḩalildir yavuz işi nite ḳılur (068), didi bu ne işdir kim işledüy (053), baya ünder ismācīlüm kanıdur (073), bu ne ma`nīdür șuçum nedür benim (079).

7. Fiillerde Soru Şekli: Soru eki \{-mI\}'dir. Metindeki örnekleri şunlardır: yā ḩalīl sen ḳavline țurmaz mısın (020), sevdügün nesneyi terk itmez misin (020), dünyāda vāz ümizim sen misin benim (047).

8. İsim-Fiiller: En işlek mastar eki \{-mAk\} ekidir (Gülsevin 2007: 122) metinde görülmektedir. Bu örneklerden bazıları şunlardır: tạrınuy buyruġıdur țutmak gerek (032), ya boǵazlamaǵa nice döyeyim (096), başını țaramaǵa ḳıldı yaraḳ (043), at deve boġazlamaǵı sen ḳoğıl (028), ne çāre itmek gerek (097), ditremek dutdı anı ol ḳorḳıdan (029), didi işlemek gerek işbu işi (031), iletür atạ uş seni öldürmege (086), vardı girü gelmege (054).

9. Sıfat-Fiiller (Partisipler): Fiillerin, zamana bağlı isim ve sıfat şekilleridirler. İsimler gibi çokluk, iyelik ve hâl eklerini alırlar (Gülsevin 2007: 123). Metinde geçen sıfat-fiil ekleri şunlardır:

\{-dUk\}: Bu ekin sadece ince sıradan şekli geçmektedir: söyledügi sözler senin nice (076), sevdügümi kurbān eyleyem saya (008), seni boġazlamaġa iletdügin atay (072).

\{-An\}: kurtar ol bize fidā olan cānı (118), buyruk anıydur buyuran ol durur (115), gör ne ḳılur bu cihānı yaradan (050), bizi seven göyüle nesne șiġmaya (123).

10. Zarf-Fiiller (Gerindiumlar): Şahıs ve zaman belirtmeyen, yalnızca hareket kavramı ifade eden fiil şekilleridir (Özkan 2000: 151). Fiilleri başka fiillerle bağlamak üzere zarflaştıran eklerdir (Gülsevin 2007: 125). Metinde geçen zarf-fiil ekleri şunlardir:

\{-A\}: Bu ekin metinde sadece bir örneği bulunmaktadır: gide gide irdiler bir halvete (094).

\{-U\}: țur örü nice yatursın uyan (024), ḳurbān eyle ismācīli țur örü (025).

Kalıplaşmış edat olarak kullanılmıştır: dahı (055) < tak-1, girü (025) < gir-ü (= sonra), ötri

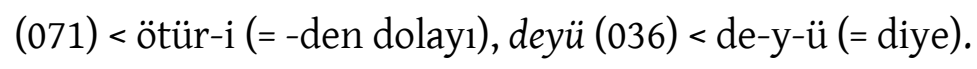

\{-ken\}: $i$ - fiilinin zarf-fiil şeklidir. Metinde bir örneği bulunmaktadır: olmasun bıçak çalarken el șalam (104).

\{-Up\}, \{-UbAn\}: ey nice kişileri ol azdurup (090), fitnelige ol yavuz mel'ūn țolup (051), dile gelüp didi bıçak yā halīl (114), ḳorḳuban girü dönüp sen gitmedin (089); söze andan başlayuban gidelüm (002), korkuban girü dönüp sen gitmediy (089), görüşüben öpdi hem iki gözin (046), iledüben halvetde kurbān ideyim (037), döküben yere anıy aldı cānın (078). 


\section{Transkripsiyonlu Metin ve Çeviri}

\begin{tabular}{|c|c|c|}
\hline [17b] & hazāa destān-1 ismā'īl aḥvāli ${ }^{1}$ & $\begin{array}{c}\text { İsmail'in Hikâyesi } \\
\text { (İsmail'in Başından Geçenlerin Hikâyesi) }\end{array}$ \\
\hline 001 & $\begin{array}{l}\text { cān ḳulaġin aç dinle bir zamān } \\
\text { bir cacāyib bir gaarāyib dāsitān }\end{array}$ & $\begin{array}{l}\text { Can kulağını aç ve bir zaman (beni) dinle. Acayip } \\
\text { ve hayret verici bir hikâye (anlatacağım). }\end{array}$ \\
\hline 002 & $\begin{array}{l}\text { c1şk-1la bir ḩoş șalavāt virelüm } \\
\text { söze andan başlayuban gidelüm }\end{array}$ & $\begin{array}{l}\text { Aşkile güzel bir salavat verelim, söze ondan sonra } \\
\text { başlayalım. }\end{array}$ \\
\hline 003 & $\begin{array}{l}\text { hak tecalā ādeme ḳıldı vücūd } \\
\text { ḳıldılar aya melā'ikler sücūd }\end{array}$ & $\begin{array}{l}\text { Yüce Allah Adem'e vücut verdi, melekler ona } \\
\text { secde ettiler. }\end{array}$ \\
\hline 004 & $\begin{array}{l}\text { ādemün geldi belinden evliyā } \\
\text { bī-ḥisāb oldı cihānda evliyāa }\end{array}$ & $\begin{array}{l}\text { Adem'in neslinden veliler geldi, dünyada sayısız } \\
\text { veli oldu. }\end{array}$ \\
\hline 005 & $\begin{array}{l}\text { enbiyānıı biri sulțān-1 kerem } \\
\text { ol [halīl]ullāh-1 şāh } 1 \text { muḥterem }\end{array}$ & $\begin{array}{l}\text { Peygamberlerden biri cömertlik sultanı, saygıde- } \\
\text { ğer hükümdar Halilullâh'tır. }\end{array}$ \\
\hline 006 & $\begin{array}{l}\text { şöyle oḳudum kitābda her gice } \\
\text { ka`benin bünyādın örerin ey ḩoca }\end{array}$ & $\begin{array}{l}\text { Bir kitapta her gece şöyle okurdum: Ey Hoca, } \\
\text { Kâbe'nin binasını yaparım. }\end{array}$ \\
\hline 007 & $\begin{array}{l}\text { uyhuya varmaz idi ağlar idi } \\
\text { dileyüp ḥaḳdan gönül bağlar-ıdı }\end{array}$ & $\begin{array}{l}\text { (İbrahim peygamber), uyuyamaz ve ağlardı. Al- } \\
\text { lah'tan dileyip (ona) gönül bağlardı. }\end{array}$ \\
\hline 008 & $\begin{array}{l}\text { eydür ey hak bir 'ayāl virgil baya } \\
\text { sevdügümi ḳurbān eyleyem saya }\end{array}$ & $\begin{array}{l}\text { Şöyle derdi: Ey Allah'ım, bana bir evlat ver, sana } \\
\text { sevdiğimi kurban edeyim. }\end{array}$ \\
\hline 009 & $\begin{array}{l}\text { n'eyleyüp ol ḩoş gönülden dirdi } \\
\text { tayrıdan ol bir cayāl diler idi }\end{array}$ & $\begin{array}{l}\text { O, ne söylerse gönülden söylerdi. Tanri'dan bir } \\
\text { evlat isterdi. }\end{array}$ \\
\hline 010 & $\begin{array}{l}\text { ḳırḳ gice uyumadı șaǵışladı } \\
\text { ḥak ạa ismācīli bağışladı }\end{array}$ & $\begin{array}{l}\text { Kırk gece uyumayıp düşündü. Allah, ona İsmail’i } \\
\text { bağışladı. }\end{array}$ \\
\hline 011 & $\begin{array}{l}\text { anca yalvardı dün ü gün hażrete } \\
\text { tā halīl ismācīle oldı ata }\end{array}$ & $\begin{array}{l}\text { Gece gündüz o kadar Allah'a yalvardı ki; sonunda } \\
\text { Halil, İsmail'e baba oldu. }\end{array}$ \\
\hline 012 & $\begin{array}{l}\text { hāāceti ibrāhīmün oldı revā } \\
\text { ḳurbān itdi ḥaḳk-ıçun beş yüz deve }\end{array}$ & $\begin{array}{l}\text { İbrahim'in isteği yerine geldi ve Allah için beşyüz } \\
\text { deve kurban etti. }\end{array}$ \\
\hline
\end{tabular}

aḥvāli: احولىى 


\begin{tabular}{|c|c|c|}
\hline 013 & $\begin{array}{l}\text { ismā'̄il oldı arada sevgülü } \\
\text { len tenālū'l-birra hattā tunfiḳū }{ }^{2}\end{array}$ & $\begin{array}{l}\text { O arada İsmail ona sevgili oldu. "Sevdiğiniz şey- } \\
\text { lerden (Allah yolunda) harcamadıkça iyiliğe asla } \\
\text { erişemezsiniz." }\end{array}$ \\
\hline $\begin{array}{c}{[18 \mathrm{a}]} \\
014\end{array}$ & $\begin{array}{l}\text { besledi ismācīli kim büyidi } \\
\text { geldi uyḳu ibrāhīme uyudı }\end{array}$ & $\begin{array}{l}\text { Ísmail'i besleyip büyüttü. İbrahim'e uyku geldi, } \\
\text { uyudu. }\end{array}$ \\
\hline 015 & $\begin{array}{l}\text { düşde gördi kim ana hạak söyledi } \\
\text { niçün ḳurbān eylemezsin sevdügün }\end{array}$ & $\begin{array}{l}\text { Düşünde, Allah'in ona: Niçin sevdiğini kurban et- } \\
\text { mezsin, dediğini gördü. }\end{array}$ \\
\hline 016 & $\begin{array}{l}\text { yüz devesi var-1dı gey sevgüli } \\
\text { şöyle kim cümle deveden sevgüli }\end{array}$ & $\begin{array}{l}\text { Bütün develerden daha çok sevdiği yüz devesi } \\
\text { vardı. }\end{array}$ \\
\hline 017 & $\begin{array}{l}\text { țaylayucak țurur ḳatār-1la yeder } \\
\text { vir șalavāt eyidem varup n’ider }\end{array}$ & $\begin{array}{l}\text { Sabahla birlikte kalkıp onları hayvan katarıyla } \\
\text { götürür. Bir salavat ver, gidip ne yaptığını söyle- } \\
\text { yeyim. }\end{array}$ \\
\hline 018 & $\begin{array}{l}\text { yüz deveyi kurbān eyledi halīl } \\
\text { ol gice yine nidā ḳıldı celīl }\end{array}$ & $\begin{array}{l}\text { Halil, yüz deveyi kurban etti. Fakat yüce Allah, o } \\
\text { gece yine ona seslendi. }\end{array}$ \\
\hline 019 & $\begin{array}{l}\text { yine düşde ḳurbān virmedüy } \\
\text { ḳavline bütün sözine țurmaduy }\end{array}$ & $\begin{array}{l}\text { Yine düşünde: (Sevdiğini) kurban etmedin, verdi- } \\
\text { ğin sözde durmadın, (dediğini gördü.) }\end{array}$ \\
\hline 020 & $\begin{array}{l}\text { yā halīl sen ḳavline țurmaz mısın } \\
\text { sevdügüy nesneyi terk itmez misin }\end{array}$ & $\begin{array}{l}\text { Ey Halil, sen sözünde durmaz mısın, sevdiğin şeyi } \\
\text { terk etmez misin? }\end{array}$ \\
\hline 021 & $\begin{array}{l}\text { yüz hyāṣ atı var-ıdı gör n'eyledi } \\
\text { șıra șıra ḳamusın bogazladı }\end{array}$ & $\begin{array}{l}\text { Yüz seçkin atı vardı, bak ne yaptı. Stra sıra (götü- } \\
\text { rüp) hepsini kesti. }\end{array}$ \\
\hline 022 & $\begin{array}{l}\text { halīl eydür işimi tamām işledim } \\
\text { sevdügümi cümlesin baġışladım }\end{array}$ & $\begin{array}{l}\text { Halil: Şimdi işimi tamamladım, sevdiklerimin } \\
\text { hepsini (Allah'a) bağışladım, dedi. }\end{array}$ \\
\hline 023 & $\begin{array}{l}\text { yine düşde gördi ki işlemedin } \\
\text { sevdügüni baya baġışlamadın }\end{array}$ & $\begin{array}{l}\text { Yine düşünde (Allah'ın): Yapmadın, sevdiğini } \\
\text { bana bağışlamadın, dediğini gördü. }\end{array}$ \\
\hline 024 & $\begin{array}{l}\text { țur örü nice yatursın uyan } \\
\text { hạakdır āhir bu sözi saya deyen }\end{array}$ & $\begin{array}{l}\text { Ayağa kalk, nasıl yatarsın, uyan. Allah'tır so- } \\
\text { nunda bu sözü sana diyen. }\end{array}$ \\
\hline 025 & $\begin{array}{l}\text { kurbān eyle ismācîli țur örü } \\
\text { saya ben virdim baya virgil girü }\end{array}$ & $\begin{array}{l}\text { Ayağa kalk ve İsmail'i kurban et. Sana (onu) ben } \\
\text { verdim, (onu) bana geri ver. }\end{array}$ \\
\hline 026 & $\begin{array}{l}\text { ‘aşḳımıza ḳurbān eyle og̉lı̄ı } \\
\text { țur örü yerine getür kavlini }\end{array}$ & $\begin{array}{l}\text { Oğlunu dostluğumuza kurban et. Ayağa kalk ve } \\
\text { verdiğin sözü yerine getir. }\end{array}$ \\
\hline
\end{tabular}

2 Âl-i İmrân 92: "Sevdiğiniz şeylerden Allah yolunda harcamadıkça iyiliğe asla erişemezsiniz." (Karaman et al. 2007: 61). 


\begin{tabular}{|c|c|c|}
\hline 027 & $\begin{array}{l}\text { ismāēildür sevdügüy bil yā halīl } \\
\text { bizim içün anı ḳurbān eylegil }\end{array}$ & $\begin{array}{l}\text { Ey Halil, sevdiğin İsmail'dir, bil. Bizim için onu } \\
\text { kurban et. }\end{array}$ \\
\hline $\begin{array}{c}{[18 b]} \\
028\end{array}$ & 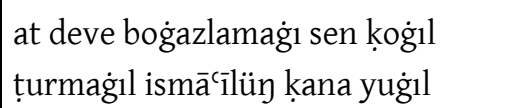 & $\begin{array}{l}\text { Sen, at ve deve kesmeyi bırak. Hiç bekleme, Is- } \\
\text { mail'i kan ile yıka. }\end{array}$ \\
\hline 029 & $\begin{array}{l}\text { çün halīlullāh uyandı uyḳudan } \\
\text { ditremek dutdı anı ol ḳorḳıdan }\end{array}$ & $\begin{array}{l}\text { Halil uykudan uyandiğı zaman onu korkudan tit- } \\
\text { reme tuttu. }\end{array}$ \\
\hline 030 & $\begin{array}{l}\text { yine yatdı ol düşi gördi yine } \\
\text { țurğll og̉lunı yuğıl ḳızıl ḳana }\end{array}$ & $\begin{array}{l}\text { Yine uyudu ve yine o düşü gördü: Ayağa kalk, oğ- } \\
\text { lunu kırmızı kan ile yıka. }\end{array}$ \\
\hline 031 & $\begin{array}{l}\text { ol gice yetmiş kezin gördi düşi } \\
\text { didi işlemek gerek işbu işi }\end{array}$ & $\begin{array}{l}\text { O gece yetmiş kez bu düşü gördü. Bu işi yapmak } \\
\text { gerek, dedi. }\end{array}$ \\
\hline 032 & $\begin{array}{l}\text { tanrınuy buyrugiddur țutmak gerek } \\
\text { ol ne dise ol sācat itmek gerek }\end{array}$ & $\begin{array}{l}\text { Tanrinin emridir, yerine getirmek gerek. } 0 \text {, ne } \\
\text { derse o zaman yapmak gerek. }\end{array}$ \\
\hline 033 & $\begin{array}{l}\text { uyhudan țurdı halīlullāh örü } \\
\text { ḳorḳıdan olmışdı beyzi șapșaru }\end{array}$ & $\begin{array}{l}\text { Halil, uykudan uyanıp ayağa kalktı. Korkudan } \\
\text { benzi sapsarı olmuştu. }\end{array}$ \\
\hline 034 & $\begin{array}{l}\text { uyhudan çün ibrāhīm belinledi } \\
\text { ismā'īlüm deyüben çoḳ aǵladı }\end{array}$ & $\begin{array}{l}\text { İbrahim uykudan korku ile sıçradı, İsmail'im di- } \\
\text { yerek çok ağladı. }\end{array}$ \\
\hline 035 & $\begin{array}{l}\text { eydür eger dir isem anasına } \\
\text { bencileyin od düşerse cānına }\end{array}$ & $\begin{array}{l}\text { Şöyle dedi: Eğer anasına dersem benim gibi içine } \\
\text { ateş düşer. }\end{array}$ \\
\hline 036 & $\begin{array}{l}\text { yigrek oldur ben sözi gizleyem } \\
\text { dügüne gidem deyü yol gözleyim }\end{array}$ & $\begin{array}{l}\text { En iyisi ben bu sözü gizleyeyim, düğüne gidece- } \\
\text { ğim diye yol gözleyeyim. }\end{array}$ \\
\hline 037 & $\begin{array}{l}\text { aldayım ismā̄îli alam gidem } \\
\text { iledüben halvetde kurbān ideyim }\end{array}$ & $\begin{array}{l}\text { İsmail'i kandırip alp gideyim, götürüp tenha bir } \\
\text { yerde kurban edeyim. }\end{array}$ \\
\hline 038 & $\begin{array}{l}\text { geldi ibrāhīm buyurdı hạācere } \\
\text { ismā'īlün yu başın șaçın țara }\end{array}$ & $\begin{array}{l}\text { İbrahim gelip Hacer'e buyurdu: İsmail'in başını } \\
\text { yıka ve saçını tara. }\end{array}$ \\
\hline 039 & $\begin{array}{l}\text { giydür aya arı arı țonları } \\
\text { digil aya kim ‘amāmın ḩoş șarın }\end{array}$ & $\begin{array}{l}\text { Ona temiz elbiseleri giydir ve sarığını güzel bir şe- } \\
\text { kilde sar, de. }\end{array}$ \\
\hline 040 & $\begin{array}{l}\text { bir eyü dost dügine oḳır beni } \\
\text { baya ḩoş kim dügine iletem anı }\end{array}$ & $\begin{array}{l}\text { Iyi bir dost beni düğüne davet eder, onu düğüne } \\
\text { götürmek benim için güzel bir iştir. }\end{array}$ \\
\hline 041 & $\begin{array}{l}\text { ne bilürdi miskīn anıy anası } \\
\text { og̉lını boġazlamaǵı iltesi }\end{array}$ & $\begin{array}{l}\text { Onun zavallı annesi, oğlunu kesmeye götürdü- } \\
\text { ğünü nereden bilirdi! }\end{array}$ \\
\hline
\end{tabular}




\begin{tabular}{|c|c|c|}
\hline $\begin{array}{c}{[19 a]} \\
042\end{array}$ & $\begin{array}{l}\text { țurdı geldi hoş șıg̉adı ellerin } \\
\text { ḳınaladı ismācīlüy ellerin }\end{array}$ & $\begin{array}{l}\text { Ayağa kalkıp ellerini sıvadı ve İsmail'in ellerini } \\
\text { kınaladı. }\end{array}$ \\
\hline 043 & $\begin{array}{l}\text { daḩı aldı eline bir ḩoş țarak } \\
\text { başını țaramagia ḳıldı yarak }\end{array}$ & $\begin{array}{l}\text { Ondan sonra eline güzel bir tarak aldı ve Ísmail' in } \\
\text { başını taramaya hazırllk yaptı. }\end{array}$ \\
\hline 044 & $\begin{array}{l}\text { țaradı başın oturdı sülük } \\
\text { șaçlarını eyledi iki bölük }\end{array}$ & $\begin{array}{l}\text { Annesine yaslanarak oturdu, annesi başını taradı } \\
\text { ve saçlarını iki bölük yaptı. }\end{array}$ \\
\hline 045 & $\begin{array}{l}\text { ismācīle țonlarını giydürür } \\
\text { atasıyıla ismācilili gönderir }\end{array}$ & $\begin{array}{l}\text { İsmail'e elbiselerini giydirir ve onu babasiyla } \\
\text { gönderir. }\end{array}$ \\
\hline 046 & $\begin{array}{l}\text { görüşüben öpdi hem iki gözin } \\
\text { ḳuçdı boynın yüzine urdı yüzin }\end{array}$ & $\begin{array}{l}\text { Onunla görüşüp iki gözünü öptü, boynuna sarıldl } \\
\text { ve yüzünü yüzüne sürdü. }\end{array}$ \\
\hline 047 & $\begin{array}{l}\text { eydür ayrılmaġıl ataydan ey cānım } \\
\text { dünyāda vāz ümiżim sen misin benim }\end{array}$ & $\begin{array}{l}\text { Ey canım, babandan ayrılma, dünyada birakıp } \\
\text { terk edemeyeceğim ümidim sensin benim. }\end{array}$ \\
\hline 048 & $\begin{array}{l}\text { gözlerim senüyle gördi cālemi } \\
\text { tīzrek gel yola baḳdurma beni }\end{array}$ & $\begin{array}{l}\text { Gözlerim dünyayı seninle gördü. Çabucak gidip } \\
\text { gel, gözümü yolda bırakma. }\end{array}$ \\
\hline 049 & $\begin{array}{l}\text { çün atası ismā̄īili aldı gider } \\
\text { vir șalavāt eydeyim varup n'ider }\end{array}$ & $\begin{array}{l}\text { Babası İsmail'i alıp gider. Bir salavat ver, gidip ne } \\
\text { yaptığını anlatayım. }\end{array}$ \\
\hline 050 & $\begin{array}{l}\text { çünki görünmez bulud ol aradan } \\
\text { gör ne ḳılur bu cihānı yaradan }\end{array}$ & $\begin{array}{l}\text { Ne zaman ki oradan bulut görünmez, bak bu dün- } \\
\text { yayı yaratan ne yapar? }\end{array}$ \\
\hline 051 & $\begin{array}{l}\text { geldi iblīs bir koca lacīn olup } \\
\text { fitnelige ol yavuz mel'ūn țolup }\end{array}$ & $\begin{array}{l}\text { Şeytan, lanetlenmiş bir yaşl olarak geldi. O kötü } \\
\text { ve lanetli şeytan fitnelikle doluydu. }\end{array}$ \\
\hline 052 & $\begin{array}{l}\text { geldi ismā‘îl anası ḳatına } \\
\text { söyledi çok kendüzinüy yanına }\end{array}$ & $\begin{array}{l}\text { İsmail'in anasinın huzuruna geldi ve onun ya- } \\
\text { nında çok sözler söyledi. }\end{array}$ \\
\hline 053 & $\begin{array}{l}\text { didi bu ne işdir kim işledüy } \\
\text { kendüzin kendü cayālin țaşladıy }\end{array}$ & $\begin{array}{l}\text { Bu ne iştir sen yaptın. Kendin, kendi evladını gur- } \\
\text { bete gönderdin, dedi. }\end{array}$ \\
\hline 054 & $\begin{array}{l}\text { oǵlını sen vir[ibi]dün }{ }^{3} \text { ölmege } \\
\text { öyle șandı vardı girü gelmege }\end{array}$ & $\begin{array}{l}\text { Sen, oğlunu öldürmeye gönderiyorsun. Gidip geri } \\
\text { gelecek mi sandın. }\end{array}$ \\
\hline 055 & $\begin{array}{l}\text { vardı ismācil dahıı gelmeyiser } \\
\text { görklü yüzin gözlerin görmeyiser }\end{array}$ & $\begin{array}{l}\text { İsmail, gidip bir daha gelmeyecek; sen, onun gü- } \\
\text { zel yüzünü bir daha görmeyeceksin. }\end{array}$ \\
\hline
\end{tabular}

3 viripdüy: Kelime metnin bağlamı gereği vir[ibi]düy şeklinde olmalıdır. 


\begin{tabular}{|c|c|c|}
\hline $\begin{array}{c}{[19 b]} \\
056\end{array}$ & $\begin{array}{l}\text { gözleriy görmeyiser görklü yüzin } \\
\text { ḳulaġıy işitmeye țatlu sözin }\end{array}$ & $\begin{array}{l}\text { Gözlerin onun güzel yüzünü görmeyecek, kulağın } \\
\text { tatlı sözlerini duymayacak. }\end{array}$ \\
\hline 057 & $\begin{array}{l}\text { ey nice zahmetle besledün anı } \\
\text { şimdi atası anda ḳanı }\end{array}$ & $\begin{array}{l}\text { Ey sen onu nice zahmetlerle büyüttün, şimdi ba- } \\
\text { bası nerede? }\end{array}$ \\
\hline 058 & $\begin{array}{l}\text { ey dirīgiā nāzenīn ol ismā̄îl } \\
\text { atası bog̀azlar anı ey gāāfil }\end{array}$ & $\begin{array}{l}\text { Ey gafil, eyvahlar olsun, o nazh İsmail' i babası ke- } \\
\text { secek. }\end{array}$ \\
\hline 059 & $\begin{array}{l}\text { kim ‘aceb ibrāhīme ol n'eyledi } \\
\text { döndi ismā̄île atası söyledi }\end{array}$ & $\begin{array}{l}\text { Acaba o, İbrahim'e ne yaptı? Babası dönüp İs- } \\
\text { mail'e söyledi. }\end{array}$ \\
\hline 060 & $\begin{array}{l}\text { ne șuçın bildi anı̀ ey bī-ḩaber } \\
\text { og̀lı ḳanın ibrāhīm niçün döker }\end{array}$ & $\begin{array}{l}\text { Ey habersiz, onun ne suçunu gördü, İbrahim oğ- } \\
\text { lunun kanını neden döker? }\end{array}$ \\
\hline 061 & $\begin{array}{l}\text { iblīs eydür işbu sözi bellü bil } \\
\text { hak buyurdı ḳurbān it oğlıy halîl }\end{array}$ & $\begin{array}{l}\text { Şeytan şöyle dedi: Bu sözü iyi bil; Allah, Halil'e oğ- } \\
\text { lunu kurban et diye buyurdu. }\end{array}$ \\
\hline 062 & $\begin{array}{l}\text { ismāc̄illi ol gerek kurbān ide } \\
\text { țutmaya ḥak buyrugunını pes n'ide }\end{array}$ & $\begin{array}{l}\text { Onun, İsmail'i kurban etmesi gerek, Allah buyru- } \\
\text { ğunu tutmayıp ne yapacak? }\end{array}$ \\
\hline 063 & $\begin{array}{l}\text { zīrā emir ḳıldı böyle ol celīl } \\
\text { dostıdır sözin șıyamaz bilgil haalīl }\end{array}$ & $\begin{array}{l}\text { Çünkü o yüce Allah, böyle buyurdu. 0, Halil'in } \\
\text { dostudur, onun sözünü kıramaz. }\end{array}$ \\
\hline 064 & $\begin{array}{l}\text { ismācîlün atasıdur ol bilür } \\
\text { ol halīldür yavuz işi ḳaçan ḳılur }\end{array}$ & $\begin{array}{l}\text { (Hacer): İsmail'in babasıdır, o bilir. O, Allah'in } \\
\text { dostudur, kötü işi nasıl yapar? }\end{array}$ \\
\hline 065 & $\begin{array}{l}\text { tayrı buyurdı ise ol oğlın } \\
\text { ḳurbān idüben döke anda ḳanın }\end{array}$ & $\begin{array}{l}\text { Tanrı buyurduysa o, oğlunu kurban ederek orada } \\
\text { kanını döker. }\end{array}$ \\
\hline 066 & $\begin{array}{l}\text { ey la`în çün dostı ola buyurıcı } \\
\text { sensin arada iblīs yol urucı }\end{array}$ & $\begin{array}{l}\text { Ey lanetlenmiş, o buyuran dostudur, şeytan olan } \\
\text { ve arada yol kesen sensin. }\end{array}$ \\
\hline 067 & $\begin{array}{l}\text { ḳulı buyuruġını haḳkuy eylesün } \\
\text { söyleme la`īn ḳoca ḳo söylesin }\end{array}$ & $\begin{array}{l}\text { Kulu, Allah'in buyruğunu yerine getirsin. Ey la- } \\
\text { netlenmiş ihtiyar sen söyleme, brrak o söylesin. }\end{array}$ \\
\hline 068 & $\begin{array}{l}\text { buyrug anı̀ ḳul anındur ol bilür } \\
\text { ol halîldir yavuz işi nite ḳılur }\end{array}$ & $\begin{array}{l}\text { Buyruk onun, kul onundur, o bilir. O, Allah'in dos- } \\
\text { tudur, kötü işi nasil yapar. }\end{array}$ \\
\hline 069 & $\begin{array}{l}\text { çünki anda bulmadı yavuz ol la'īn } \\
\text { işit imdi ol yavuz mel'ūn n'ider }\end{array}$ & $\begin{array}{l}\text { O kötü ve lanetlenmiş (şeytan) orada istediğini } \\
\text { bulamayınca şimdi ne yapar, dinle. }\end{array}$ \\
\hline
\end{tabular}

4 İkinci cümle metnin bağlamına uygun değildir. Buradaki karşllıklı konuşmada İsmail ve babası yoktur. Fakat yazmada bu şekilde geçmektedir. 


\begin{tabular}{|c|c|c|}
\hline $\begin{array}{c}{[20 \mathrm{a}]} \\
070\end{array}$ & $\begin{array}{l}\text { geldi ismācîl ḳatına söyledi } \\
\text { saya atạ bıçağını biledi }\end{array}$ & $\begin{array}{l}\text { İsmail'in yanına gelip şöyle der: Baban seni kes- } \\
\text { mek için bıçağını biledi. }\end{array}$ \\
\hline 071 & $\begin{array}{l}\text { şimdi dökiser senin ol ḳanıฑı } \\
\text { senden ötri aǵladı kes anạı }\end{array}$ & $\begin{array}{l}\text { O, senin kanını şimdi dökecek. Senden dolayı çok } \\
\text { ağladı, ananın (gözyaşlarını) dindir. }\end{array}$ \\
\hline 072 & $\begin{array}{l}\text { zīrā țuydı ol senin miskīn anay } \\
\text { seni boġazlamaġa iletdügin atay }\end{array}$ & $\begin{array}{l}\text { Çünkü senin o zavallı anan, babanin seni kes- } \\
\text { meye götürdüğünü duydu. }\end{array}$ \\
\hline 073 & $\begin{array}{l}\text { baya ünder }{ }^{5} \text { ismācîlüm ḳanıdur } \\
\text { uş beni virdi seni oḳur }\end{array}$ & $\begin{array}{l}\text { Bana, İsmail'im nerededir diye sordu. Şimdi beni, } \\
\text { seni çağırmak için gönderdi. }\end{array}$ \\
\hline 074 & $\begin{array}{l}\text { iletür atạ uş seni öldürmege } \\
\text { saya geldim uş bunı bildürmege }\end{array}$ & $\begin{array}{l}\text { Baban şimdi seni öldürmeye götürür. Bunu sana } \\
\text { bildirmek için geldim. }\end{array}$ \\
\hline 075 & $\begin{array}{l}\text { varmag்1l atạ ile döngil girü } \\
\text { saya didüm bu sözi gel dön girü }\end{array}$ & $\begin{array}{l}\text { Baban ile gitme, geri dön. Bu sözü sana söyledim, } \\
\text { gel geri dön. }\end{array}$ \\
\hline 076 & $\begin{array}{l}\text { döndi ismācīl didi kim ey ḳoca } \\
\text { söyledügi sözler senin nice }\end{array}$ & $\begin{array}{l}\text { İsmail dönüp: Ey ihtiyar, bu senin söylediklerin } \\
\text { nasıl sözlerdir. }\end{array}$ \\
\hline 077 & $\begin{array}{l}\text { benim atam ḳanımı niçün döker } \\
\text { çün halīl deyü hạak anı öger }\end{array}$ & $\begin{array}{l}\text { Benim babam kanımı niçin döksün, Allah onu Ha- } \\
\text { lil diyerek över. }\end{array}$ \\
\hline 078 & $\begin{array}{l}\text { ḳang்ı peyġāmber }{ }^{6} \text { cayālinüy ḳanın } \\
\text { döküben yere anı̀ aldı cānın }\end{array}$ & $\begin{array}{l}\text { Hangi peygamber evladının kanını yere dökerek } \\
\text { onun canını almıştır. }\end{array}$ \\
\hline 079 & $\begin{array}{l}\text { kim benim atam dahı döke ḳanım } \\
\text { bu ne macnīdür șuçum nedür benim }\end{array}$ & $\begin{array}{l}\text { Benim babam kanımı dökecekse bu ne anlama } \\
\text { gelmektedir, benim (buna sebep olacak) suçum } \\
\text { nedir? }\end{array}$ \\
\hline 080 & $\begin{array}{l}\text { dünyāyı benim gözüm-ile görür } \\
\text { ḳatı sever beni neye öldürür }\end{array}$ & $\begin{array}{l}\text { Dünyayı benim gözüm ile görür; beni çok sever, } \\
\text { neden beni öldürsün. }\end{array}$ \\
\hline 081 & $\begin{array}{l}\text { yüri git ayruk baya söylemegil } \\
\text { gitdi atam var beni eglemegil }\end{array}$ & $\begin{array}{l}\text { Yürü git, bana başka söz söyleme; atam önden } \\
\text { gitti, beni oyalama, git. }\end{array}$ \\
\hline 082 & $\begin{array}{l}\text { iblīs eydür seni bogazlar halīl } \\
\text { ḳaḳıdı țaş aldı atdı ismācīl }\end{array}$ & $\begin{array}{l}\text { Şeytan, Halil seni kesecek, deyince İsmail öfke- } \\
\text { lendi ve eline taş alarak ona attı. }\end{array}$ \\
\hline $\begin{array}{c}{[20 \mathrm{~b}]} \\
083\end{array}$ & $\begin{array}{l}\text { iblīsüy urdı çıkardı gözin } \\
\text { vir șalavāt şeyțāndan kurtılasın }\end{array}$ & $\begin{array}{l}\text { Şeytanın gözüne vurarak onun gözünü çıkardı. } \\
\text { Bir salavat ver, şeytandan kurtulasın. }\end{array}$ \\
\hline
\end{tabular}

5 ünder: أُونْرُ

6 peyg்ämber: بَيْغَمَبْرَ 


\begin{tabular}{|c|c|c|}
\hline 084 & $\begin{array}{l}\text { irdi ibrāhīme didi ey baba } \\
\text { bir ḳoca gördim șaḳalı gey ḳaba }\end{array}$ & $\begin{array}{l}\text { İbrahim'in yanına varınca: Ey baba, sakalı çok } \\
\text { büyük olan bir ihtiyar gördüm. }\end{array}$ \\
\hline 085 & $\begin{array}{l}\text { didi baya kim atạ iletür seni } \\
\text { öldürür bu dem döker senden ḳanı }\end{array}$ & $\begin{array}{l}\text { Bana dedi ki: Baban seni öldürmeye götürür ve } \\
\text { şimdi senin kanını döker. }\end{array}$ \\
\hline 086 & $\begin{array}{l}\text { iletür atạ uş seni öldürmege } \\
\text { geldüm uş bunı saya bildürmege }\end{array}$ & $\begin{array}{l}\text { Baban seni şimdi öldürmeye götürür, bunu sana } \\
\text { bildirmek için geldim. }\end{array}$ \\
\hline 087 & $\begin{array}{l}\text { ḳaḳıdım urdum çıkardım șag̉ gözin } \\
\text { şöyle itdüm bilmezem ey pāk-i dīn }\end{array}$ & $\begin{array}{l}\text { Kızıp öfkelendim, vurup să̆ gözünü çıkardım. Ey } \\
\text { dini temiz kimse, böyle yaptım, (doğru mu) bilmi- } \\
\text { yorum. }\end{array}$ \\
\hline 088 & $\begin{array}{l}\text { ibrāhīm didi ki ol iblīs idi } \\
\text { fitnesi çok mekri çok telbīs }{ }^{7} \text { idi }\end{array}$ & $\begin{array}{l}\text { İbrahim dedi ki: } 0 \text {, şeytand, fitnesi ve hilesi çok- } \\
\text { tur. }\end{array}$ \\
\hline 089 & 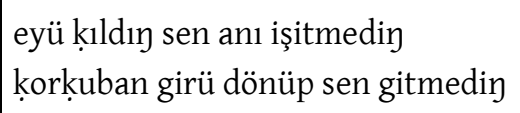 & $\begin{array}{l}\text { Sen, onu dinlemeyerek ve korkup geri dönmeye- } \\
\text { rek doğru yaptın. }\end{array}$ \\
\hline 090 & $\begin{array}{l}\text { ey nice kişileri ol azdurup } \\
\text { eyü yoldan çıḳarup yavız deyüp }\end{array}$ & $\begin{array}{l}\text { o, nice kişileri kandırarak ve kötü diyerek doğru } \\
\text { yoldan çıkardı. }\end{array}$ \\
\hline 091 & $\begin{array}{l}\text { seni diler idi dahı aldaya } \\
\text { uṣlu kişi iblīse ḳaçan uya }\end{array}$ & $\begin{array}{l}\text { Seni de kandırmak istedi. Akıll kişi şeytana nasıl } \\
\text { uyar? }\end{array}$ \\
\hline 092 & $\begin{array}{l}\text { tanrı etdi cānına la'net țaşın } \\
\text { eyü varup sen de çıḳardı̄ gözin }\end{array}$ & $\begin{array}{l}\text { Tanrı, onun canına lanet etti. Taşın gidip iyi vur- } \\
\text { muş, sen de onun gözünü çıkardın. }\end{array}$ \\
\hline 093 & $\begin{array}{l}\text { aldı ismācīlün elin eline } \\
\text { gider imdi düşdi șaḥrā yolına }\end{array}$ & $\begin{array}{l}\text { İsmail'in elini eline aldı, şimdi çöl yoluna düşerek } \\
\text { giderler. }\end{array}$ \\
\hline 094 & $\begin{array}{l}\text { gide gide irdiler bir halvete } \\
\text { tayrınuy buyruginı gerek țuta }\end{array}$ & $\begin{array}{l}\text { Gide gide tenha bir yere geldiler. Tanri'nın emrini } \\
\text { yerine getirmesi gerek. }\end{array}$ \\
\hline 095 & $\begin{array}{l}\text { eydür ey hạk cigerimdür n’ideyim } \\
\text { ismācīli nicesi terk ideyim }\end{array}$ & $\begin{array}{l}\text { Şöyle der: Ey Allah'ım, ciğerparemdir ne yapa- } \\
\text { yım, Ísmail'i nasıl terk edeyim. }\end{array}$ \\
\hline 096 & $\begin{array}{l}\text { ya boġazlamaǵa nice döyeyim } \\
\text { görklü yüzin nice ḳana boyayım }\end{array}$ & $\begin{array}{l}\text { Ya onu kesmeye nasıl dayanayım, güzel yüzünü } \\
\text { nasıl kana boyayayım. }\end{array}$ \\
\hline $\begin{array}{c}{[21 \mathrm{a}]} \\
097\end{array}$ & $\begin{array}{l}\text { öyle ider ne çāre itmek gerek } \\
\text { ismā'̄il bugün terk itmek gerek }\end{array}$ & $\begin{array}{l}\text { Şöyle söyler: Buna bir çare bulmak gerek, İsmail'i } \\
\text { bugün terk etmek gerek. }\end{array}$ \\
\hline
\end{tabular}

telbis: تَلْنِ 


\begin{tabular}{|c|c|c|}
\hline 098 & $\begin{array}{l}\text { çaldı yetmiş kez bıçaǵı og்lını } \\
\text { ditrer elleri kesmez bir ḳılını }\end{array}$ & $\begin{array}{l}\text { Bıçağı yetmiş kez oğluna sürdü, elleri titrer, tek } \\
\text { bir kılını kesemez. }\end{array}$ \\
\hline 099 & $\begin{array}{l}\text { ismā̄ill eydür şefā'at gözdedir } \\
\text { yüz yüze baḳma bıçak bir yerdedür }\end{array}$ & $\begin{array}{l}\text { İsmail: (Ey baba), merhamet gözdedir, yüzüme } \\
\text { bakma, bıçağı bir yere sür. }\end{array}$ \\
\hline 100 & $\begin{array}{l}\text { eydür ismā`îl atalık mührin getür } \\
\text { gözlerim baǵla yüzümi yere sür }\end{array}$ & $\begin{array}{l}\text { Baballk sevgini yerine getir, gözlerimi bağla ve } \\
\text { yüzümü yere doğru kapa. }\end{array}$ \\
\hline 101 & $\begin{array}{l}\text { atasını yüzüye kim bakmayın } \\
\text { dahıh hem yüregini yakmayın }\end{array}$ & $\begin{array}{l}\text { Babasının yüzüne bakmayın ve onun yüreğini } \\
\text { yakmayın. }\end{array}$ \\
\hline 102 & $\begin{array}{l}\text { mühri gözdedir baḳmam döymeyesin } \\
\text { beni boġazlamaġa ḳımasın }\end{array}$ & $\begin{array}{l}\text { Sevgi gözdedir, sana bakmam, dayanamazsin ve } \\
\text { beni kesmeye klyamazsin. }\end{array}$ \\
\hline 103 & $\begin{array}{l}\text { ol emānet bıçaǵı sen bile } \\
\text { hem elümi ḳatı bağla ip ile }\end{array}$ & $\begin{array}{l}\text { Sen, o emanet bıçă̆ı bile ve elimi sağlam bir ip ile } \\
\text { bağla. }\end{array}$ \\
\hline 104 & $\begin{array}{l}\text { olmasun bıçak çalarken el șalam } \\
\text { saya țokına yarın oda yanam }\end{array}$ & $\begin{array}{l}\text { Bıçağı sürerken sonra elimi uzatmayayım, eğer } \\
\text { sana dokunursa yarın cehennem ateşinde yana- } \\
\text { rım. }\end{array}$ \\
\hline 105 & $\begin{array}{l}\text { bir daḩı senden budur ki dilegim } \\
\text { anama gösterme ḳanlu gölmegim }\end{array}$ & $\begin{array}{l}\text { Senden bir isteğim de şudur ki: Kanl gömleğimi } \\
\text { anama gösterme. }\end{array}$ \\
\hline 106 & $\begin{array}{l}\text { çün vașiyyet ḳıldı çökdi dizin } \\
\text { bağladı atası nerges gözlerin }\end{array}$ & $\begin{array}{l}\text { Vasiyetini bitirdikten sonra dizlerinin üzerine } \\
\text { çöktü, babası nergis gözlerini bağladı. }\end{array}$ \\
\hline 107 & $\begin{array}{l}\text { elini ayag்ını çün baǵladı } \\
\text { ismāc̄il kendüye baḳdı ağladı }\end{array}$ & $\begin{array}{l}\text { Elini ayağını bağlayınca İsmail kendine bakıp ă̆- } \\
\text { ladı. }\end{array}$ \\
\hline 108 & $\begin{array}{l}\text { eydür ey baba ki ‘āṣi degülüm } \\
\text { ‘āșîler gibi niçün baǵlu elüm }\end{array}$ & $\begin{array}{l}\text { Ey baba, asi değilim, niçin asiler gibi elim bağll- } \\
\text { dir. }\end{array}$ \\
\hline 109 & $\begin{array}{l}\text { elüm ayaġım çözüp boġazlağıll } \\
\text { saya muțīc durur oğlun ismācīl }\end{array}$ & $\begin{array}{l}\text { Elimi ayağımı çözerek beni kes. Oğlun İsmail sana } \\
\text { tabidir. }\end{array}$ \\
\hline 110 & $\begin{array}{l}\text { çün çözdi ellerin virdi boġazın } \\
\text { halḳına çaldı bıçak yetmiş kezin }\end{array}$ & $\begin{array}{l}\text { Ellerini çözünce boğazını uzattı. (Ibrahim) bıçağı } \\
\text { yetmiş kez boğazına sürdü. }\end{array}$ \\
\hline 111 & $\begin{array}{l}\text { nice çaldı bıçaǵı hiç kesmedi } \\
\text { nice kessün ki çalab kesme dedi }\end{array}$ & $\begin{array}{l}\text { Bıçă̆ı ne kadar sürdüyse de hiç kesmedi. Nasıl } \\
\text { kessin ki Allah kesme dedi. }\end{array}$ \\
\hline $\begin{array}{c}{[216]} \\
112\end{array}$ & $\begin{array}{l}\text { pıçaġı kakakır halīi ç̧aldı țaşa } \\
\text { kesdi bıçak ol țaşı başdan başa }\end{array}$ & $\begin{array}{l}\text { Halil öfkelenerek bıçağı taşa vurdu. Bıçak, o taşı } \\
\text { baştan başa kesti. }\end{array}$ \\
\hline
\end{tabular}




\begin{tabular}{|c|c|c|}
\hline 113 & $\begin{array}{l}\text { eydür ey ‘āșī biçak kesdin țaşı } \\
\text { tamām niçün işlemediy bu işi }\end{array}$ & $\begin{array}{l}\text { Ey asi bıçak, taşı kestin, niçin bu işi yapıp tamam- } \\
\text { lamadın, dedi. }\end{array}$ \\
\hline 114 & $\begin{array}{l}\text { dile gelüp didi bıçak yā halīl } \\
\text { kesme didi bir ḳllın rabbü'l-celīl }\end{array}$ & $\begin{array}{l}\text { Bıçak dile gelip: Ey Halil, o yüce Allah bir kilını } \\
\text { bile kesme dedi. }\end{array}$ \\
\hline 115 & $\begin{array}{l}\text { buyruk anıydur buyuran ol durur } \\
\text { cümle anıy buyruġına ḳul durur }\end{array}$ & $\begin{array}{l}\text { Buyruk onundur, buyuran da odur. Herkes onun } \\
\text { buyruğuna kuldur. }\end{array}$ \\
\hline 116 & $\begin{array}{l}\text { ben ne șuç itdüm beni çaldın țaşa } \\
\text { yā ne ḳıldı çün ismācīl paşa }\end{array}$ & $\begin{array}{l}\text { Ey paşa, ben ne günah ettim de beni taşa vurdun } \\
\text { ve İsmail ne yaptt? }\end{array}$ \\
\hline 117 & $\begin{array}{l}\text { çün halīl dinledi bıçaḳdan cevāb } \\
\text { hak çalab cebrā̄īle ḳlldı hițāb }\end{array}$ & $\begin{array}{l}\text { Halil, bıçaktan bu cevabı duyduğu zaman yüce } \\
\text { Allah, Cebrail'e seslendi: }\end{array}$ \\
\hline 118 & $\begin{array}{l}\text { tez irgürgil ismā̄èle kurbānı } \\
\text { kurtar ol bize fidā olan cānı }\end{array}$ & $\begin{array}{l}\text { Çabuk kurbanı İsmail'e yetiştir. O bize kendini } \\
\text { feda etmek isteyen canı kurtar. }\end{array}$ \\
\hline 119 & $\begin{array}{l}\text { çünki böyle emir ḳıldı ol celīl } \\
\text { ḳoç getürdi ḳurbān içün cebrā̄îll }\end{array}$ & $\begin{array}{l}\text { O yüce Allah, böyle emredince Cebrail kurban et- } \\
\text { mek için koç getirdi. }\end{array}$ \\
\hline 120 & $\begin{array}{l}\text { hak nidā itdi ki tebdīli işiy } \\
\text { yerine geldi yā ibrāhīm düşüy }\end{array}$ & $\begin{array}{l}\text { Yüce Allah, Ey İbrahim işin değişti, düşün yerine } \\
\text { geldi, dedi. }\end{array}$ \\
\hline 121 & $\begin{array}{l}\text { halīl eydür kesmedim og̀lan başın } \\
\text { nice tamām eyledim ben dost işin }\end{array}$ & $\begin{array}{l}\text { Halil: Oğlumun başın kesmedim, ben dost işini } \\
\text { nasil tamamladım? }\end{array}$ \\
\hline 122 & $\begin{array}{l}\text { geldi nidā saya baş kes dimedin } \\
\text { ismā‘̄ilden sevgili kesgil didin }\end{array}$ & $\begin{array}{l}\text { Ses geldi: (Ey İbrahim) sana baş kes demedim, İs- } \\
\text { mail'den daha sevgili olanı kes dedim. }\end{array}$ \\
\hline 123 & $\begin{array}{l}\text { bizi seven gönüle nesne șıġmaya } \\
\text { dost dostdan nesne ayamaya }\end{array}$ & $\begin{array}{l}\text { Bizi seven gönle hiçbir nesne sığmaz, dostu dost- } \\
\text { tan hiçbir nesne mahrum edemez. }\end{array}$ \\
\hline 124 & $\begin{array}{l}\text { bizim içün oğluna çaldıy pıçak } \\
\text { dostlığında hażżetümüze oldı hak }\end{array}$ & $\begin{array}{l}\text { Bizim için oğluna bıçak sürdün, dostluğun katı- } \\
\text { mızda gerçek oldu. }\end{array}$ \\
\hline 125 & $\begin{array}{l}\text { tā halikin emrine fermān oldı } \\
\text { ismā̄ìlüy derdine dermān oldı }\end{array}$ & $\begin{array}{l}\text { Sonunda Allah'in emri yerine geldi, İsmail'in der- } \\
\text { dine derman oldu. }\end{array}$ \\
\hline 126 & $\begin{array}{l}\text { sen dahı̆ hakedan ‘ațā almayasın } \\
\text { tā pıçaġı nefsine çalmayasın }\end{array}$ & $\begin{array}{l}\text { Sen de Allah'tan lütufta bulunmayasın ve bıçağı } \\
\text { kendi nefsine çalmayasın. }\end{array}$ \\
\hline 127 & $\begin{array}{l}\text { çünki bunda ḩatim oldı bu kelām } \\
\text { vir șalavāt mușțafāya ve's-selām }\end{array}$ & $\begin{array}{l}\text { Bu söz, burada sona erdi. Mustafa'y a salavat ver. } \\
\text { Son söz budur. }\end{array}$ \\
\hline 128 & $\begin{array}{l}\text { fā'ilātün fā'ilātün fā'ilāt } \\
\text { mușțafānıy rūḥına vir șalavāt }\end{array}$ & $\begin{array}{l}\text { Fấ'ilâtün fầ'ilâtün fầ 'ilât. Mustafa'nin ruhuna bir } \\
\text { salavat ver. }\end{array}$ \\
\hline
\end{tabular}




\section{Dizinler}

\subsection{Gramatikal Dizin}

'acāyib (< Ar. 'acāib) Acayip, garip, tuhaf.

'a. 001

'aceb (< Ar. 'aceb) Şüphe, tereddüt, hayret ifade eden soru zarfi, acaba.

'a. 059

aç- Birleşik fiiller yapar.

cān kulag̀ın a. $\rightarrow$ cān: 001

ādem (< Ar. ādem < İbr.) İlk yaratılan insan ve ilk peygamber.

ā.+ e 003

ā.+ ün 004

ag̉la- Ağlamak.

a.- $d_{1} 034,071,107$

a.- $r$ idi 007

āhir (< Ar. āhir) Sonunda, nihayet.

ā. 024

aḥvāl (< Ar. aḥvāl) Durumlar, hâller.

a.+ $\mathrm{i} 001$

al- 1. Bir nesneyi elle veya araçla tutup yerinden kaldırmak.

a.-di $043,082,093$

2. Beraberinde götürmek veya getirmek.

a.- $\operatorname{am} 037$

a.- d1 049

3. Kabul etmek.

a.- mayasin 126

4. Birleşik fiiller yapar.

cānın a.- dı $\rightarrow$ cān: 078

alda- Aldatmak, kandırmak. a.- ya 091

a.- yım 037

‘ālem (< Ar. 'ālem) Dünya.

‘.a. $+\mathrm{i} 048$

‘amām (< Ar. 'amāme) Sarık.

ca.+ 1 10 039

ana Anne.

a.+ ma 105

a. + y 072

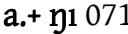

a.+ $\mathbf{s 1} 041,052$

a.+ sina 035

anca $\mathrm{O}$ kadar.

a. 011

anda Orada

a. $057,065,069$

andan Ondan sonra.

a. 002

anı Onu.

a. $027,029,040,057,058,077,089$

anıy Onun.

a. $041,060,068,078,115$

a.+ dur 068,115

aya Ona.

a. $003,010,015,039$

ara 1. Mesafe.

a.+ da 066

2. Vakit, zaman.

a.+ da 013

3. Yer.

a.+ dan 050

arı Temiz, pak. 
ar1 a. Tertemiz: 039

‘āṣi (< Ar. '̄ạși) Başkaldıran, isyan eden, isyankâr.

‘̄a. 108,113

$\bar{a}_{.}+\operatorname{ler} 108$

'aşk (< Ar. 'işk) Bir kimse veya bir şeye karşı duyulan çok kuvvetli sevgi ve bağlilık, dostluk.

‘.+ 1miza 026

at At (Binek hayvanı).

a. 028

a.+ 1021

at- Bir şeyi bir hedefe veya bir tarafa doğru firlatmak, atmak.

a.- d 1082

ata Baba.

a.+ $\mathrm{m} 077,079,081$

a. + y $070,072,074,075,085,086$

a.+ ydan 047

a.+ s1 049, 057, 058, 059, 106

a.+ sidur 064

a.+ sinı 101

a.+ s1yıla 045

a. oldı Baba olmak: 011

'aṭā (< Ar. 'ațā) İhsan, bağış.

ca. 126

atalık Baba olma durumu.

a. 100

aya- Yasaklamak, menetmek, mahrum etmek.

a.- maya 123

ayak Ayak.

a.+ $1 \mathrm{~m}$ (ayag்ım) 109

a.+ $\ln 1107$

‘ayāl (<Ar. 'iyāl) Evlat, çoluk çocuk. ca. 008,009

ca.+ inüy 078

ca.+ in 053

ayrıl- (Bir yer, şey veya kimseden) uzaklaşmak, onu geride bırakmak, ayrı düşmek.

a.- mag்1 047

ayruk Başka, gayrı, ayrı.

a. 081

azdur- Kışkırtmak, tahrik etmek.

a.- up 090

B

baba Baba, ata.

b. 084,108

baġışla- Vermek, ihsan etmek, bahşetmek.

b.- $\mathrm{d}_{1} 010$

b. $-\operatorname{dim} 022$

b.- madıy 023

bag̉la- İp, bağ veya başka bir araçla bir şeyi bir yere, diğer bir şeye veya birkaç şeyi birbirine tutturmak, bağlamak.

b. 100,103

b.- di 106, 107

göyül b.- r-1d1 $\rightarrow$ gönül: 007

bag̉lu İp veya başka bir araçla bir şeye, bir yere bağlanmış olan.

b. 108

bak- Gözleri bir şey üzerine çevirmek, bakmak.
b.- d 107
b.- ma 099
b.- mam 102
b.- mayin 101

bakdur- Bakmasına sebep olmak, baktırmak.

yola b.- ma $\rightarrow$ yol 048 
baya Bana.

b. $008,023,025,040,073,081,085$

baş 1. Baş, kafa.

b. 122

b.+ $\ln 038,044,121$

b.+ 1 n1 043

2. Uç, sınır.

başdan b.+ a Tamamiyla, bir uçtan bir uca: 112

başla- Bir işi yapmak üzere harekete geçmek, bir işe girişmek.

b.- yuban 002

bel Cinsi birleşme sırasında erkeklik organından gelen ve neslin devamını sağlayan salgı, bel suyu, sperma.

b.+ inden 004

belinle- Korku ile uykusundan sıçramak.

$$
\text { b.- di } 034
$$

bellü Belli, açık, aşikâr.

b. 061

ben Ben (Birinci tekil şahıs zamiri).

b. $025,036,116,121$

b. + i $040,048,073,080,081,102,116$

b.+ $\operatorname{im} 047,077,079,080$

bencileyin Benim gibi.

b. 035

beniz Yüz, yüzün rengi.

b. + i (beyzi) 033

besle- Yetiştirmek, büyütmek.

b.- di 014

b.- düy 057

beş yüz Beş yüz sayısı.

b. 012 bıçaḳ Bıçak. $\leftrightarrow$ pıçak.

b. $099,104,110,112,113,114$

b.+ dan 117

b.+1 (bıçağı) 098, 103, 111

b.+ $\ln 1$ (bıçağını) 070

b. çal- Bıçağı sürmek, bıçakla bir şeyi kesmeye çalışmak: 098, 104, 110, 111

bī-hyaber (<F. bì + Ar. haber) Habersiz, bilgisiz.

b. 060

bī-ḥisāb (<F. bī + Ar. hisāb) Sayısız, hesapsız.

b. old1 Sayısız olmak: 004

bil- Bir şey hakkında bilgisi olmak, o şeyi öğrenmiş bulunmak.

b. 027,061

b.- di 060

b.- gil 063

b.- mezem 087

b.- ür 064,068

b.- ürdi 041

bildür- Haber vermek, bildirmek.

b.- mege 074,086

bile- Kesici bir aleti bileği ile keskin duruma getirmek.

b. 103

b.- di 070

bir Bir, herhangi bir (Belirsizlik sıfatı).

b. $001,002,008,009,040,043,051,084$,

094, 098, 099, 105, 114

biri (Her hangi) Bir kimse, birisi.

b. 005

biz Biz (Birinci çokluk şahıs zamiri).

b.+e 118

b. + i 123 
b.+ $\operatorname{im} 027,124$

bog̉az Ağız boşluğundan sonra yiyeceklerin geçtiği, ağızla gırtlak arasındaki dar kısım.

$$
\text { b.+ } \ln 110
$$

boġazla- Eti yenecek hayvanı boğazını keserek öldürmek.

b.- d 021

b.- ġl 109

b.- maga 072, 096, 102

b.- mag்1 028,041

b.- r 058, 082

boya-Boyamak.

\section{b.- yım 096}

$$
\text { kana b. } \rightarrow \text { ḳan: } 096
$$

boyun Vücudun omuzlarla baş arasında kalan ve başı bedene bağlayan kısmı, boyun.

b.+ In (boynın) 046

bölük Ortadan iki yana ayrılmış saçın bir tarafı, belik.

b. eyledi Saçı iki yana ayırmak, ortadan ikiye ayırmak: 044

böyle (< bu+eyle) Böyle, bunun gibi, bu şekilde.

b. 063,119

bu 1. Bu (İşaret sıfatı). En yakında olan kimse veya şeyi işaret yoluyla belirtir.

b. $024,050,075,085,113,127$

2. Bu (İşaret zamiri).

b. 053

b.+ dur 105

bugün Bugün.

b. 097

bul-(Arayarak veya rastgele) Bir şey, bir kimse veya bir durumla karşılaşmak; görmek, elde etmek. b.- madi 069

bulud Bulut.

b. 050

buna Buna.

b. 079

bunda Burada.

b. 127

bunı Bunu.

b. 074,086

buyrug Buyrulan, emredilen şey, emir, hüküm. $\leftrightarrow$ buyruk.

b. 068

buyruk Buyrulan, emredilen şey, emir, hüküm. $\leftrightarrow$ buyrug.

b. 115

b.+ 1dur (buyrugidur) 032

b.+ Ina (buyrugiına) 115

b.+ 1nı (buyruginn) 067, 094

b.+ un1 (buyrugiun1) 062

b. eyle- Emri yerine getirmek: 067

b. țut- Emre itaat etmek: 062, 094

buyur- Bir şeyin yapılmasını kesin olarak bildirmek, emretmek.

b.- an 115

b. $-d_{1} 038,061$

b.- $d_{1}$ ise 065

buyurıc1 Emreden, buyuran, buyruk veren.

b. 066

bünyād (<F. bunyād) Yapı, bina.

b.+ $\ln 006$

bütün Eksiksiz, tam.

b. 019

büyi- Yetişmek, büyümek. 
b.- di 014

\section{C}

cān (< F. cān) 1. İnsanın kendi varlığı, yaşama, yaşayış, hayat.

C. +1118

c. $+1 \mathrm{~m} 047$

c.+ $\ln 078$

c.+ ina 092

c. al- Birini öldürmek: 078

2. İnsanın duygularını taşıyan iç âlemi, gönül, iç, yürek.

c. 001

c.+ ina 035

c.+ 1na od düş- İçi yanmak: 035

c. ḳulağın aç- Dikkat kesilmek: 001

cebrājīl (< Ar. cebrā'īl < İbr.) Dört büyük melekten biri, Allah'ın vahyini peygamberlere ulaştırmakla görevli olan melek.

c. 119

c. + e 117

celîl (< Ar. celìl) “Ululuk ve celâl sahibi, yüce, âli” anlamında esmâ-i hüsnâdan (Allah'ın en güzel isimlerindendir).

c. $018,063,119$

cevāb (< Ar. cevāb) Cevap, yanıt, karşılık.

c. 117

ciger (< F. ciger) Ciğer, bağır, gönül.

c.+ imdür 095

cihān (< F. cihān - cahān) Dünya, âlem.

c. + da 004

C.+ 1050

cümle (< Ar. cümle) Bütün, hep, hepsi, herkes.

c. 016,115

c. $+\sin 022$ çal- Vurmak, darbe indirmek.

ç.- arken 104

ç.- di 098, 111, 112

ç.- $\operatorname{din} 116,124$

ç.- mayasin 126

bıçaḳ ç. $\rightarrow$ bıçak: 098, 104, 110, 111

pıçak ç. $\rightarrow$ pıçaḳ: 112, 124, 126

çalab Tanrı, Allah.

ç. 111

ḥaḳ ç. $\rightarrow$ ḥaḳ: 117

çāre (< F. çāre) İstenen noktaya varmak, bir engeli aşmak için tutulması gereken yol, çıkar yol, çözüm yolu.

ç. it- Çare bulmak, çözmek: 097

çıḳar- 1. Bulunduğu yerden dışarı çıkmasını sağlamak.

ç.- di 083

ç.- dım 087

ç.- dig 092

2. Doğruluktan saptırmak.

ç.- up 090

yoldan ç. $\rightarrow$ yol: 090

çok Fazla, pek, çok.

ç. $034,052,088$

çök- Ayakları üstüne oturmak, çökmek.

ç.- di 106

çöz- (Bir şeyi) Bağlı, düğümlü, sarılı veya ilikli... durumdan çıkarmak, açmak, çözmek.

Ç.- di 110

ç.- üp 109

çün (<F. çūn/çun) Çünkü, için, dolayı, sebebiyle, mademki; ne zaman ki, gibi, -dı̆̆ı zaman, -ınca/ince vb. anlamlara gelen edat. $\leftrightarrow$ çünki. 
ç. $029,034,049,066,077,106,107,110$,

116,117

çünki (< F. çūn+ki) Çünkü, için, dolayı, sebebiyle, şundan dolayı, şu sebepten ki, zira, mademki; ne zaman ki, -dığı zaman, -ınca/-ince vb. anlamlara gelen edat. $\leftrightarrow$ çün.

ç. $050,069,119,127$

\section{D}

dahı "Fazla olarak, üstelik, daha, bile, de vb." anlamlara gelen kuvvetlendirme sözü. $\leftrightarrow$ de.

d. $043,055,079,091,101,105,126$

dāsitān (<F. dāstān) Hikâye, destan. ↔ destān.

d. 001

de- Söylemek, demek. $\leftrightarrow$ di-.

d.- di 111

d.- yen 024

d.- yü 036, 077

d.- yüben 034

d.- yüp 090

de Bağlama ve kuvvetlendirme edatı; da, de, dahı.

$$
\leftrightarrow \text { dahi. }
$$

d. 092

degül Değil (Olumsuzluk edatı).

d.+ üm 108

$\operatorname{dem}(<$ F. dem) An, zaman.

d. 085

derd (<F. derd) Dert, gam, keder, kaygı, üzüntü.

d.+ ine 125

dermān (< F. dermān) İlaç, şifa, deva.

d. 125

d. ol- Çare olmak: 125

destān (< F. dāstān > destān) Hikâye, destan. dāsitān.

d.- 1 ismācîl İsmail'in hikâyesi: 001 deve Sırtı bir veya iki hörgüçlü, bacakları ve boynu çok uzun yük ve binek hayvanı, deve.

d. 012,028

d.+ den 016

d.+ si 016

d.+ yi 018

di- Söylemek, demek. $\leftrightarrow$ de-.

d.- di 031, 053, 076, 084, 085, 088, 114

d.- $\operatorname{din} 122$

d.- düm 075

d.- gil 039

d.- medin 122

d.- $\mathrm{r}$ isem 035

d.- rdi 009

d.- se 032

dil Söz, laf, konuşma.

d.+ e gel- (Konuşma yetisi olmayan bir şey için) Konuşmaya başlamak; dillenmek: 114

dile- Dilemek, istemek.

d.- r idi 009, 091

d.- yüp 007

dilek İstek, arzu, talep, rica.

d.+ im (dilegim) 105

$\operatorname{dīn}(<\operatorname{Ar} \cdot \operatorname{din}) \quad$ İman, inanç, din.

pāk-i d. $\rightarrow$ pāk: 087

dịle- İşitmek, dinlemek, kulak vermek.

d. 001

d.- di 117

dirīgāa (<F. dirìg $\bar{a})$ Çok yazık, eyvahlar olsun, yazık.

d. 058

ditre- Hızlı hızlı hareketlerle sürekli kımıldamak, titremek.

d.- mek 029 


\section{d.- $\mathbf{r} 098$}

diz Bacakta uylukla baldırın birleștiği oynak kısım, diz.

d. + in 106

dost (<F. dōst/dūst) Dost, arkadaş.

d. $040,121,123$

d.+ dan 123

d.+ 1dir 063

d.+ 1 ol- Aralarında sevgi ve yakınlık olmak, dost olmak: 066

dostlık (< F. dōst/dūst + T. -lık) Çıkar ilişkisine dayanmaksızın kişilerin birbirlerine karşı duydukları bağlılık.

d.+ inda (dostlı̈̇nda) 124

dök- (Göz yaşı, kan, ter vb.) Akıtmak, dökmek.

d.- e 065,079

d.- er 060, 077, 085

d.- iser 071

d.- üben 078

kan d. $\rightarrow$ kan: 060, 065, 071, 077, 078, 079, 085

dön- Geri gitmek veya geri gelmek, avdet etmek, dönmek.

d. 075

d.- di 059, 076

d.- gil 075

d.- üp 089

döy-Dayanmak, tahammül etmek, katlanmak.

d.- eyim 096

d.- meyesin 102

durur (Bildirme)-dır/-dir (dur- fiilinin hâl kipi. 14. yüzyıldan sonra arkaizm ya da bir beytin boş yerini doldurmak için kullanılırdı).

d. 109,115 dut- (Ağrı, sanc1, hastalık vb.) Musallat olmak, yakalamak.

d. - d1 029

dügin Evlenme veya sünnet dolayısıyla yapılan büyük eğlence. $\leftrightarrow$ dügün

d. + e 040

dügün Evlenme veya sünnet dolayısıyla yapılan büyük eğlence. $\leftrightarrow$ dügin.

d. e e 036

dün Gece.

d. ü gün Gece gündüz: 011

dünyā (< Ar. dunyā) Dünya, âlem, içinde yaşadığımız yer, yerküre.

d. + da 047

d. + y1 080

düş Uyurken zihinde beliren hayaller ve düşünceler, rüya.

d.+ de 015, 019, 023

d.+ i 030, 031

d.+ üy 120

düş- 1. Başını alıp gitmeye koyulmak, kendini -e atmak.

d.- di 093

yolina d. $\rightarrow$ yol: 093

2. Birleşik fiiller yapar.

d.- erse 035

cānına od d. $\rightarrow$ cān: 035

E

eger (< F. ger/eger) Ĕ̆er, şayet. (Şart anlamını güçlendirmek için şart cümlelerinin başına getirilir).

e. 035

egle- Alıkoymak, geciktirmek, vakit geçirtmek, durdurmak. 


$$
\text { e.- megil } 081
$$

el Kolun, bilek mafsalından itibaren avuç ve parmakları içine alan ve iş görmeye, tutmaya yarayan kısmı.

e.+ in 093

e.+ ine 043, 093

e.+ ini 107

e.+ leri 098

e.+ lerin 042,110

e.+ üm 108, 109

e.+ ümi 103

e. șal- El uzatmak: 104

emānet (< Ar. emānet) Korunmak için birine bırakilan şey.

e. 103

emir (< Ar. emr) Emir, buyruk.

e.+ ine (emrine) 125

e. ḳıl- Bir kimseden bir şey yapmasını istemek, buyurmak, emir vermek: 063, 119

enbiyā (< Ar. enbiyā) Peygamberler, nebiler.

\section{e.+ niy 005}

et- Türkçede birçok kelimenin sonuna gelerek birleşik fiiller teşkil eden, sonuna geldiği kelimeye göre değişik fonksiyonları olan, geçişli veya geçişsiz fiiller, ayrıca çeşitli deyimler yapan fiil.

e.- di 092

lacnet e. $\rightarrow$ la'net: 092

evliyā (< Ar. evliyā) Ermişler, veliler.

e. 004

ey (İsimden önce hitap ünlemi) Ey, hey, bre, be vb. anlamlara gelir.

e. $006,008,047,057,058,060,066,076$,

084, 087, 090, 095, 108, 113 eyit- Demek, söylemek. $\leftrightarrow$ eyt-.

e.- em (eyidem) 017

eyle- "Yapmak, etmek, kılmak" anlamında yardımc1 fiiller yapar.

e. 025,026

e.- di 018, 044

e.- $\operatorname{dim} 121$

e.- gil 027

e.- $\operatorname{mezsin} 015$

e.- sün 067

e.- yem 008

bölük e. $\rightarrow$ bölük: 044

buyuruġını e. $\rightarrow$ buyruk: 067

kurbān e. $\rightarrow$ kururban: 008, 015, 018, 025, 026, 027

tamām e. $\rightarrow$ tamām: 121

eyt-Demek, söylemek. ↔ eyit-.

e.- eyim (eydeyim) 049

e.- ür (eydür) 008, 022, 035, 047, 061, 082, 095, 099, 100, 108, 113, 121

eyü İyi.

e. $040,090,092$

e. ḳ1l- İyi yapmak, doğru yapmak: 089

F

fermān $\quad(<F$. fermān) Emir, buyruk.

f. ol- Emir olmak, buyruk olmak: 125

fidā (< Ar. fidā) Bir şey uğrunda değerli bir şeyden vazgeçme, uğruna verme.

f. ol- Feda olmak, bir şey uğrunda değerli bir şeyden vazgeçmek: 118

fitne (< Ar. fitne) Karışıklık, fesat, kargaşalık.

f.+ lige 051

f.+ si 088 
G

ġāfil (< Ar. ġāfil) Çevresinden ve gerçeklerden habersiz olan, gaflet içinde bulunan, dalgın, dikkatsiz ve düşüncesiz (kimse).

g. 058

garāyib (< Ar. ġarā’ib) Garîbeler, şaşılacak tuhaf şeyler, işitilmemiş duyulmamış olaylar.

g. 001

gel-1. (-den, -e) Gelmek, varmak, ulaşmak.

g. 048,075

g.- di 038, 042, 051, 052, 070

g- $\operatorname{dim} 074$

g.- düm 086

2. Bulunduğu yerden ayrılıp geri dönmek, avdet etmek.

g.- mege 054

g.- meyiser 055

3. Doğmak, dünyaya gelmek.

g.- di 004

4. (Koku, ses ve sesle ilgili şeyler için) Duyulmak.

g.- di 122

5. Birleşik fiiller yapar.

g.- di 014,120

g.- üp 114

uyḳu g. $\rightarrow$ uyḳu: 014

yerine g. $\rightarrow$ yer: 120

dile g. $\rightarrow$ dil: 114

gerek- Lazım olmak, gerekmek.

g. 031, 032, 062, 094, 097

getür- 1. (Daha uzak bir yerden) Bulunulan yere gelmesini sağlamak, gelmesine sebep olmak, iletmek, nakletmek.

g.- di 119
2. Sağlamak, yerine getirmek.

g. 100

3. (Yardımcı fiil olarak) ... etmesini sağlamak, ... duruma gelmesine sebep olmak.

g. 026

yerine g. $\rightarrow$ yer: 026

gey Çok, pek çok, gayet.

g. 016,084

gibi Gibi, benzer (Benzetme edat1).

g. 108

gice Gece.

g. $006,010,018,031$

girü Arkaya doğru.

g. $025,054,075,089$

git- 1. (Bir yerden bir yere) Hareket etmek, gitmek.

g. 081

g.- di 081

g.- em (gidem) 036, 037

g.- er 049, 093

g.- medin 089

gide g.- e Gitmeye devam ederek, gittikçe: 094

2. (Söz için) Sürmek, devam etmek.

g.- elüm (gidelüm) 002

giydür- Giydirmek, giyinmesini sağlamak.

g.- ür 039, 045

gizle- Saklamak, gizlemek.

g.- yem 036

gölmek Gömlek.

g.+ im (gölmegim) 105

gönder- Göndermek, yollamak, gitmesini sağlamak.

g.- ir 045 
gönül Gönül, kalp, iç.

g.+ den 009

g.+ e 123

g. bağla- İçten severek bağlanmak: 007

gör- Görmek, bakmak, algılamak, göz ile seçmek.

g. 021,050

g.- di 015, 023, 030, 031, 048

g.- $\operatorname{dim} 084$

g.- meyiser 055, 056

g.- ür 080

görklü Güzel, gösterişli, görkemli.

g. $055,056,096$

görün- Görünür hâlde olmak, görülebilecek durum veya nitelikte olmak.

g.- $\operatorname{mez} 050$

görüş- Karşı karşıya gelip konuşmak, birbirini görmek; görüşmek.

g.- üben 046

göster- (Birinin) Görmesini sağlamak.

g.- me 105

göz Göz, görme organ1.

g.+ dedir 099, 102

g.+ in $046,083,087$

g.+ in 092

g.+ lerim 048,100

g.+ lerin 055,106

g.+ lerin 056

g.+ üm-ile 080

gözle- Gözlemek, takip etmek, beklemek.

g.- yim 036

yol g. $\rightarrow$ yol: 036

gün Gündüz. dün ü g. $\rightarrow$ dün: 011

\section{$\mathrm{H}$}

hāacer (k.a.) Hacer, İbrahim peygamberin karısı, Hz. İsmail'in de annesidir.

h.+e 038

ḥācet (< Ar. ḩācet) Allah'tan veya büyük bir makamdan yerine getirilmesi, gerçekleştirilmesi istenen dilek.

h.+i 012

hak (< Ar. hakk) 1. Allah, Cenâbıhak, Tanrı, Hudâ. hakẹ.

h. $008,010,015,061,062,077,095,120$

h.+ dan 007, 126

h.+ dir 024

ḥ. çalab Allahü Tealâ: 117

ḥ. te`alā Yüce Allah: 003

2. Doğru, gerçek.

h. ol-Gerçek olmak: 124

hakạ (< Ar. hakk) Allah, Cenâbıhak, Tanrı, Hudâ. hak.

h..+ -1çun 012

h.+ un 067

halik (< Ar. hālik) Yaratan, yaratıcı.

h.. in 125

halîl (k.a.) "Samimi dost" anlamındadır. İbrahim aleyhisselâm.

h. $011,018,020,022,027,061,063,077$,

$082,112,114,117,121$

h.+ dir 068

h.+ dür 064

halīlullāh (k.a.) "Halis, sadık dost" anlamındadır. İbrahim aleyhisselâm.

h. 029,033 
h. 1 şāh-1 muhterem Saygıdeğer hükümdar Halilullâh: 005

ḥalk (< Ar. halk) Boğaz.

h.+ $\operatorname{lna} 110$

halvet (< Ar. halvet) Kimsenin bulunmadığı 1ssız yer.

h.+ de 037

h.+e 094

ḩāṣ (< Ar. hāsṣ̣s) Özel, seçkin.

h. 021

hatim ( $<$ Ar. hatm) Bitirme, sona erdirme, tamamlama.

h. ol- Sona ermek, tamamlanmak: 127

hazāa (< Ar. hažā) "Bu, şu, o" anlaminda olup Türkçede kalıplaşmış bazı Arapça kullanılışların içinde geçer.

h. 001

hażret (< Ar. hażret) 1. Bir büyük zattan bahsedilirken isim yerine kullanılır.

h..+e 011

2. (Bilhassa Allah için) Kat, huzur.

h..+ ümüze 124

hem (<F. hem) Hem, üstelik, ayrıca, şu da var ki, aynı zamanda; ve de, dahi.

h. $046,101,103$

her (<F. her) (Belirsizlik sıfatı olarak).

h. 006

hiç (<F. hiç) Hiç, hiçbir, asla, katiyen.

h. 111

hițāb (< Ar. hițāb) Hitap, seslenme sözü.

h. kıl- Söz söylemek, seslenmek, hitap etmek: 117

hoca (< F. hāace) Dinî hizmetlerde görevli kimse, din görevlisi, hoca.

h. 006 hoş (<F. hoş) İyi, güzel, hoş, latif.

h. $002,009,039,040,042,043$

$$
\text { I }
$$

'iş̣̣ (< Ar. 'işk) Aşk.

c1.-1la 002

\section{I}

i- Aslı Eski Türkçede ermek iken irmek > imek olarak değişen ve kökü eriyip bugün sadece "şu veya bu durumda bulunmak" anlamındaki idi, imiş, ise, iken şekilleri kullanılan fiil, isim fiili, ek fiil, imek fiili.

ağlar i.- di 007

diler i.- di 009, 091

iblīs i.- di 088

telbīs i.- di 088

uyhuya varmaz i.- di 007

buyurdı i.- se 065

dir i.- sem 035

iblīs (< Ar. iblìs < İbr.) Şeytan.

i. $051,061,066,082$

i.+ e 091

i. idi 088

i.+ ün 083

ibrāhīm (k.a.) İbrahim peygamber aleyhisselâm. Hz. İsmail'in babasıdır.

i. $034,038,060,088,120$

i.+ e $014,059,084$

i.+ ün 012

içün İçin, diye.

i. $027,119,124$

iki İki sayısı.

i. 044,046

ile İle (Bağlaç). 


$$
\text { i. } 075,103
$$

ilet - Götürmek veya getirmek, ulaştırmak, eriştirmek.

\section{i.- dügin 072}

i.- em 040

i.- üben (iledüben) 037

i.- ür 074, 085, 086

ilt-Götürmek, iletmek.

i.- esi 041

imdi Şimdi.

i. 069,093

ip Dokuma malzemesinden yapılan ve bağlamak için kullanılan, çeşitli kalınlıkta bükülmüş sicim, ip.

i. 103

ir- Belli bir yere, bir noktaya varmak, vâsıl olmak, erişmek.

i.- di 084

i.- diler 094

irgür- Ulaştırmak, eriştirmek.

i.- gil 118

ismācīl (k.a.) Hz. İsmail, İbrahim peygamberin oğludur.

i. 013, 052, 055, 058, 070, 076, 082, 097,

$099,100,107,109,116$

i.+ den 122

i.+ dür 027

i.+e $011,045,059,118$

i.+ i 010, 014, 025, 037, 045, 049, 062, 095

i.+ üm 034, 073

i.+ ün 028, 038, 042, 064, 093, 125

$$
\text { destān-1 i. } \rightarrow \text { destān: } 001
$$

iş Bir maksatla yapılan faaliyet, çalışma, amel. i.+ $\operatorname{dir} 053$

i.+ i 031, 064, 068, 113

i.+ imi 022

i. + in 121

i. + in 120

işbu Bu, işte bu.

i. 031,061

işit- Duymak, dinlemek, işitmek.

i. 069

i.- medin 089

i.- meye 056

işle- Yapmak, işlemek.

i.- dün 053

i.- $\operatorname{dim} 022$

i.- medin 023, 113

i.- mek 031

tamām i. $\rightarrow$ tamām: 022

it- 1. Yapmak, etmek, kılmak, işlemek.

i.- mek 032

2. Türkçede birçok kelimenin sonuna gelerek birleşik fiiller teşkil eden, sonuna geldiği kelimeye göre değişik fonksiyonları olan, geçişli veya geçişsiz fiiller, ayrıca çeşitli deyimler yapan fiil. "Yapmak, etmek, kılmak" anlamlarında birleşik fiiller yapar.

i. 061

i.- di 012,120

i.- düm 087, 116

i.- e (ide) 062

i.- er (ider) 097

i.- eyim (ideyim) 037, 095

i.- mek 097

i.- mez misin 020 
i.- üben (idüben) 065

çāre i. $\rightarrow$ çāre: 097

kurbān i. $\rightarrow$ kurbān: 012, 037, 061, 062, 065

nidā i. $\rightarrow$ nidā: 120

öyle i. $\rightarrow$ öyle: 097

șuç i. $\rightarrow$ șuç: 116

şöyle i. $\rightarrow$ şöyle: 087

terk i. $\rightarrow$ terk: 020, 095, 097

\section{$\mathrm{K}-\mathrm{K}$}

ḳaba Büyük, iri, kalın.

k. 084

ka'be (< Ar. ka`be) Bütün müslümanların kıblesi ve ziyaret yeri olan Mekke şehrindeki mukaddes bina, beytullah.

k.+ nin 006

kaçan Ne vakit, ne zaman ki.

k. 091

k. ḳ1- Nasıl yapmak: 064

ḳaḳı- Birine yaptığı işin doğru olmadığını, beğenilmediğini sert sözlerle bildirmek; azarlamak; paylamak.

k..- d 082

k..- $\operatorname{dım} 087$

k..- $\mathbf{r} 112$

ḳamu Bütün, her.

k..+ $\sin 021$

kan Kan.

k..+a 028, 030, 096

k..+1 1085

k.+ $1 \mathrm{~m} 079$

k.+ $1 \mathrm{~m} 1077$

k..+ in 060, 065, 078

k..+191 071 k..+ a boya- Kana boyamak, yaralayarak kan içinde bırakmak: 096

k..+ a yu- Kana boyamak, kan içinde bırakmak: 028, 030

k..+ 1 dök- Bir kimseyi yaralamak veya öldürmek, cana kiymak: 060, 065, 071, 077, 078, 079, 085

kang̀ Hangi.

k. 078

kanı Hani, nerede.

k. 057

k..+ dur 073

ḳanlu Kan bulaşmış, kanlı.

k. 105

kat Huzur, yan, ön.

k.+ ina 052, 070

katār (< Ar. katār) Birbiri arkasına sıralanmış hayvan veya taşıt dizisi, katar.

k..+ 1 la 017

katı Çok, pek, pek çok.

k. 080,103

kavl (< Ar. kavl) Sözleşme, anlaşma.

k.. ine 019,020

k..+ ini 026

k.+ ine țur-Sözünde durmak, sözünü tutmak: 020

kelām (< Ar. kelām) Söz.

k. 127

kendü Kendi, kendisi.

k. 053

k.+ ye 107

kendüz Kendisi, şahsı, kişiliği.

k.+ inüy 052

k.+ in 053 
kerem (< Ar. kerem) Cömertlik, alçak gönüllülük.

sulțān-1 k. $\rightarrow$ sulțān: 005

kes- (Bıçak, makas, balta vb. bir araçla) Kesmek, ikiye ayırmak.

k. 071,122

k.- di 112

k.- $\operatorname{din} 113$

k.- gil 122

k.- me 111,114

k.- medi 111

k.- medim 121

k.- $\operatorname{mez} 098$

k.- sün 111

kez Defa, kere, sefer.

k. 098

k.+ in 031,110

kı1- "Etmek, kılmak, yapmak" anlamında yardımc1 fiiller yapar.

k..- d1 003, 018, 043, 050, 063, 106, 116, 117, 119

k.- dilar 003

k.- $\operatorname{din} 089$

k.- ur 064, 068

emir k.. $\rightarrow$ emir: 063, 119

hițāb k. $\rightarrow$ hițāb: 117

ne k. $\rightarrow$ ne: 050,116

nidā ḳ. $\rightarrow$ nidā: 018

vașiyyet ḳ. $\rightarrow$ vașiyyet: 106

vücūd $k$. $\rightarrow$ vücūd: 003

yaraḳ ḳ. $\rightarrow$ yaraḳ: 043

sücūd ḳ. $\rightarrow$ sücūd: 003

eyü ḳ. $\rightarrow$ eyü: 089

ḳaçan ḳ. $\rightarrow$ ḳaçan: 064 nite $\mathbf{k} . \rightarrow$ nite: 068

ḳ1 Kıl, tüy.

k.+ $\ln 114$
k..+ $\ln 1098$

kınala- Kına sürmek, kına ile boyamak.

k..- d 042

ḳırḳ Kırk sayısı.

k. 010

ḳy- İçi sızlamadan öldürmek, canına kastetmek.

k.- $\operatorname{masin} 102$

ḳııl Parlak kırmızı renk.

k. 030

ki Ki (Bağlama edatı).

k. $023,088,105,108,111,120$

kim Kim, ki (Bağlama edatı).

k. 014, 015, 016, 039, 040, 053, 059, 076, 079, 085, 101

kişi İnsan, kimse, şahıs.

k. 091

k.+ leri 090

kitāb (< Ar. kitāb) Kitap, eser.

k.+ da 006

ḳo- Koymak, bırakmak, terk etmek.

k. 067

k.- $\dot{\text { gll }} 028$

ḳoca Yaşlı, ihtiyar.

k. $051,067,076,084$

ḳoç Damızlık erkek koyun, koç.

k. 119

korḳ- Korkuya kapılmak, korku duymak, ürkmek, çekinmek.

k.- uban 089 
ḳorḳı Bir tehlike veya tehlike ihtimali karşısında duyulan ürkütücü duygu, korku.

$$
\text { k..+ dan 029, } 033
$$

kuç- Kucaklamak, bağrını basmak.

$$
\text { k..- di } 046
$$

ḳul Allah tarafından yaratılmış olan insan, abd.

k. 068,115

k..+1 1067

kulaḳ Kulak, işitme organı.

ḳ.+1 1 (ḳulaġı) 056

cān ḳ.+ In aç- $\rightarrow$ cān: 001

kurbān (< Ar. kurbān) 1. Allah yolunda kesilen hayvan.

k. 012,018

k..+ 1118

k. it- (Bir hayvanı) Kurban niyetiyle kesmek: 012

k. eyle- Dinin emrini yerine getirmek için usulüne göre bir hayvanı kesmek: 018

2. Yüksek bir amaç uğrunda bir şeyi veya kendini feda etme.

k. 008, 015, 019, 025, 026, 027, 037, 061, 062, 065, 119

k. it- (Bir kimse veya şeyi) Bir uğurda feda etmek: 037, 061, 062, 065

k. eyle- (Bir kimse veya şeyi) Bir uğurda feda etmek: 008, 015, 018, 025, 026, 027 k. vir- (Bir kimse veya şeyi) Bir uğurda feda etmek: 019

kurtar- Kurtulmasını sağlamak; bir canlıyı tehlikeden, mahvolmaktan, helak olmaktan uzaklaştırmak.

k. 118

kurtıl- (Bir tehlikeden, sıkıntılı bir durumdan) Sıyrılmak, uzaklaşmak, selamete çıkmak.

k.- $\operatorname{asin} 083$

\section{$\mathrm{L}$}

la'īn (< Ar. la'in $)$ Lanetlenmiş, lanetli, melun.

$1.066,067,069$

1. ol- Lanetlenmiş olmak: 051

la'net ( $<$ Ar. la'net) Allah'n rahmetinden, af ve merhametinden mahrum olma.

1. et- Allah'in rahmetinden mahrum kalmasinı dilemek, beddua etmek: 092

M

ma`nì (< Ar. ma nāa) Anlam, mana.

m.+ dür 079

mekr (< Ar. mekr) Hile, düzen, aldatma.

m.+i 088

melā’ik (< Ar. melā’ik) Melekler, melâike.

m.+ ler 003

mel'ūn $(<$ Ar. mel' $\bar{u} n)$ Lanetlenmiş, lanetli.

m. 051,069

miskīn (< Ar. miskīn) Âciz, zavallı (kimse).

m. 041,072

muhterem (< Ar. muhterem) Saygı gösterilen, saygıya layık olan, saygıdeğer.

halīlullāh-1 şāh 1 m. $\rightarrow$ h halīlullāh: 005

mușțafā (k.a.) Hz. Muhammed.

m.+ nin 128

m.+ ya 127

muțī (< Ar. muțīi $)$ Uyan, itaat eden, boyun eğen, tâbi olan (kimse).

m. 109

mühr (<F. mihr) Sevgi, dostluk.

m.+ i 102

m.+ in 100

\section{N}

n'eyle- $(<n e+e y l e-)$ Ne yapmak, ne etmek. 
n.- di 021, 059

n.- yüp 009

n'it- $(<n e+i t-)$ Ne etmek, ne yapmak.

n.- e (n'ide) 062

n.- er (n'ider) 017, 049, 069

n.- eyim (n'ideyim) 095

nāzenīn (<F. nāzenīn) İşveli, cilveli, nazlı.

n. 058

ne Ne, hangi şey.

n. $032,041,050,053,060,097,116$

n.+ dür 079

n. ḳıl- Ne yapmak:116

nefs (< Ar. nefs) Bir kimsenin kendi öz varlığı, öz benliği, kişiliği.

n.+ ine 126

nerges (< F. nergis) Nergis çiçeği, edebi anlamda sevgilinin gözüne benzetilir.

n. 106

nesne $(<n e+i s e+n e)$ Şey, nesne.

n. 123

n.+ yi 020

neye Bir olayın amacinı veya sebebini sormakta kullanilan zarf, neden, niye.

n. 080

nice 1. Çok, pek çok, birçok.

n. $057,090,111$

2. Nasil.

n. $024,076,096,111,121$

n.+ si 095

niçün $(<n e+i c ̧ u ̈ n)$ Bir şeyin sebebini ve amacını sormak amacıyla kullanılan "neden, hangi sebeple, hangi sebepten ötürü?" anlamında soru zarfi.

n. $015,060,077,108,113$ nidā (< Ar. nidā) Seslenme, bağırma, çağırma.

n. 122

n. it- Seslenmek: 120

n. ḳ1-Seslenmek: 018

nite Nas1l.

n. ḳıl- Nasıl yapmak: 068

\section{0}

od Ateş.

o.+ a yan- Ateşte yanmak: 104

cānına o. düş- $\rightarrow$ cān: 035

og̉lan Erkek çocuk.

o. 121

og̉ul Erkek evlat, genç delikanlı.

0.+ 1 (og li) 060

o.+ in (og̉in) 065

o.+ 1nı (oǵlını) 041, 098

o.+ 1 (og̉lı) 061

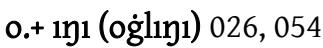

o.+ uy (ogluy) 109

o.+ una (og̉luna) 124

o.+ un1 (og̉lun1) 030

oḳ1- Çağırmak, davet etmek. ↔ oḳu-.

o.- $\mathrm{r} 040$

oḳu- 1. Çağırmak, davet etmek. ↔ oḳ1-.

o.- r 073

2. Okumak.

o.- dum 006

ol- 1. Meydana gelmek, vuku bulmak.

o.- masun 104

2. "Olmak, bulunmak, meydana gelmek" anlamında yardımcı fiil.

o.- a 066 


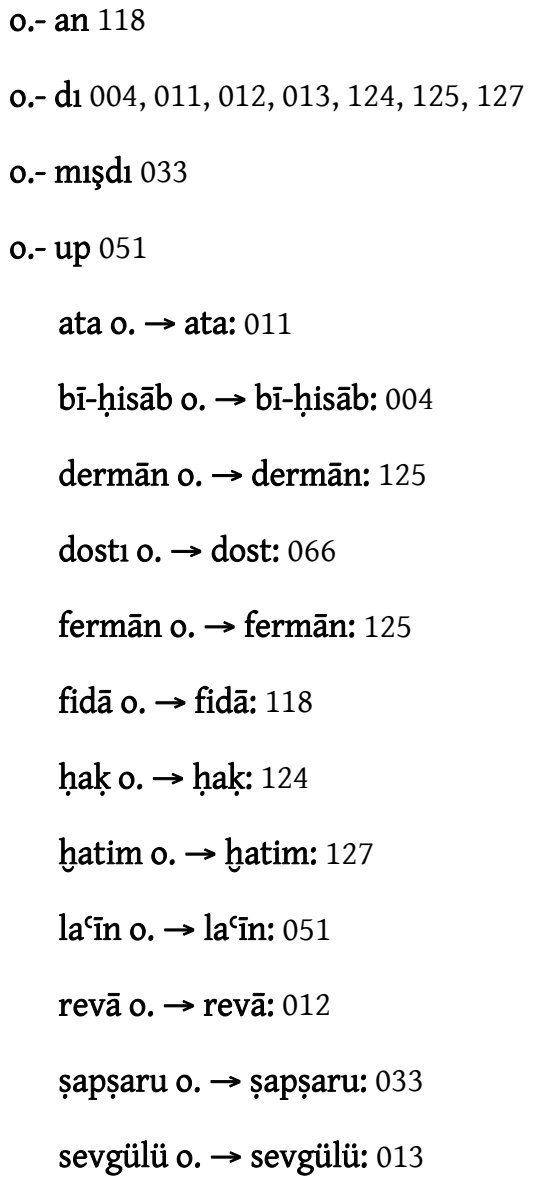

ög- Övmek.

$$
\text { ö.- er } 077
$$

öl- Ölmek, vefat etmek.

$$
\text { ö.- mege } 054
$$

öldür- Bir canlının hayatına son vermek, öldürmek. ö.- mege 074, 086

ö.- ür 080, 085

öp- Öpmek.

ö.- di 046

ör- 1. Yükselmek, çıkmak, belirmek.

ö.- ü țur- Ayağa kalkmak: 024, 025, 026, 033

2. Taş, tuğla vb. ile bir duvar yapmak.

ö.- erin 006

ötri -den dolayı, -in yüzünden, -in sebebiyle.

ö. 071

öyle Öyle, o şekilde, o biçimde.

ö. 054, 097

ö. it- Öyle yapmak, o şekilde yapmak: 097

\section{$\mathrm{P}$}

pāk (<F. pāk) Temiz.

$$
\text { p.- i dīn Dini temiz: } 087
$$

paşa Sayılan ve sevilen kimseler için kullanılan hitap sözü.

p. 116

pes (< F.pes) Şu hâlde, öyleyse, imdi.

p. 062

peyġāmber (< F. peyg்āmber) Allah tarafindan emirlerini kullarına bildirmekle görevlendirilmiş kimse, Tanrı elçisi, nebî, resul.

p. 078

pıçaḳ Bıçak. ↔ bıçak.

p. 124

p.+ 1112,126

pıçak çal- Bıçağı sürmek, bıçakla bir şeyi kesmeye çalışmak: 112, 124, 126

R

rabbü'l-celīl (<Ar. rabbü'l-celïl) Ulu Tanrı.

r. 114 
revā $(<\mathrm{F}$. revā) Layık, uygun, yerinde, münasip.

r. ol- Yerine gelmek: 012

rūḥ̣ (<Ar. rūḥ) Can, nefes, ruh.

r.+ ina 128

$\mathrm{S}$

sācat (<Ar. sā' at) Vakit, zaman, an.

s. 032

șaç Başı kaplayan kıllar, saç.

ș.+ 1n 038

ș.+ larını 044

șag் Să̆ taraf, sağ yön.

ṣ. 087

șağişla- Düşünmek.

s.̣. d 1010

șaḥrā (< Ar. șahrā̄) Çöl.

ș. 093

șaḳal Erkeklerde çene ve yanaklarda çıkan kılların bütünü, sakal.

Ș.+ 1084

șal- Sallamak, uzatmak.

ș.- am 104

el ṣ. $\rightarrow$ el: 104

șalavāt (< Ar.șalavāt) Hz. Muhammed'e ve onun soyundan gelenlere saygı ifade etmek için okunan "Allah'ım efendimiz Muhammed'e ve onun soyundan gelenlere salat ve selam olsun." anlamina gelen dua.

ș. 128

ș. vir-Sevap kazanmak için veya Hz. Muhammed'in ruhaniyetine sığınmak amacıyla salavat okumak: 002, 017, 049, 083, 127

șan- Öyle olduğunu düşünmek, zannetmek, öyle sanmak, öyle kabul etmek, farz etmek.

ș.- dıg 054 saya Sana.

s. $008,024,025,070,074,075,086,104$,

109,122

șapșaru (Yüz, ten, vücut için) Çok solgun, çok sararmiş.

ș. 033

șarın- (Sarık, kemer vb.ni) Üzerine dolamak, üzerine sarmak.

ș. 039

sen Sen (İkinci tekil şahıs zamiri).

s. $020,028,054,089,092,103,126$

s.+ den $071,085,105$

s.+ i 072, 073, 074, 082, 085, 086, 091

s.+ in $071,072,076$

s.+ misin 047

s. $+\sin 066$

s.+ üyle 048

sev- (Bir șey veya kimseye) Sevgi duymak, gönlünde ona karşı bir muhabbet beslemek, sevmek.

s.- dügümi 008, 022

s.- dügün 015, 020, 027

s.- dügüni 023

s.- en 123

s.- er 080

sevgili Sevgi duyulan, kendisine sevgi beslenen. sevgüli, sevgülü.

s. 122

sevgüli Sevgi duyulan, kendisine sevgi beslenen. $\leftrightarrow$ sevgili, sevgülü.

s. 016

sevgülü Sevgi duyulan, kendisine sevgi beslenen. sevgili, sevgüli.

s. ol- Sevgili olmak, kendisine sevgi beslenen kişi olmak: 013 
ș1- (Bir kimseyi) Darıltmak, kırmak.

ș.- yamaz 063

sözin ș. $\rightarrow$ söz: 063

șıg'- (Bir şey) Bütünüyle diğer bir şeyin içine girebilmek, sığmak.

s..- maya 123

șıga- Sıvamak, kıvırmak, toplamak.

ș.- di 042

șıra Birbiri ardınca veya yan yana düz ve doğru bir şekilde dizilmiş kimselerin veya şeylerin tamamı, dizi, saf.

șıra ș. Yan yana veya art arda dizilmiş sıralar şeklinde, saf saf: 021

söyle- (Anlatmak istediği şeyi) sözle bildirmek, söylemek.

s.- di $015,052,059,070$

s.- dügi 076

s.- $\mathrm{me} 067$

s.- megil 081

s.- $\sin 067$

söz 1. Söz, laf, kelam.

s. $+\mathrm{e} 002$

s.+ i 024, 036, 061, 075

s.t in 056,063

s.+ ler 076

s.+ in ș1- Sözünü kırmak: 063

2. Bir şeyi yapacağını veya yapmayacağını kesin olarak bildirme, vaat, taahhüt.

s.+ ine 019

s.+ ine țur- Sözünü tutmak: 019

șuç Suç, günah, kabahat.

s.+ in 060

ș.+ um 079

ș. it- Suç işlemek, kabahat işlemek: 116 sulțān (< Ar. sulțān) Hükümdar, padişah, sultan.

s.- 1 kerem Cömertlik sultanı: 005

sücūd (< Ar. sucūd) Secde etme, secde.

s. ḳl- Secde etmek: 003

sülük (Mecazi anlamda) Yapışık, sırnaşık, yaslanmiş.

s. 044

sür- (Birine veya bir yere doğru) İtmek, uzatmak.

s. 100

Ş

şāh (< F. şāh-şeh) Padişah, hükümdar, şah.

ḩalilullāh-1 ş.- 1 muhterem $\rightarrow$ h halīlullāh: 005

şefā'at (< Ar. şefă'at) Bir suçun bağışlanması veya bir isteğin yerine getirilmesi için aracı olma.

ş. 099

şeyțān $(<$ Ar. şeyțān < İbr. șătāan) Şeytan, iblis.

ş.+ dan 083

şimdi $(<s ̧ u+i m d i)$ Şimdi, şu an.

ş. 057,071

şöyle (<şu + eyle) Öyle, şu biçimde, şuna benzer, şunun gibi, şu șekilde.

ş. $006,016,087$

ş. it- Böyle yapmak: 087

tā (<F. tā) Bir şeyin bulunduğu, başladığı veya sona erdiği yeri yahut zamanı anlatırken söze mübalağa katar. Genellikle dek, değin, kadar, beri vb. edatlarla kullanılır.

t. $011,125,126$

tamām $(<$ Ar. temām $\quad$ Bitme, tamamlanma, sona erme.

t. eyle- Bitirmek, tamamlamak: 121

t. işle- Bitirmek, tamamlamak: 022, 113

țay Güneş doğmadan önceki alaca karanlık, fecir. 


\section{ț.+ layucaḳ 017}

tayrı Tanrı, Allah.

t. 065,092

t.+ dan 009

t.+ nuy 032, 094

țara- Tarakla tellerini birbirinden ayırmak, karışılığını gidermek; düzeltmek; taramak.

ț. 038

ț.- di 044

ț.- mag̉a 043

țarak Saç, sakal ve tüylü şeylerin kıllarını birbirinden ayırmaya ve karışıklığını gidermeye yarayan dişli alet, tarak.

ț. 043

țaş Taş.

ț. 082

t..+ a 112,116

t..+ 1112,113

ț.+ $\ln 092$

țaşla- Üzerine taş atmak, taşa tutmak.

t..- dın 053

țatlu İnsanın üzerinde iyi etki bırakan, hoşa giden, rahatlatan, yumuşak.

ț. 056

tecalā (< Ar. te'ālā) "Şanı yüce olsun" anlamında olup Allah, Hak, Tanrı kelimelerinden sonra kullanilır.

ḥak t. $\rightarrow$ ḥaḳ: 003

tebdil (< Ar. tebdil) Değiştirme, değiştirilme, başka şekle sokma.

t. $+\mathrm{i} 120$

telbīs (< Ar. telbis) Doğrucu görünerek aldatma, gerçeği başka türlü gösterme, oyun, hile.

t. idi 088 terk (< Ar. terk) Bırakma.

t. it-Brrakmak, vazgeçmek: 020, 095, 097

tez (< F. tīz) Çabuk, hemen.

t. 118

tīzrek (<F. tìz + T. -rek) Derhal, çabucak.

t. 048

țokın- Dokunmak, değmek, temas etmek.

ț.- a 104

țol- (Bir duygu insanın içini, gönlünü...) Kaplamak, sarmak.

ț.- up 051

țon Elbise.

t..+ lar1 039

ț.+ larını 045

țur-1. Kalkmak, ayağa kalkmak.

ț.- d 1042

ț.- $\dot{g} 1030$

ț.- ur 017

2. (Bir yerde) Durmak, kalmak, bulunmak, beklemek.

ț.- magil 028

3. Birakmamak, terk etmemek.

ț.- maz misin 020

ț.- maduy 019

kavline ț. $\rightarrow$ ḳavl: 020

sözine ț. $\rightarrow$ söz: 019

4. Yardımcı fiil olarak süreklilik fiili yapar.

örü ț. $\rightarrow$ ör-: 024, 025, 026, 033

țut-(Verdiği söz, ettiği yemin vb. için) yerine getirmek, gereğini yapmak, gerçekleştirmek.

ț.- a 094

ț.- mak 032

ț.- maya 062 


\section{buyruk ț. $\rightarrow$ buyruk: 062, 094}

țuy- İşitmek, duymak.

ț.- di 072

\section{$\mathrm{U}$}

ur-1. (Elini veya elindeki bir şeyi bir yere) Hızla indirmek, hızla çarpmak.

u.- d 083

u.- dum 087

2. Sürmek, dokundurmak.

u.- di 046

urucı Vuran, kesen.

$$
\text { yol u. } \rightarrow \text { yol: } 066
$$

uṣlu Akılll, söz dinleyen, edepli.

u. 091

uş Şimdi, işte.

u. $073,074,086$

uy- (Kişi için) Davranışlarını o kimseye göre ayarlamak, ona uygun davranmak, onun yolunu izlemek, bağlı kalmak, tabi olmak.

u.- a 091

uyan- Uyku durumundan çıkmak, uyanmak.

u. 024

u.- d 029

uyḩu Uyku. $\leftrightarrow$ uyḳu.

u.+ dan 033,034

u.+ ya var- Uykuya dalmak, uyumak: 007

uyḳu Uyku. $\leftrightarrow$ uyḩu.

u. + dan 029

u. gel- Uyku bastırmak, uykusu gelmek: 014

uyu- Uyku durumunda bulunmak, uyumak.

u.- d 1014

u.- madi 010
$\ddot{\mathrm{u}}(<\mathrm{F} . \mathrm{u})$ "Ve" bağlacının sessiz harfle biten kelimelerden sonraki okunuşu.

dün ü. gün $\rightarrow$ dün: 011

ümiz $(<$ F. umìd / umiz $) \quad$ Arzu edilen, olması istenen bir şeye duyulan beklenti, umut, ümit.

ü.+ im 047

ünde- Çağırmak, seslenmek.

ü.- r 073

\section{V}

var-1. Gitmek, yürümek.

v. 081

v.- di 054, 055

v.- mag்1l 075

v.- up $017,049,092$

2. Bir hâle girmek, o hâl üzere olmak, o hâle dalmak.

v.- maz idi 007

uyhhuya v. $\rightarrow$ uyḩu: 007

var Mevcut olan, bulunan, tamam, hepsi.

v.+ - -1d1 016, 021

vașiyyet (< Ar. vașiyyet) Bir kimsenin sözlü veya yazılı olarak bildirdiği, ölümünden sonra arkasından yapılmasını istediği şey; vasiyet.

v. ḳl- Öldükten sonra ne yapılmasını istediğini bildirmek: 106

vāz (<F. vāz) Bırakma, terk.

v. 047

ve's-selām (< Ar. ve's-selām) “isşte o kadar, son söz bu” anlamında sözü kısa kesmek için kullanilır.

v. 127

vir- 1. Birisine eriştirmek, iletmek, alması için ona doğru uzatmak.

v.- di 110 
2. (Bir şeyi karşılık beklemeden birine) B1rakmak, bağışlamak.

v.- $\operatorname{dim} 025$

V.- gil 008, 025

3. Göndermek.

v.- di 073

4. Anlamca kaynaşmı̧̧-deyimleşmiş birleşik fiiller yapar.

v. $017,049,083,127,128$

V.- elüm 002

V.- medün 019

ḳurbān v. $\rightarrow$ kurbān: 019

șalavāt v. $\rightarrow$ șalavāt: 002, 017, 049, 083, 127, 128

viribi- Göndermek.

v.- düy 054

vücūd (< Ar. vucūd) İnsan veya hayvan gövdesi, beden.

v. ḳ1- Vücut vermek, vücut meydana getirmek: 003

Y

ya Veya.

у. 096

yā (< Ar. yā) Ey (Seslenme ünlemi).

y. $020,027,114,116,120$

yak- Acıtmak, yakmak.

y.- mayın 101

yüregini y. $\rightarrow$ yürek: 101

yalvar- Dilemek, istemek, yalvarmak, dileğinin yapilmasını israrla istemek.

y.- di 011

yan Kat, huzur, nezd.

y.+ 1na 052

yan- Yanmak, tutuşmak, alev almak. y.- am 104

oda y. $\rightarrow$ od: 104

yarak Hazırlık.

y. ḳıl- Hazırlık yapmak: 043

yarat- (Allah) Yoktan var etmek, halketmek.

y.- an 050

yarın Ahret günü.

y. 104

yat- Uyumak, yatmak.

y.- di 030

y.- ursin 024

yavız Fena, kötü. ↔ yavuz.

y. 090

yavuz Fena, kötü. $\leftrightarrow$ yavız.

y. 051, 064, 068, 069

yer Ayakla basılan, ayakların altında bulunan yüzey, zemin.

y.+ dedür 099

y.+ e 078, 100

y.+ ine gel- Yapılmak, gerçekleştirilmek, olmak: 120

y.+ ine getür- İstenileni, gerekeni yapmak: 026

yet- Götürmek.

$$
\text { y.- er (yeder) } 017
$$

yetmiş Yetmiş sayısı.

$$
\text { y. 031, 098, } 110
$$

yigrek Çok iyi, daha iyi.

y. 036

yine Yine, bir daha, tekrar, gene, yeniden.

y. 018, 019, 023, 030

yol Yol, gidilen yer, reh.

y. 036,066 
y.+ a 048

y.+ dan 090

y.+ 1na 093

y. gözle- Uzaktan gelmesi muhtemel bir yolcuyu beklemek: 036

y. urucı Yol kesen: 066

y.+ a baḳdur-Yola baktırmak, bekletmek: 048

y.+ dan çıkar- Doğru yoldan ayırmak, kötülüğe saptırmak: 090

y.+ ına düş- Yola çıkmak, yolculuğa başlamak: 093

yu- Y1kamak, temizlemek.

y. 038

y.- ġ1: 028, 030

ḳana y. $\rightarrow$ ḳan: 028, 030

yürek Kalp, gönül, yürek.

y.+ ini (yüregini) 101

y.+ ini yạ:: Ac1 vermek, üzmek: 101

yüri- Yürümek, gitmek.

y. 081

yüz (1) Yüz sayısı.

y. $016,018,021$

yüz (2) Surat, çehre.

y.+ in 046, 055, 056, 096

y.+ ine 046

y.+ ümi 100

y.+ üne 101

y. yüze Karşı karşıya, yüzleri birbirine dönük olarak: 099

Z

zaḥmet (< Ar. zaḥmet) Sıkıntı, güçlük, zorluk, eziyet.

z.+ le 057 zamān (< Ar. zemān) Zaman, vakit, süre.

z. 001

zīrā (< F. zīrā) Çünkü, şundan dolayı.

z. 063,072

\subsection{Arapça İbareler Dizini}

fācilātün fācilātün fā'ilāt (< Ar. aruz ölçüsü) Aruz ölçüsünün Remel bahrinin kalıplarındandır. Türk edebiyatında en çok kullanılan kalıplardandır. Pek çok mesnevi bu kalıpla yazılmiştır.

f. 128

len tenālū'l-birra hattā tunfikū (Âl-i İmrân suresi, 92. ayetten) "Sevdiğiniz şeylerden Allah yolunda harcamadıkça iyiliğe asla erişemezsiniz." 


\section{Eserin Söz Varlığının İncelenmesi}

Bu bölümde Destân-ı İsmâ̂ll mesnevisi üzerine yapılan dizinden hareketle söz varlığ incelemesi yapılacaktır. İnceleme şu üç aşamadan oluşacaktır: 1. Dizinde yer alan madde başlarının alfabetik olarak dağılımı 2. Dizinde yer alan madde başlarının ait olduğu dillere göre dağılımı 3. Dizindeki madde başlarının kelime kategorisine (isim/fiil) göre dağılımı.

\subsection{Madde Başlarının Alfabetik Dağılımı ve Sayısal İstatistikleri}

\begin{tabular}{|c|c|c|}
\hline & \multicolumn{2}{|c|}{ Madde Başı } \\
\hline Ön Ses & Sayı & Oran \% \\
\hline a & 33 & 8.43 \\
\hline b & 46 & 11.76 \\
\hline c & 7 & 1.79 \\
\hline ç & 9 & 2.30 \\
\hline$d$ & 32 & 8.18 \\
\hline e & 13 & 3.32 \\
\hline$f$ & 3 & 0.76 \\
\hline$g$ & 23 & 5.88 \\
\hline h & 19 & 4.85 \\
\hline 1 & 1 & 0.25 \\
\hline i & 18 & 4.60 \\
\hline k & 40 & 10.23 \\
\hline 1 & 2 & 0.51 \\
\hline $\mathrm{m}$ & 9 & 2.30 \\
\hline $\mathrm{n}$ & 12 & 3.06 \\
\hline 0 & 9 & 2.30 \\
\hline ö & 7 & 1.79 \\
\hline $\mathrm{p}$ & 5 & 1.27 \\
\hline$r$ & 3 & 0.76 \\
\hline $\mathbf{s}$ & 28 & 7.16 \\
\hline ş & 5 & 1.27 \\
\hline$t$ & 21 & 5.37 \\
\hline $\mathrm{u}$ & 9 & 2.30 \\
\hline$\ddot{\mathrm{u}}$ & 3 & 0.76 \\
\hline $\mathbf{v}$ & 8 & 2.04 \\
\hline$y$ & 23 & 5.88 \\
\hline z & 3 & 0.76 \\
\hline Toplam & 391 & $\% 100$ \\
\hline
\end{tabular}


6.2. Madde Başlarının Ait Olduğu Dillere Göre Dağılımı

\begin{tabular}{||c|c|c||}
\hline & Madde Baş1 & \\
\hline \hline Dil & Say1 & Oran \% \\
\hline \hline Türkçe & 270 & 69.05 \\
\hline Arapça & 76 & 19.43 \\
\hline \hline Farsça & 35 & 8.95 \\
\hline \hline Farsça + Arapça & 2 & 0.51 \\
\hline Farsça + Türkçe & 2 & 0.51 \\
\hline \hline Kişi Adlar1 & 6 & 1.53 \\
\hline \hline Toplam & 391 & \%100 \\
\hline \hline
\end{tabular}

6.3. Madde Başlarının İsim / Fiil Olma Durumuna Göre Dağılımı

\begin{tabular}{||c|c||c|}
\hline & Madde Başı & \\
\hline \hline Kelime Türü & Say1 & Oran \% \\
\hline \hline İsim & 275 & 70.33 \\
\hline \hline Fiil & 116 & 29.66 \\
\hline \hline Toplam & 391 & \%100 \\
\hline
\end{tabular}

\section{Sonuç}

Aksaraylı Îsâ, XIV. yüzyılda veya buna yakın bir dönemde yaşamış meddah bir şairdir. Adından anlaşılacağı üzere Konya ve Aksaray çevresinde yaşamıştır. Onun Beylikler Dönemi'nde ve özellikle Karamanoğulları Beyliği Dönemi'nde (1250-1457) yaşadığını düşünmek hiç de yanlış olmayacaktır. Eserlerinden anlaşıldığı kadarıyla Arapça ve Farsçaya vâkıf olacak derecede iyi bir eğitim almıştır. Sade ve akıcı bir halk Türkçesi ile yazdığı eserleri şehir, köy ve kasabalarda icra etmiştir. Beylikler ve Osmanlı Devleti'nin Kuruluş Dönemi'nde yaşayan pek çok şair gibi İslam dini ile ilgili dinî ve ahlaki çizgide eserler yazmıştır. Bu dönemdeki pek çok meddah geniş halk kitlelerine İslam dini ile ilgili bazı basit bilgileri bu eserler yoluyla aktarmışlardır. Bu çalışmada, Aksaraylı Îsâ’nın Destân-ı İsmâ’̂̉l adlı mesnevisi ele alınmış ve incelenmiştir. Eser ve yazarla ilgili ulaştığımız bazı sonuçlar şu şekildedir:

1. Hz. İbrahim'in oğlu İsmail'i Allah yolunda kurban etmek istemesi olayının ana kaynağı Tevrat'tır. Yahudi ve Hristiyan kaynakları burada kesilmek istenen kişinin İshak olduğunu kabul ederler. İslam kaynaklarında bu konuyla ilgili her iki görüş de vardır ancak Türk edebiyatı ve Türk düşünce dünyasında bu kişinin Hz. İsmail olduğu düşüncesi öne çıkmıştır. 
2. Aksaraylı Îsâ'nın Destân-ı İsmâ̂̀l adlı eserinin Türk edebiyatında bu konuda yazılmış ilk eser olması büyük olasılıktır. Kaynaklar bu konuda Abdülvâsi Çelebi'nin (öl. 1414-15) Halilname adlı eserini ilk eser kabul etmektedirler. Ancak Aksaraylı Îsâ, çok büyük ihtimalle XIV. yüzyılda ve Karamanoğulları Beyliği Dönemi'nde yaşamıştır.

3. Aksaraylı Îsâ, bir eserinde Mevlâna ve oğlu Sultan Veled'i övmektedir. Bu durum onun Mevlevî çevrelerle yakından ilgili olduğunu göstermektedir.

4. Aksaraylı Îsâ'nın Destân-ı İsmâ’̂̂l mesnevisnde anlattığı konu Kur'an ve İslami literatüre uygundur. Şair, İslam kaynaklarından aldığı bu konuyu mesnevi nazım şeklinde hikâyeleştirmiştir.

5. Eserde, Hz. İbrahim'in Allah yolunda en sevdiği varlık olan oğlu İsmail'den vazgeçmesi ve onu Allah yolunda Kurban etmek istemesi anlatılmaktadır. Eserdeki ana mesaj Kur'an'dan alınan bir surede de açıkça ortaya konmuştur: “Sevdiğiniz şeylerden Allah yolunda harcamadıkça iyiliğe asla erişemezsiniz." (Âl-i İmrân suresi 92). Hz. İbrahim, durumu Hz. İsmail'e bildirdiğinde kendisi bu emre karşı tam bir teslimiyet göstermiştir.

6. Aksaraylı Îsâ'nın Destân-ı İsmâ̂̉ mesnevisinin çalıştığımız nüshası (06 Mil Yz A 6823/5) 128 beyitten oluşmaktadır. Tespit ettiğimiz nüshalar arasında en çok beyit barindıran nüsha budur.

7. Eserin çalıştığımız nüshasında yazar adı geçmemektedir. Yazar adı Vasfi Mahir Kocatürk'ün özel yazmaları arasında bulunan ve Ankara Millî Kütüphaneye verilen 06 Mil Yz A 3881/5 nüshasında geçmektedir.

8. Kur'an'da Hz. İsmail'in adı açıkça geçmemektedir ve annesi Hacer'den de hiç bahsedilmemektedir. Hz. İsmail ile ilgili hadislerde de oldukça az bilgi vardır. Bu durumda Aksaraylı Îsâ, eserini oluştururken gelenekten, bu konudaki başka eserlerden ve diğer İslami kaynaklardan yararlanmış olmalıdır. Bu da yazarın Arapça, Farsça gibi yabancı dillere vâkıf olduğunu ve iyi bir eğitim aldığını gösterir.

9. Eserde yer ve zaman kavramları belirsizdir. İslam kaynakları bu olayın Mekke'de Kâbe'ye yakın bir dağda gerçekleştiğini belirtmektedir. Yahudi geleneğinde ise Moriyya diyarında bir dağda bu olay gerçekleşmiştir. Belirtilen bu bölgenin tam olarak neresi olduğu belli değildir. Zaman kavramı ise hiç belli değildir. Hz. İbrahim'in MÖ 2200-2000 arasında bir dönemde yaşadığı rivayet edilmektedir. Bu olay, Hz. İbrahim'in yaşlılık döneminde (86 yaşından sonra) gerçekleşmiştir.

10. Eserin dili Eski Anadolu Türkçesi dil özellikleri taşımaktadır. Ancak eserin geç dönemde istinsah edilmesinden dolayı sonraki dönemlere ait dil özellikleri de esere 
etki etmiştir. Böylelikle eser dil özellikleri bakımından çok katmanlı bir yapı arz etmektedir. Bu dil özellikleri Eserin Dili Üzerine Notlar kısmında incelenmiştir.

11. Eserin söz varlığının 275'i (\%70.33) isim ve isim soylu kelimelerden, 116's1 (\%29.66) fiillerden oluşmaktadır.

12. Eserin söz varllğı incelendiğinde toplam madde başları sayısı 391'dir. Eserdeki Türkçe kelimelerin sayısı 270 (\%69,05), Arapça kelimelerin sayısı 76 (\%19,43), Farsça kelimelerin sayısı $35(\% 8,95)$ şeklindedir. Eserde 6 adet de $(\% 1,53)$ kişi adı geçmektedir. Eserde Türkçe kelimelerin bu kadar çok olması eserin halk için yazıldığını göstermektedir. Bu tür halk hikâyeleri halkın kullandığı son derece sade ve akıcı bir Türkçe ile yazılmaktadır. Eserde var olan yabancı kelimeler de günlük hayatta kullanılan son derece basit ve genelde İslam dini ile ilgili kelimelerdir. Bu nedenle bu eserler Türk dili, edebiyatı ve kültürü açısından son derece önemli eserlerdir.

\section{Kısaltma ve İşaretler}

\subsection{Kisaltmalar}

Ar. = Arapça.

bk. = Bakınız.

Çev. $=$ Çeviren .

$\mathrm{F} .=$ Farsça.

H. $=$ Hicrî.

Haz. = Hazırlayan .

k.a. $=$ kişi adı.

M. = Miladi.

$\mathrm{vb} .=\mathrm{Ve}$ benzeri.

$\mathrm{vd} .=$ ve diğerleri.

\section{2. İşaretler}

[ ] Beyitlerin çevirisi köşeli parantez içerisinde gösterilmiştir.

(?) Şüphe belirtir.

( ) Çeviride fazladan eklenen kelimeleri gösterir.

< Kelimenin kaynağını gösterir.

> Kelimenin sonraki şeklini gösterir. 
+ $\quad$ 1. İsim tabanına gelen ek 2. Birleşik kelimelerin birleşimini gösterir.

- $\quad$ Fiil tabanına gelen işaret.

/ Bir kelimenin farklı şekillerini gösterir.

// Farklı türden örnekler arasındaki geçişi gösterir.

$\rightarrow$ Bakınız.

$\leftrightarrow \quad$ Karşılaştırınız.

\section{Kaynakça}

AKALIN, Ş. H. vd. (2011). Yazım Kılavuzu, Ankara: Türk Dil Kurumu Yayınları.

AKAR, M. (1987). Türk Edebiyatında Manzum Miraçnameler, Ankara: Kültür Bakanlığ1 Yayınları.

AYVERDİ, İ. (2006). Misalli Büyük Türkçe Sözlük I-III, İstanbul: Kubbealtı Yayınları.

BÜcÜK, T. (2013). İsmail Malati'nin Destan-1 İsmail Adlı Eseri (Transkripsiyonlu Metin, Dil Bilgisi), Selçuk Üniversitesi, Sosyal Bilimler Enstitüsü, Konya. (Yayımlanmamış Yüksek Lisans Tezi)

CLAUSON, Sir G. (1972). An Etymological Dictionary of Pre-Thirteenth Century Turkish, Oxford: Oxford University Press.

ÇAĞBAYIR, Y. (2007). Orhun Yazıtlarından Günümüze Türkiye Türkçesinin Söz Varlığı, Ötüken Türkçe Sözlük I-V, İstanbul: Ötüken Yayınları.

Demirci, Ü. Ö. \& Ş. KorKMAz (2008). Şeyyâd Hamza, Yûsuf ve Zelîhâ (Giriş-Metin-Günümüz Türkçesine Aktarma-Dizin ve Sözlük-Tıpkıbasım), İstanbul: Kaknüs Yayınları.

DENY, J. (2012). Türk Dil Bilgisi, İstanbul: Kabalcı Yayınevi.

DevellioĞLu, F. (2007). Osmanlıca-Türkçe Ansiklopedik Sözlük, Ankara: Aydın Kitabevi.

Dilçin, C. (1991). Mes'ûd Bin Ahmed, Süheyl ü Nev-Bahâr (İnceleme-Metin-Sözlük), Ankara: Türk Dil Kurumu Yayınları.

EdísKUn, H. (2007). Türk Dil Bilgisi (Sesbilgisi-Biçimbilgisi-Cümlebilgisi), İstanbul: Remzi Kitabevi.

ERGiN, M. (1993). Türk Dil Bilgisi, İstanbul: Bayrak Yayınları.

GÜLDAŞ, A. (1996). Abdülvasi Çelebi: Halilname, Ankara: Kültür Bakanlığı Yayınları.

GÜLSEvin, G.\& E. Boz (2007). Eski Anadolu Türkçesi, Ankara: Gazi Kitabevi.

GüLSEvin, G. (2007). Eski Anadolu Türkçesinde Ekler, Ankara: Türk Dil Kurumu Yayınları. 
HARMAN, Ö. F. (2000). “İbrâhim”, Türkiye Diyanet Vakfi İslâm Ansiklopedisi, 21, Türk Diyanet Vakfı Yayınları, Ankara: 266-272.

HARMAN, Ö. F. (2001). “İsmâil”, Türkiye Diyanet Vakfı İslâm Ansiklopedisi, 23, Türk Diyanet Vakfı Yayınları, Ankara: 76-80.

İzmirLi, İ. H. (1977). Kur’ân-1 Kerim Türkçe Anlamı (Ma'âni-i Kur’ân), İstanbul: Eren Yayınları.

KANAR, M. (2011). Eski Anadolu Türkçesi Sözlüğü, İstanbul: Say Yayınları.

KARAMAN, H. et al. (2007). Kur'ân-1 Kerîm ve Açıklamalı Meâli, Ankara: Türkiye Diyanet Vakfi Yayınları.

KAVRUK, H. (1999). Eski Türk Edebiyatı'nda Mensûr Hikâyeler, İstanbul: Milli Eğitim Bakanlığı Yayınları.

KoCASAVAŞ, Y. (2004). Türkçede Şahıs Zamirleri, Ankara: Türk Dil Kurumu Yayınları.

KoCATÜRK, V. M. (2016). Büyük Türk Edebiyatı Tarihi, 3. Baskı, İstanbul: İkü Yayınevi.

KoRKMAz, [Bulut] T. (2017). Arzu ile Kanber Hikâyesi [Milli Kütüphane Nüshasi 06 Mil Yz A 8618 ve Konya Nüshası 42 Kon 1882/2], (İnceleme-Metin-Çeviri-Dizin ve Tıpkıbasım), Marmara Üniversitesi, Türkiyat Araştırmaları Enstitüsü, İstanbul. (Yayımlanmamış Doktora Tezi)

KorkmaZ, Ş. \& T. Korkmaz Bulut (2019). “Eski Edebiyatımızda Hırsızlık Konulu Mensur Bir Hikâye: Hikâyet-i Uğru Abbâs”, Hırsızlık Kitabı, Ed. E. GÜRSOY-NASKALİ, Kitabevi Yayınları, İstanbul: 467-478.

KoRKMAZ, Ş. (2012). Eski Anadolu Türkçesine Ait Bir Manzum Hikâye Mecmuası (İnceleme-Metin-Çeviri-Dizin ve Tıpkıbasım), Marmara Üniversitesi, Türkiyat Araştırmaları Enstitüsü, İstanbul. (Yayımlanmamış Doktora Tezi)

KorKMAZ, Ş. (2020). "Eski Anadolu Türkçesi Dönemine Ait Bir Hikâye: Aksaraylı Îsâ: Hikâyet-i Şuhmâ [06 Mil Yz A 6823/2]”, Journal of Old Turkic Studies, 4/1: 98-151.

KoRKMAZ, Z. (2007). Türkiye Türkçesi Grameri (Şekil Bilgisi), Ankara: Türk Dil Kurumu Yayınları.

KoRKMAZ, Z. (2011). Türkçede Eklerin Kullanılış Şekilleri ve Ek Kalıplaşması Olayları, Ankara: Türk Dil Kurumu Yayınları.

Örnekleriyle Türkçe Sözlük I-IV (1995). Ankara: Millî Eğitim Bakanlığı Yayınları.

ÖzAlP, N. A. (2014). Hikâye-i Mevlidi'n-Nebi (Mevlid Hikâyeleri), İstanbul: Büyüyen Ay Yayınları.

ÖZKAN, M. (2000). Türk Dilinin Gelişme Alanları ve Eski Anadolu Türkçesi, İstanbul: Filiz Kitabevi. 
SARI, M. \& V. BAlKAn (2000). “Kazim Meçi'nin Karaçayca “Ak Koçhar” (İsmail) Kıssası”, Türk Dünyası Dil ve Edebiyat Dergisi, 9: 184-201.

StEINGASS, F. J. (1975). A Comprehensive Persian-English Dictionary, Beirut: Librairie du Liban Publishers.

Şemseddin Sâmi (1985-1986). Temel Türkçe Sözlük I-III (Sadeleştirilmiş ve Genişletilmiş Kâmûs-1 Türkî), İstanbul: Tercüman Gazetesi Yayınları.

TIETZE, A. (2002). Tarihi ve Etimolojik Türkiye Türkçesi Lugatı I: A-E, İstanbul-Wien: Simurg Yayınları.

TímURTAş, F. K. (1994). Eski Türkiye Türkçesi (Gramer-Metin-Sözlük), İstanbul: Enderun Kitabevi.

Türkiye'de Halk Ağzından Derleme Sözlüğü I-XII (1993). 2. Baskı, Ankara: Türk Dil Kurumu Yayınları.

UzUn, M. (2000). “İbrâhim (Türk Edebiyatı)”, Türkiye Diyanet Vakfı İslâm Ansiklopedisi, 21, Türk Diyanet Vakfi Yayınları, Ankara: 272-273.

UzUn, M. (2001). “İsmâil (Türk Edebiyatı)”, Türkiye Diyanet Vakf1 İslâm Ansiklopedisi, 23, Türk Diyanet Vakfı Yayınları, Ankara: 80-82.

WENSINCK, A. J. (1967a). “İbrâhim”, İslâm Ansiklopedisi, 5/II, Milli Eğitim Bakanlığı Yayınları, Ankara: 878-879.

WensincK, A. J. (1967b). “İsmail”, İslâm Ansiklopedisi, 5/II, Milli Eğitim Bakanlığı Yayınları, Ankara: 1110-1111.

XIII. Yüzyıldan Beri Türkiye Türkçesiyle Yazılmış Kitaplardan Toplanan Tanıklarıyla Tarama Sözlüğü I-VIII (1996). 2. Baskı, Ankara: Türk Dil Kurumu Yayınları. 


\section{I(O)}

TIPKIBASIM

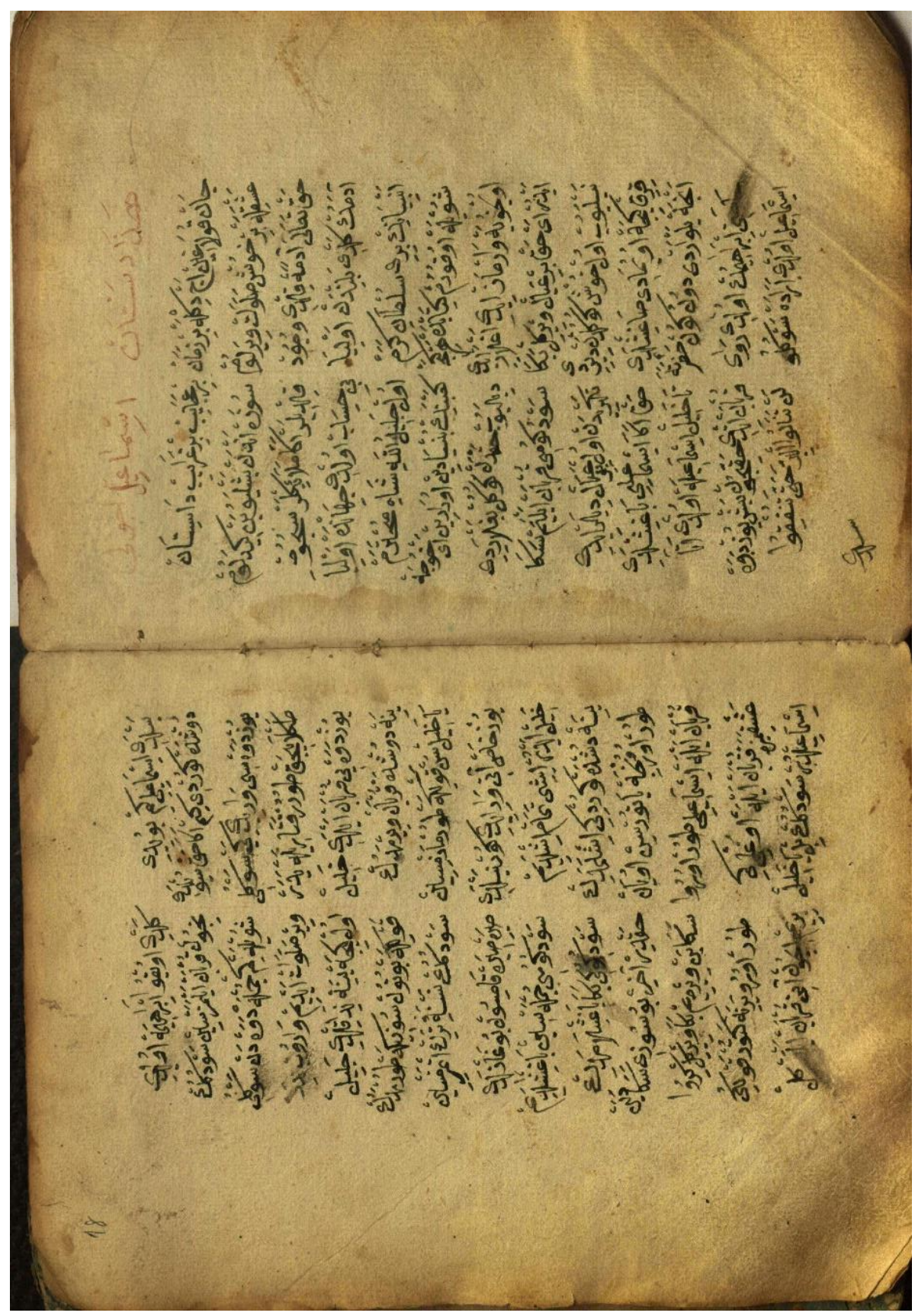

Millî Kütüphane 06 Mil Yz A 6823/5, 17b-18a 


\section{J(O)}

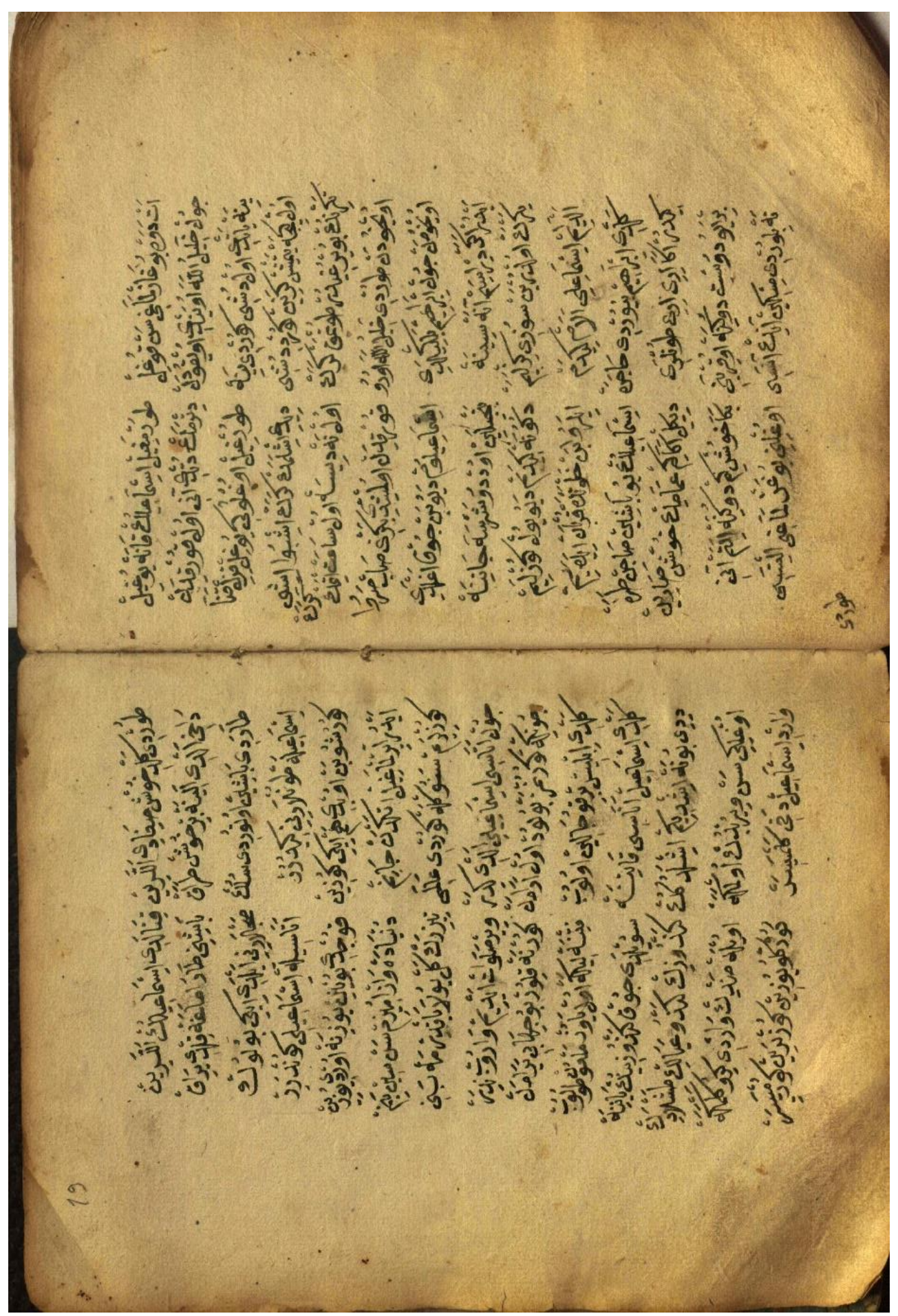

Millî Kütüphane 06 Mil Yz A 6823/5, 18b-19a 


\section{J(O)}

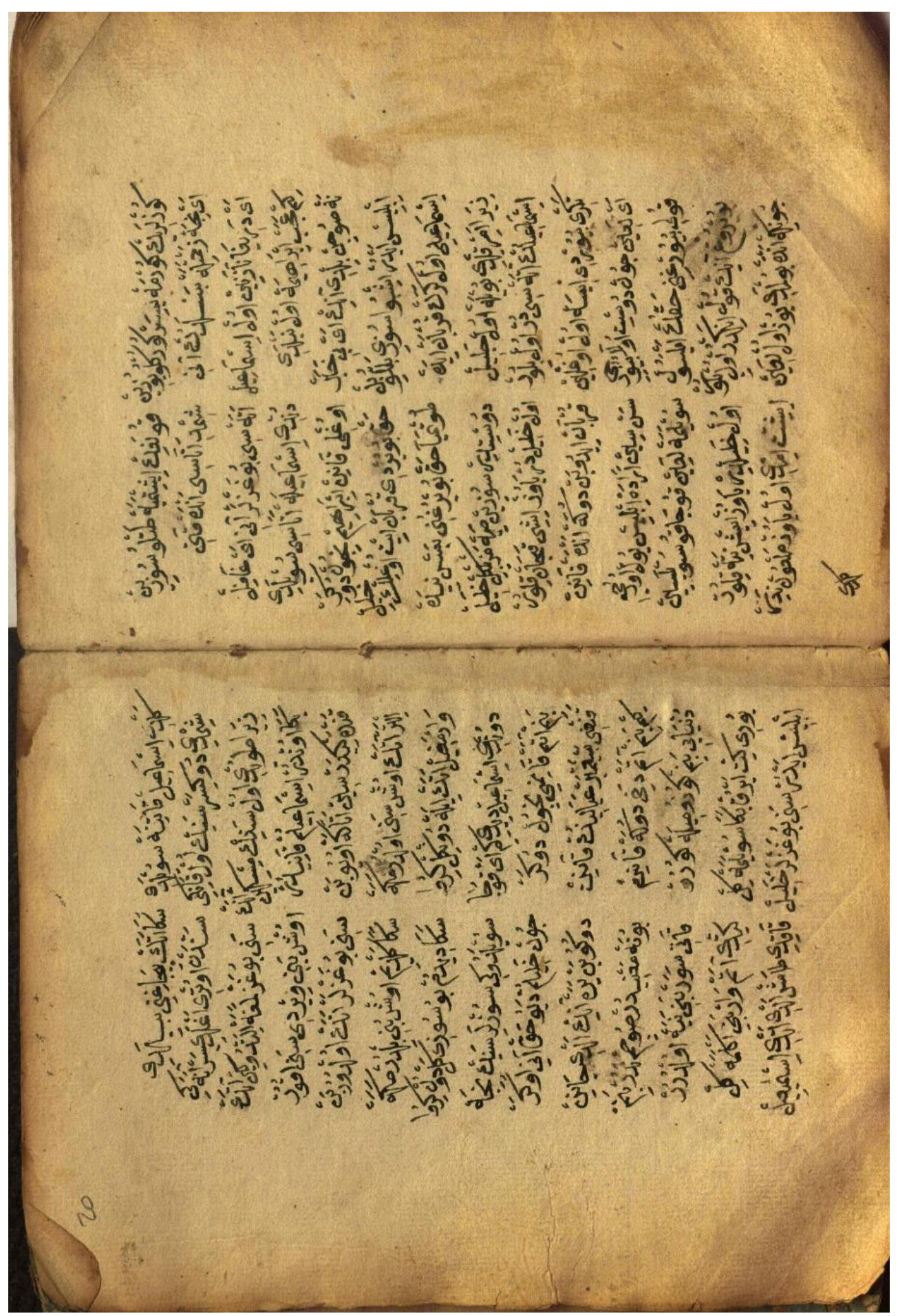

Millî Kütüphane 06 Mil Yz A 6823/5, 19b-20a 


\section{J(O)}

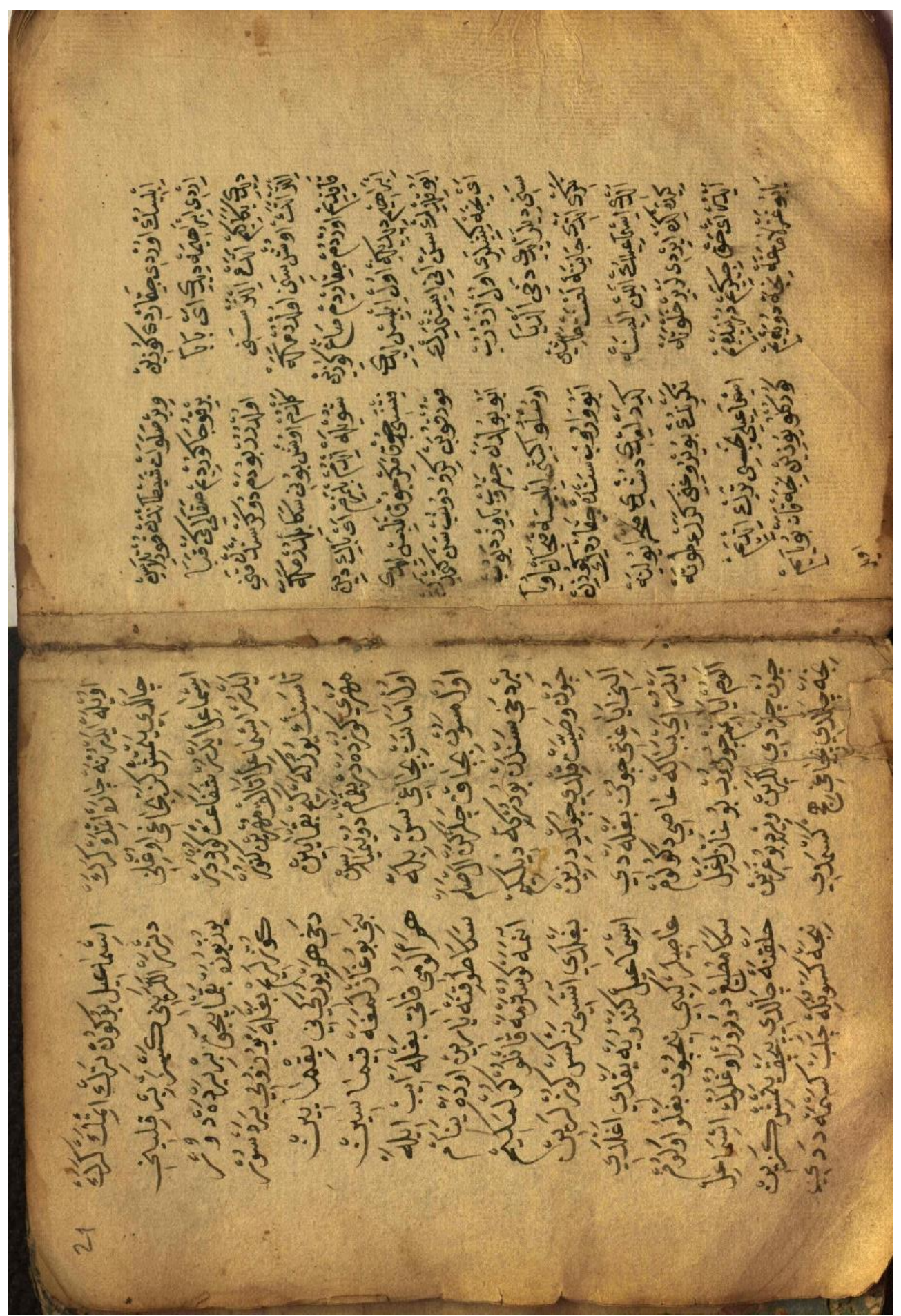

Millî Kütüphane 06 Mil Yz A 6823/5, 20b-21a 


\section{$J(\Theta)$}

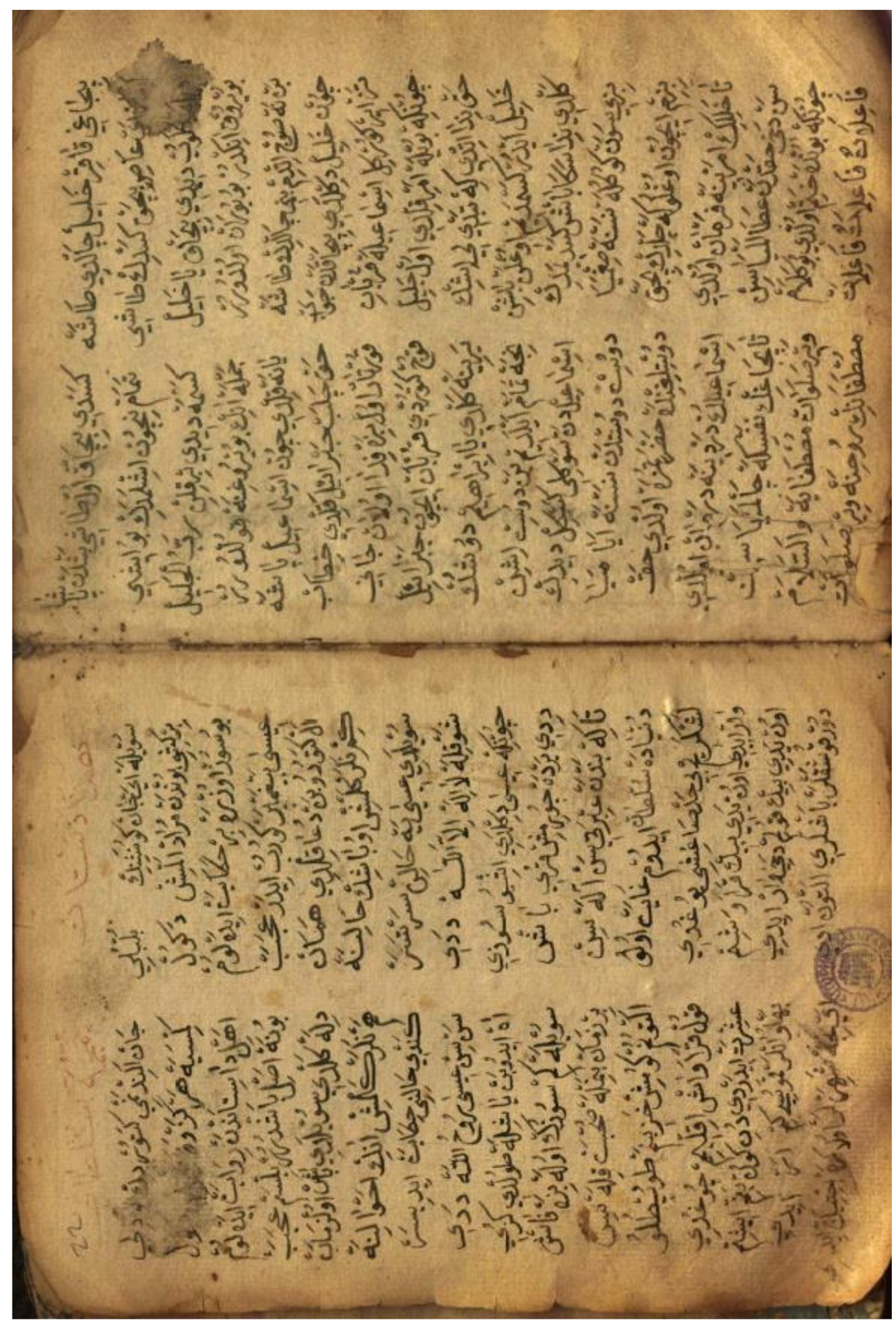

Millî Kütüphane 06 Mil Yz A 6823/5, 21b-22a 